GEOHYDROLOGY AND 1985 WATER WITHDRAWALS OF THE

AQUIFER SYSTEMS IN SOUTHWEST FLORIDA, WITH

EMPHASIS ON THE INTERMEDIATE AQUIFER SYSTEM

By A.D. Duerr, J.D. Hunn, B.R. Lewelling, and J.T. Trommer

U.S. GEOLOGICAL SURVEY

Water-Resources Investigations Report 87-4259

Prepared in cooperation with the

SOUTHWEST FLORIDA WATER MANAGEMENT DISTRICT

Tallahassee, Florida 


\section{DEPARTMENT OF THE INTERIOR}

DONALD PAUL HODEL, Secretary

U.S. GEOLOGICAL SURVEY

Dallas L. Peck, Director

For additional information write to:

District Chief

U.S. Geological Survey Suite 3015

227 North Bronough Street Tallahassee, Florida 32301
Copies of this report can be purchased from:

U.S. Geological Survey Books and Open-File Reports Section Federal Center, Building 810

Box 25425

Denver, Colorado 80225 
Abstract

Introduction

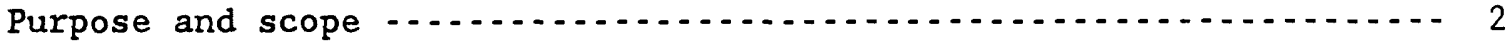

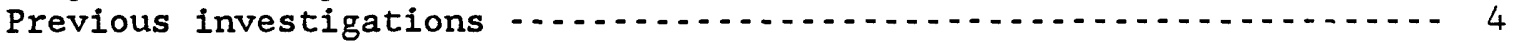

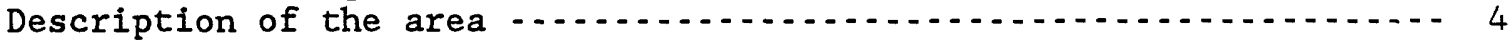

Geohydrologic framework and hydraulic properties

Potentiometric surface - . . .

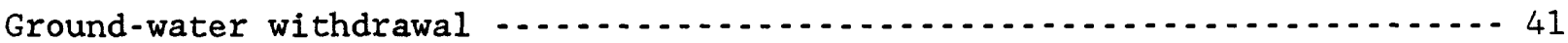

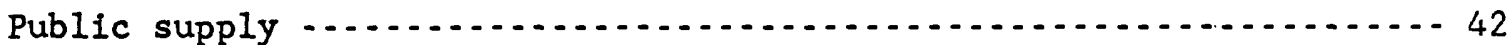

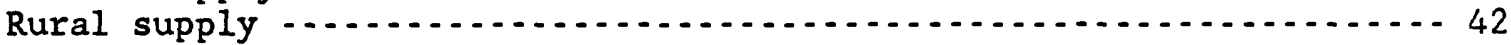

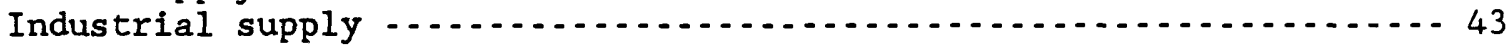

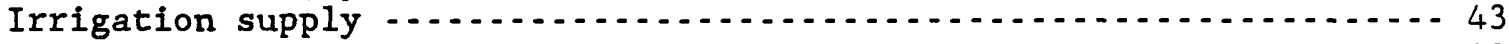

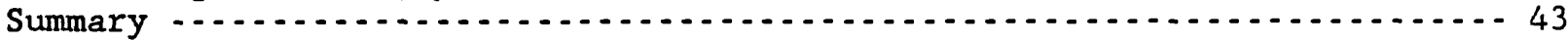

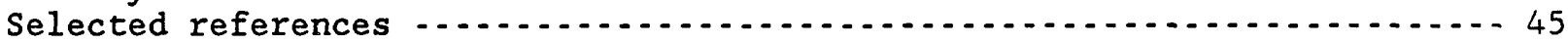

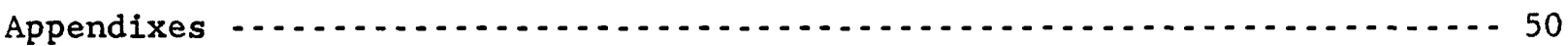

A. Records of monitor wells in the intermediate aquifer system in

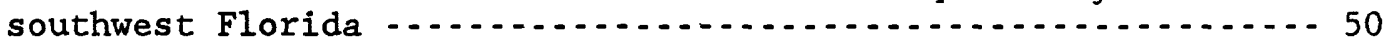

B. Index of geophysical logs in southwest florida $\ldots \ldots \ldots \ldots . \ldots . \ldots 6$

\section{ILLUSTRATIONS}

Figures 1-4. Maps showing:

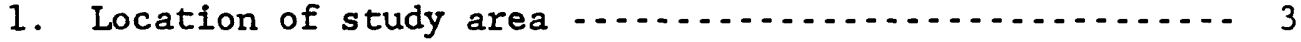

2. Topography of southwest Florida -............... 6

3. Locations of rivers and rainfall stations .......... 7

4. Locations of generalized geohydrologic sections -.... 10

5-10. Generalized geohydrologic sections:

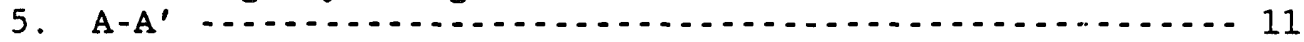

6. $\mathrm{B}-\mathrm{B}^{\prime}$

7. $C-C^{\prime} \ldots \ldots \ldots \ldots$

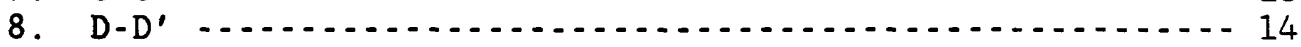

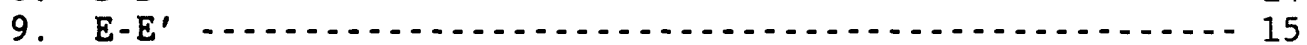

10. F-F'

11-22. Maps showing:

11. Altitude of the top of the intermediate aquifer

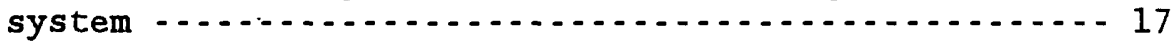

12. Thickness of the intermediate aquifer system ....... 18

13. Altitude of the bottom of the intermediate aquifer

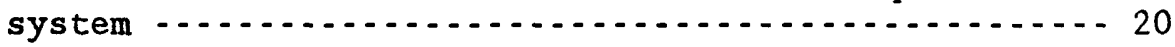

14. Locations of aquifer-test sites showing transmissivity determinations for the permeable parts of the intermediate aquifer system -...................... 21

15. Locations of wells in the intermediate aquifer system - 23

16. Potentiometric surface of the intermediate aquifer

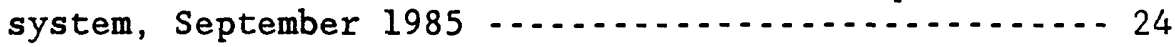

17. Potentiometric surface of the Upper Floridan aquifer,

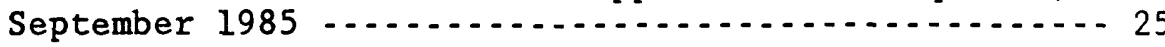


Figures 11-22. Maps showing--continued:

18. Head difference between the potentiometric surfaces of the intermediate aquifer system and the underlying Upper Floridan aquifer, September 1985 ..... 26

19. Potentiometric surface of the intermediate aquifer

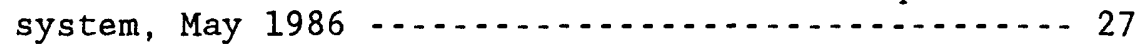

20. Potentiometric surface of the Upper Floridan aquifer May $1986 \ldots \ldots \ldots \ldots$

21. Head difference between the potentiometric surfaces of the intermediate aquifer system and the underlying Upper Floridan aquifer, May 1986 -......... 30

22. Locations of Regional Observation and Monitor Well

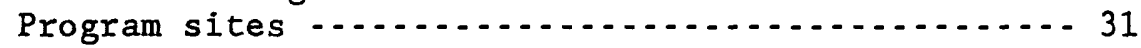

23-31. Graphs showing monthly rainfall at:

23. Bartow and daily maximum water levels at Regional Observation and Monitor Well Program site 57 .... 32

24. Bartow and daily maximum water levels at Regional Observation and Monitor Wel1 Program site 59 ..... 33

25. Bartow and daily maximum water levels at Regional Observation and Monitor We11 Program site $45 \ldots \ldots 34$

26. Bartow and daily maximum water levels at Regional Observation and Monitor We11 Program site $40 \ldots \ldots 35$

27. Ona and daily maximum water levels at Regional Observation and Monitor Well Program site $31 \ldots 36$

28. Arcadia and daily maximum water levels at Regional Observation and Monitor Well Program site $26 \ldots \ldots . . .37$

29. Venice and daily maximum water levels at Regional Observation and Monitor Well Program site TR5-1 ... 38

30. Venice and daily maximum water levels at Regional Observation and Monitor Well Program site TR5-2 -.. 39

31. Punta Gorda and daily maximum water levels' at Regional Observation and Monitor Well Program site TR3-1

TABLES

Table 1. Geohydrologic framework

2. Water withdrawn from the intermediate aquifer system, $1985 \ldots \ldots 2$ 


\title{
GEOHYDROLOGY AND 1985 WATER WITHDRAWALS OF THE AQUIFER SYSTEMS IN \\ SOUTHWEST FLORIDA, WITH EMPHASIS ON THE INTERMEDIATE AQUIFER SYSTEM
}

By A.D. Duerr, J.D. Hunn, B.R. Lewelling, and J.T. Trommer

\begin{abstract}
In a 4,700-square-mile area of southwest Florida, principal hydrogeologic units are the surficial aquifer system, the intermediate aquifer system, and the Floridan aquifer system. The thickness of the surficial aquifer system ranges from 25 to 250 feet, and transmissivity ranges from about 1,100 to about 8,000 feet squared per day.
\end{abstract}

The intermediate aquifer system includes all water-bearing units and confining units between the overlying surficial aquifer system and the underlying Floridan aquifer system. The top of the intermediate aquifer system ranges from more than 100 feet below sea level in Highlands County to more than 100 feet above sea level in central Polk County. Thickness ranges from less than 100 feet to more than 800 feet, and transmissivity ranges from less than 200 to about 13,000 feet squared per day. Leakance of the confining units ranges from $1 \times 10^{-7}$ to $4 \times 10^{4}$ foot per day per foot.

The Floridan aquifer system consists of the Upper and Lower Floridan aquifers separated by a "tight" middle confining unit. Transmissivity of the Upper Floridan aquifer in the study area ranges from about 30,000 feet squared per day at the gulf coast where the freshwater zone is thin to about 400,000 feet squared per day in eastern De Soto and Hardee Counties.

The altitude of the potentiometric surface of the intermediate aquifer system in September 1985 ranged from 120 feet above sea level in Polk County to less than 20 feet above sea level near the coast. In the northern part of the study area, water levels are higher in the intermediate aquifer system than water levels in the underlying Upper Floridan aquifer. The hydraulic gradient reverses in the southern part of the area.

In 1985, in the study area, an estimated 808 million gallons per day of freshwater was withdrawn from the surficial and intermediate aquifer systems and Upper Floridan aquifer for irrigation, public and rural supply, and industrial use. Of this total, an estimated 68.9 million gallons per day was withdrawn from the intermediate aquifer system. 
Southwest Florida has developed rapidly during the $1980^{\prime}$ s and in 1985 was one of the leading population growth areas in the State. Associated with this growth is an increasing demand for water for public supply, industrial, and agricultural uses.

In southwest Florida, ground water is the principal source of freshwater because of the lack of adequate surface-water storage. Three hydrogeologic units serve as a source of freshwater: the surficial aquifer system, the intermediate aquifer system, and the Floridan aquifer system. Because of low yield to wells and the potential for pollution, the surficial aquifer system has limited use, generally for lawn and garden irrigating and stock watering. The Upper Floridan aquifer of the Floridan aquifer system is the principal source of supply and yields large quantities of freshwater to wells in most areas. However, in the southern and coastal parts of the study area, the Upper Floridan aquifer contains water with a high mineral content. The intermediate aquifer system is an important source of water in Charlotte and Sarasota Counties; it also is used as a source of water throughout much of De Soto, Hardee, Highlands, Hillsborough, Manatee, and Polk Counties, although yields of individual wells and total withdrawal of water from the aquifer are generally much less than from wells open to the deeper Upper Floridan aquifer.

As the demand for water in southwest Florida increases, more information about the intermediate aquifer system is needed in order to more efficiently develop and manage this aquifer system as a water-supply source. Thus, in 1983, the U.S. Geological Survey, in cooperation with the Southwest Florida Water Management District, began a project to study the geohydrology of the intermediate aquifer system in southwest Florida.

\section{Purpose and Scope}

The purpose of this report is to present geohydrologic and water-use information on the intermediate aquifer system that will aid in the management of the aquifer system. Information on the surficial and Floridan aquifer systems is also presented but in less detail. The study area includes the southern half of the Southwest Florida Water Management District, an area of about 4,700 $\mathrm{mi}^{2}$, and includes all of De Soto, Hardee, Manatee, and Sarasota Counties and parts of Charlotte, Highlands, Hillsborough, and Polk Counties (fig. 1).

This report presents a description of the surficial, intermediate, and Floridan aquifer systems, defines the geohydrologic framework, and presents water-withdrawal data, potentiometric-surface maps, a table showing records of wells, and an index of geophysical logs. The depth, thickness, and extent of the intermediate aquifer system was determined from geologic and geophysical logs of wells from the files of the U.S. Geological Survey, the Florida Bureau of Geology, and the Southwest Florida Water Management District. A network of water-level observation wells was established and measured to determine the potentiometric surface of the intermediate aquifer system for September 1985 and May 1986. 


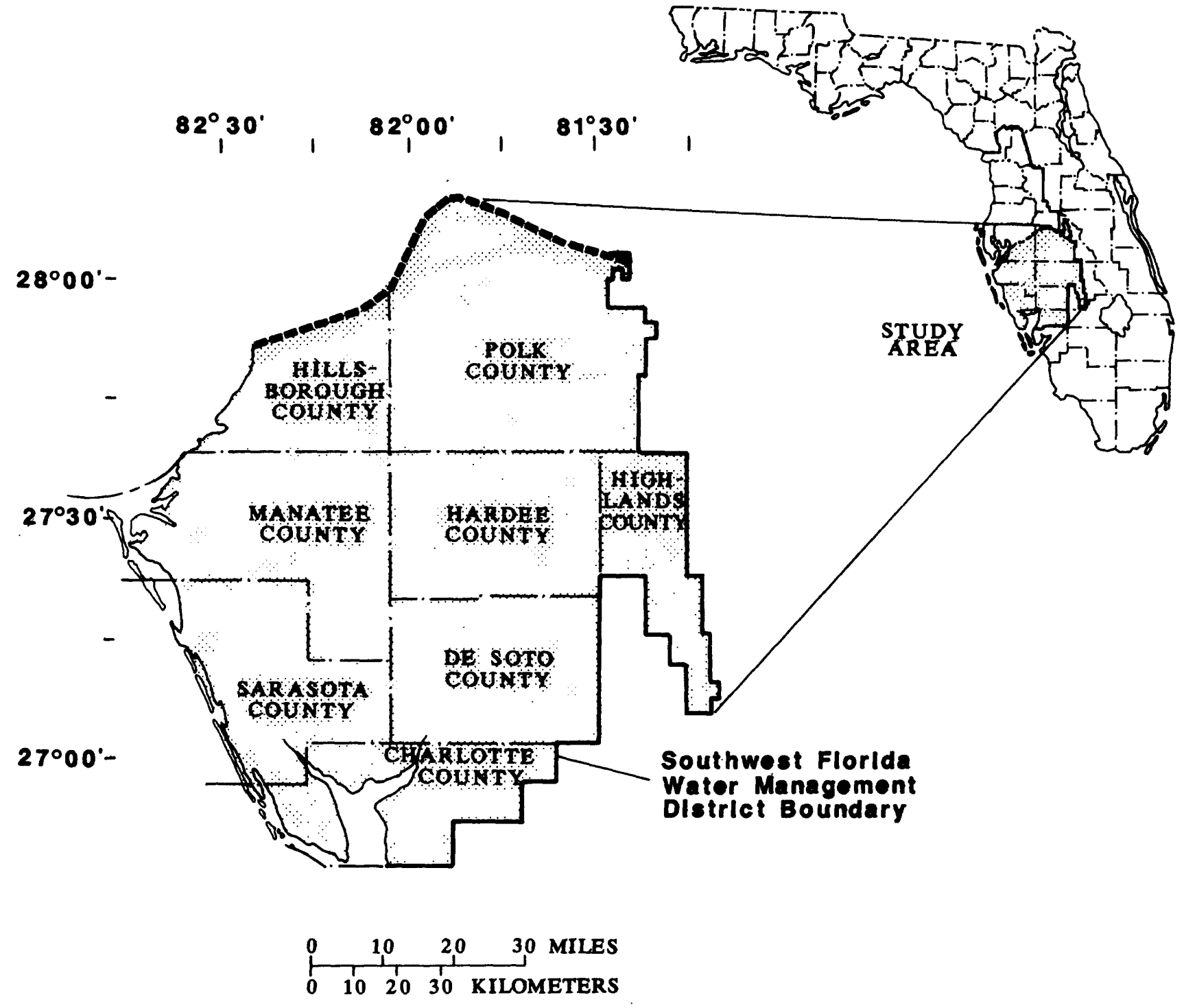

Figure 1.--Location of study area. 
Numerous reports have been written about the geology and hydrology of southwest Florida, but few reports focus specifically on the intermediate aquifer system. Most of the published information about the aquifer system is limited to public well fields and phosphate plant sites where test drilling has been completed and aquifer tests conducted.

Several previous reports provide geologic and ground-water information. Stringfield (1933a; 1933b) described the geology and ground-water conditions in Sarasota County. Heath and Smith (1954) described the ground-water resources in Pinellas County. The stratigraphy of shallow deposits in De Soto and Hardee Counties was reported by Bergendahl (1956). Bishop (1956) identified marine and nonmarine deposits of the Hawthorn Formation in Highlands County. Peek (1958; 1959a; 1959b) described the geology and ground-water resources in Manatee and southwest Hillsborough Counties. The water resources of Hillsborough County also were described by Menke and others (1961). Eppert (1966) reported on the stratigraphy of the upper Miocene deposits in Sarasota County, and Stewart (1966) described the ground-water resources of Polk County. Kaufman and Dion (1968) presented data on the ground-water resources of Charlotte, De Soto, and Hardee Counties. The water resources of Charlotte County were further described by Sutcliffe (1975). Joyner and Sutcliffe (1976) reported on the water resources of the Myakka River basin area. Wilson (1977) provided information on the ground-water resources of De Soto and Hardee Counties that included the geology and hydrology of the intermediate aquifer. Hutchinson (1978) gave an appraisal of the shallow ground-water resources in the upper Peace and eastern Alafia River basins.

Buono and others (1979) presented the generalized thickness of the confining unit overlying the Upper Floridan aquifer throughout southwest Florida. Franks (1982) presented summary information on the principal aquifers in Florida. Brown (1983) described the upper confining unit and presented waterlevel data for the intermediate aquifer system in Manatee County. Wolansky (1983) subdivided the intermediate aquifer into several units in the SarasotaPort Charlotte area. A description of the intermediate aquifer was included by Miller (1986) in his regional description of the Floridan aquifer system. Corral and Wolansky (1984) mapped the configuration of the top of the intermediate aquifer system in southwest Florida but did not include the confining layer below the surficial aquifer system as part of the intermediate aquifer system. The geology of the intermediate aquifer system was included in a report by Ryder (1985) describing the hydrology of the Floridan aquifer system in west-central Florida. A report by Duerr and Wolansky (1986) described the hydrogeology of the surficial and intermediate aquifer systems of central Sarasota County, Florida.

Description of the Area

The area is highly urbanized near the coast and rural in the interior. Major industries include agriculture, phosphate mining, chemical processing, food processing, and tourism. Agricultural land use includes citrus groves, vegetable farms, nurseries, and rangeland. 
Topography is characterized by a low-lying coastal plain that gradually rises toward the east and is bordered by sand-covered ridges more than 150 feet above sea level (fig. 2). There are numerous lakes in the ridge areas. Surface-water drainage is relatively well developed with streams draining south and west into the Gulf of Mexico.

The climate of southwest Florida is characterized by warm, humid summers and mild, moderately dry winters. The Gulf of Mexico moderates the extremes in temperature so that winter low temperatures are several degrees higher along the coast than in inland areas. The average July temperature at Wauchula (fig. 3) is $81.5^{\circ} \mathrm{F}$ and the average January temperature is $61.5^{\circ} \mathrm{F}$. Rainfall varies seasonally with more than half the annual total occurring from June to September. Average rainfall from five weather stations (A through E, fig. 3) for the period 1915 to 1976 was 53.1 in/yr (Palmer and Bone, 1977, p. 6).

\section{GEOHYDROLOGIC FRAMEWORK AND HYDRAULIC PROPERTIES}

The geohydrologic system in the study area consists of thick sequences of carbonate rock overlain by clastic deposits. Principal hydrogeologic units are the surficial aquifer system, the intermediate aquifer system, and the Floridan aquifer system (Southeastern Geological Society, 1986). The hydrogeologic units, the corresponding time-stratigraphic units, and general lithology are given in table 1 .

The surficial aquifer system overlies the intermediate aquifer system and consists of Holocene and Pleistocene deposits containing sand, clayey sand, she11, shelly marl, and some phosphorite. The thickness of the deposits was mapped by Wolansky, Spechler, and Buono (1979). Thickness ranges from about 25 feet near the coast and low-lying areas to about 250 feet in Highlands County. The surficial aquifer system is a major source of recharge to the intermediate aquifer system. The surficial aquifer system is unconfined and is not a major source of water except in the southern part of the study area where deeper limestone aquifers are highly mineralized.

The hydraulic properties of the surficial aquifer system vary with saturated thickness and lithology. Wolansky (1983, p. 16) reported hydraulic properties from six aquifer tests in Sarasota and southwestern De Soto Counties; transmissivity ranges from 600 to $8,000 \mathrm{ft}^{2} / \mathrm{d}$, and storage coefficient determined from two tests ranges from 0.05 to 0.16 . R.M. Wolansky (U.S. Geological Survey, written commun., 1980) reported a transmissivity of 1,800 $\mathrm{ft}^{2} / \mathrm{d}$ for a site in southeast Hillsborough County. For two sites in southern Polk County, Hutchinson (1978, p. 20) reported transmissivities of 1,600 and $2,200 \mathrm{ft}^{2} / \mathrm{d}$ and storage coefficients of 0.05 and 0.005 . Wilson (1977, p. 28) estimated an average transmissivity of about $1,100 \mathrm{ft}^{2} / \mathrm{d}$ for the surficial aquifer system in Hardee and De Soto Counties.

The intermediate aquifer system includes all water-bearing units (aquifers) and confining units between the overlying surficial aquifer system and the underlying Floridan aquifer system. The water-bearing units of the intermediate aquifer system consist of discontinuous sand, gravel, she11, and limestone and dolomite beds in the Tamiami Formation of early Pliocene age and the Hawthorn Formation of late and middle Miocene age. The intermediate 


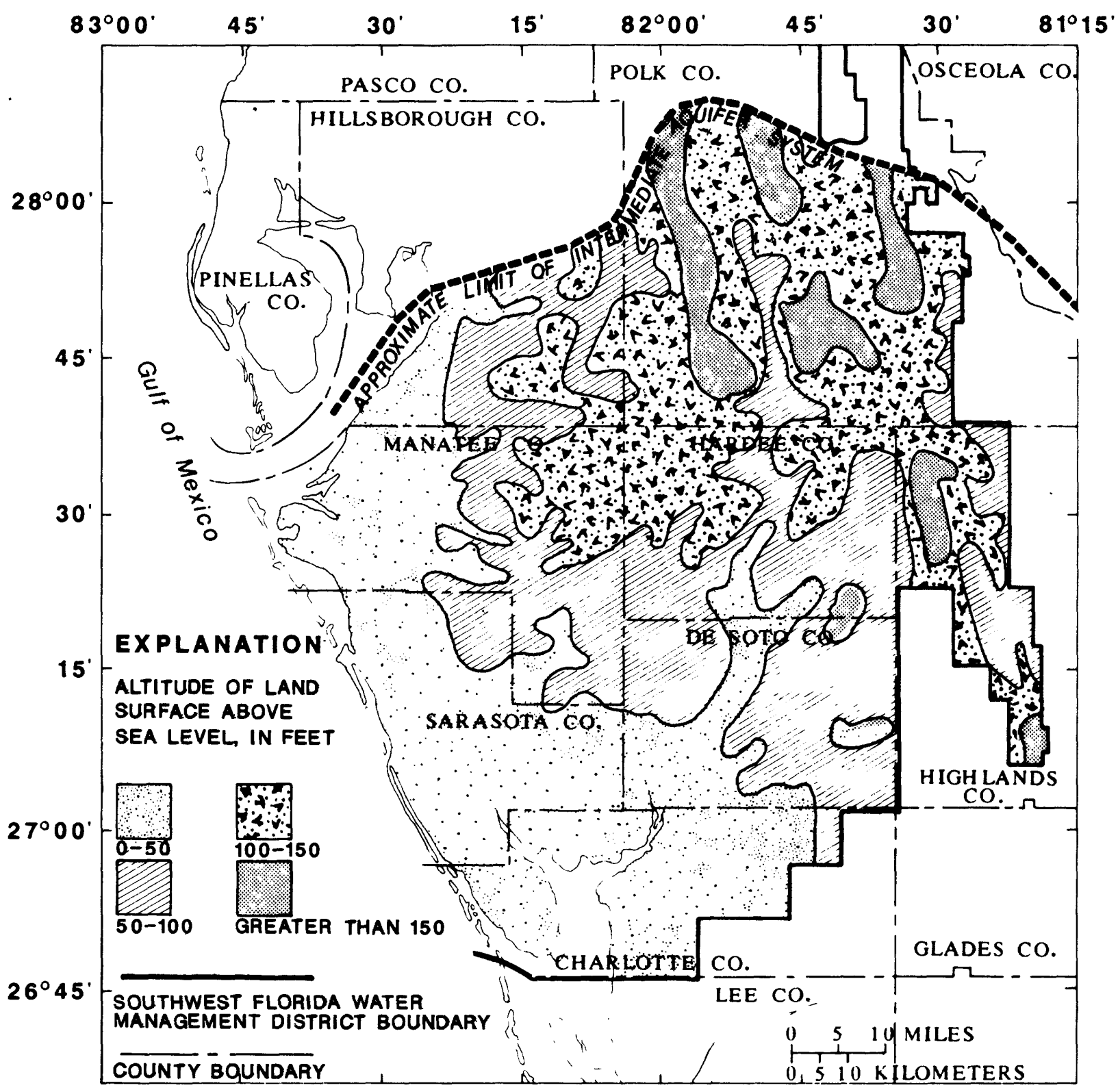

Figure 2.--Topography of southwest Florida.

(From Sinclair and others, 1985.) 


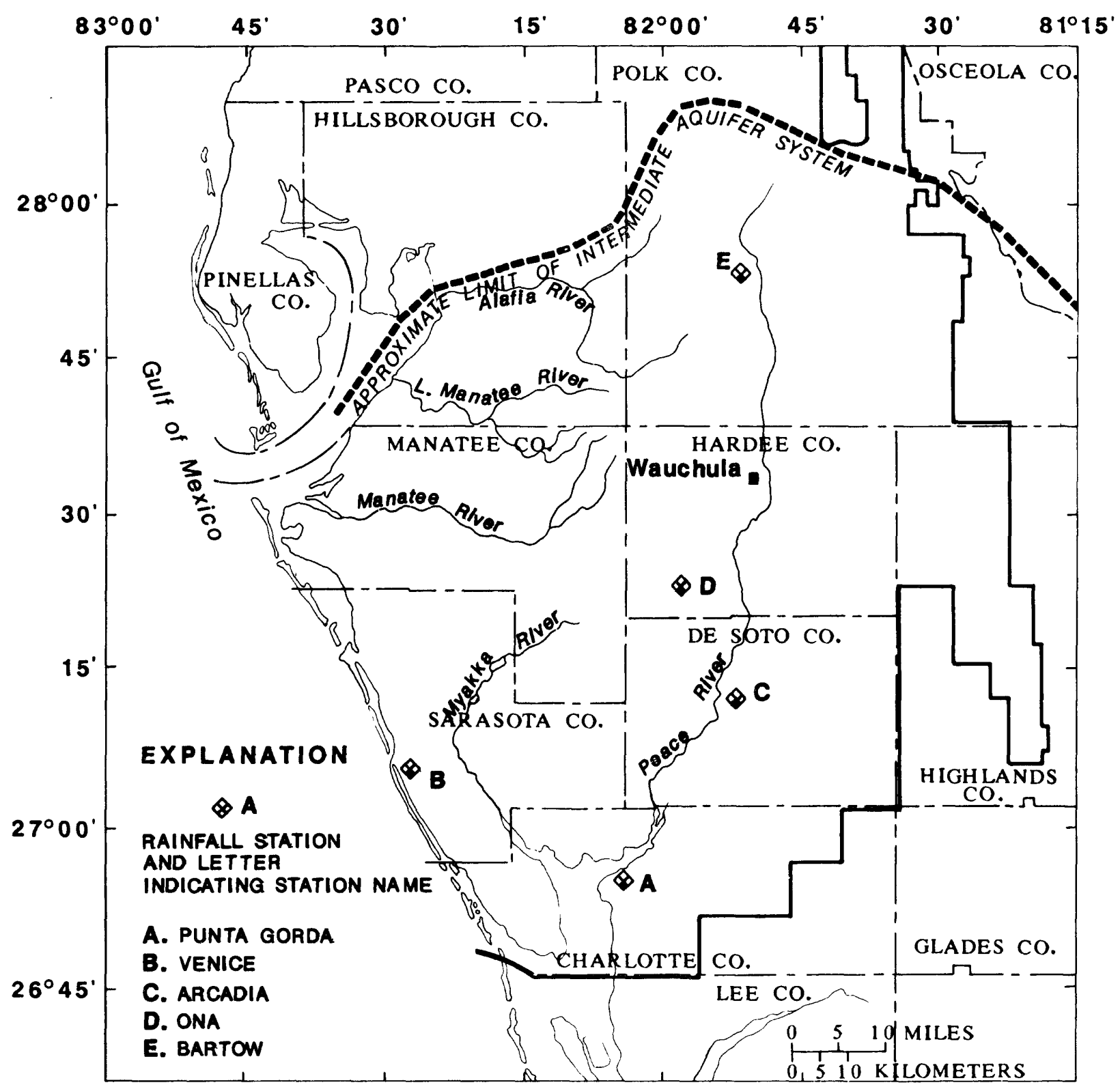

Figure 3.--Locations of rivers and rainfall stations. 


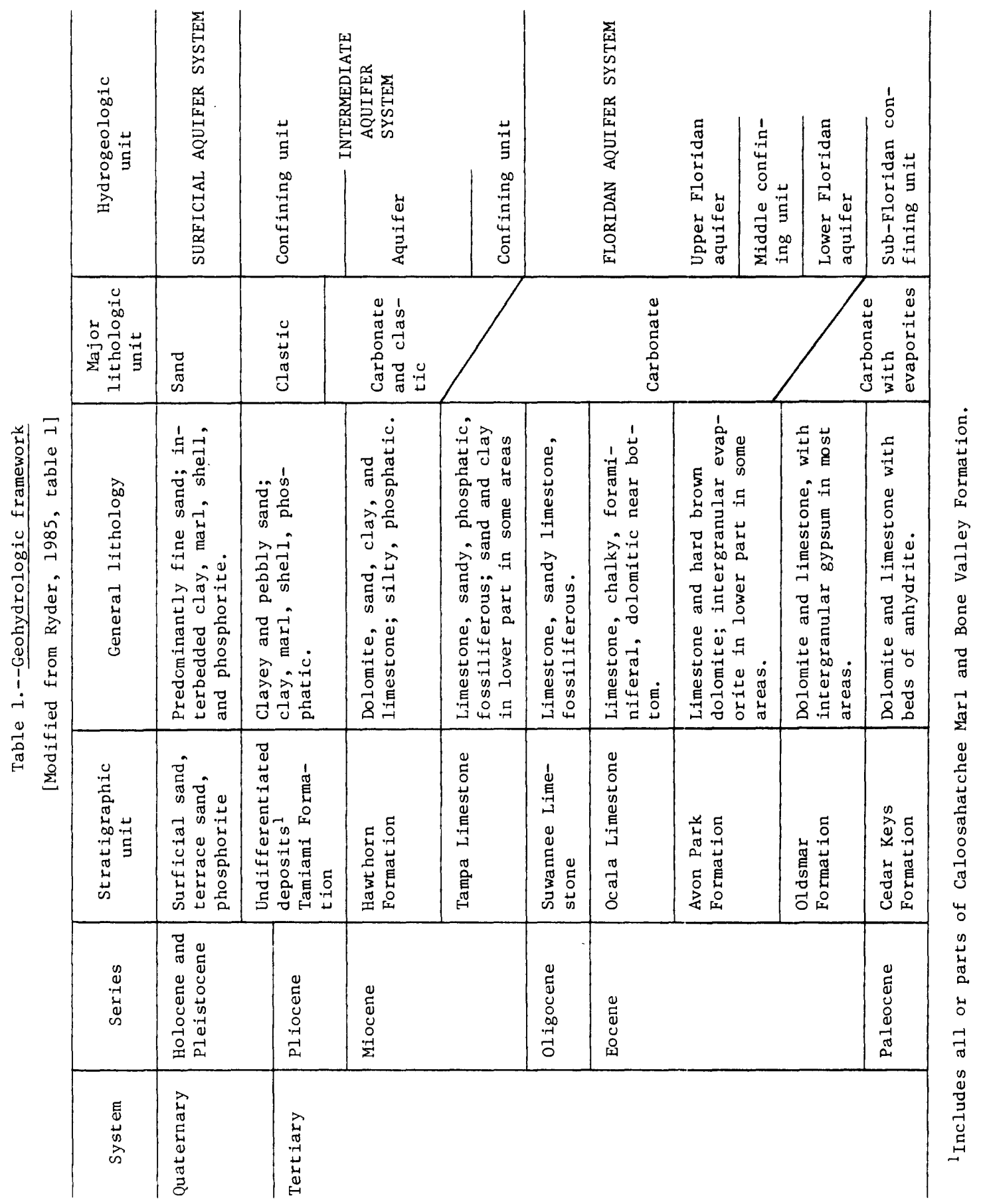


aquifer system contains confining units that consist of sandy clay, clay, and marl. These confining units retard vertical movement of ground water between the water-bearing units and the overlying surficial aquifer system and the underlying Upper Floridan aquifer.

In parts of Polk, Manatee, Hardee, De Soto, Sarasota, and Charlotte Counties, sand and clay beds within the Tampa Limestone are hydraulically connected to the Hawthorn Formation and are also included in the intermediate aquifer system (Corral and Wolansky, 1984). In these areas, a confining unit separates the Tampa Limestone from the underlying Floridan aquifer system.

Within the intermediate aquifer system are deposits of sufficient permeability to be used as important water supplies in coastal areas. In coastal. Charlotte and Sarasota Counties, the intermediate aquifer system contains some slightly saline water that is treated by reverse osmosis before it is used for public supply (Sutcliffe and Thompson, 1983). In other parts of the study area, water from the intermediate aquifer system receives only minimal treatment before being distributed for use.

The intermediate aquifer system thus consists of three hydrogeologic units (table 1): (1) a sandy clay and clayey sand confining unit in the lower part that lies directly on top of the Floridan aquifer system; (2) an aquifer system that consists of one, two, or three water-bearing units (aquifers) composed primarily of sand and carbonate rocks; and (3) a sandy clay, clay, and marl confining unit in the upper part that separates the aquifers in the intermediate aquifer system from the overlying surficial aquifer system (Ryder, 1985).

The water-bearing units (aquifers) of the intermediate aquifer system are equivalent to the secondary artesian aquifer as used by stewart (1966) for Polk County; to zones 2 and 3 as used by Sutcliffe (1975) for Charlotte County; to the upper and lower Hawthorn aquifers as used by Sproul and others (1972) for part of Lee County; and to the upper unit of the Floridan aquifer as used by Wilson (1977) for De Soto and Hardee Counties.

The locations of six generalized geohydrologic sections are shown in figure 4. The sections, shown in figures 5 through 10 , were constructed primarily from geologists' logs of test wells. Geophysical logs also were used for correlating aquifers. The sections show the relative positions of the surficial, intermediate, and Floridan aquifer systems. The sections also show the confining units and water-bearing units (aquifers) at specific test holes within the intermediate aquifer system. There are lateral inconsistencies between interpretations of rock stratigraphic units in the study area and they are not included in the sections.

In southwest Florida, the top of the intermediate aquifer system ranges from more than 100 feet below sea level in Highlands County to more than 100 feet above sea level in central Polk County (fig. 11). Throughout most of the southern and western parts of the study area, the top of the intermediate aquifer system is within 50 feet of sea level. Along the gulf coast, it lies about 20 feet below sea level. The thickness of the intermediate aquifer system ranges from less than 100 feet in central Hillsborough and northern Polk Counties to more than 800 feet in southern Charlotte County (figs . 6, 7, and 12). The intermediate aquifer system is intermittent near its northern extent and its boundary is approximated by a dashed line in figure 12 . The bottom of the intermediate aquifer system (top of the Floridan aquifer system) 


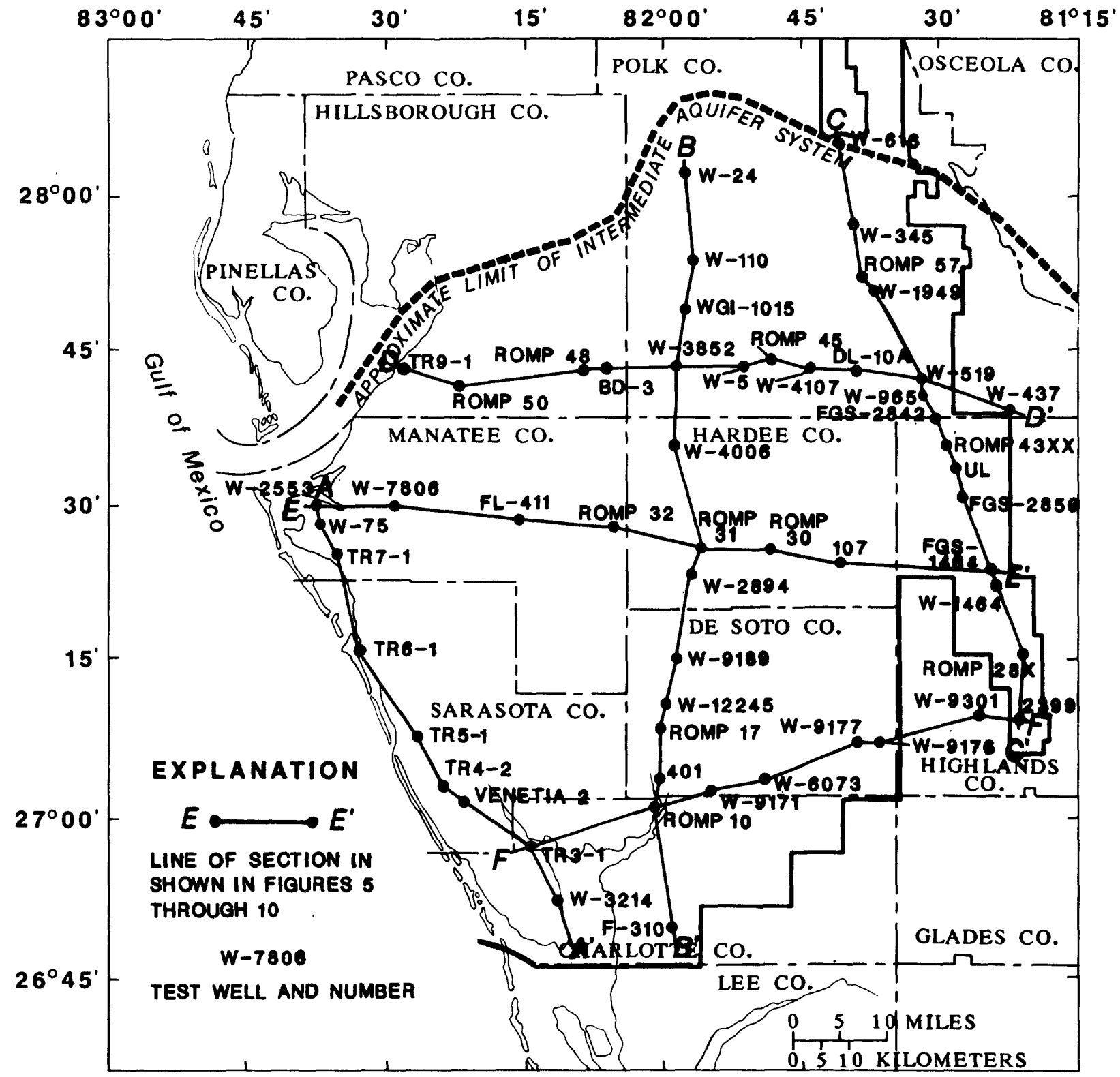

Figure 4.--Locations of generalized geohydrologic sections. 


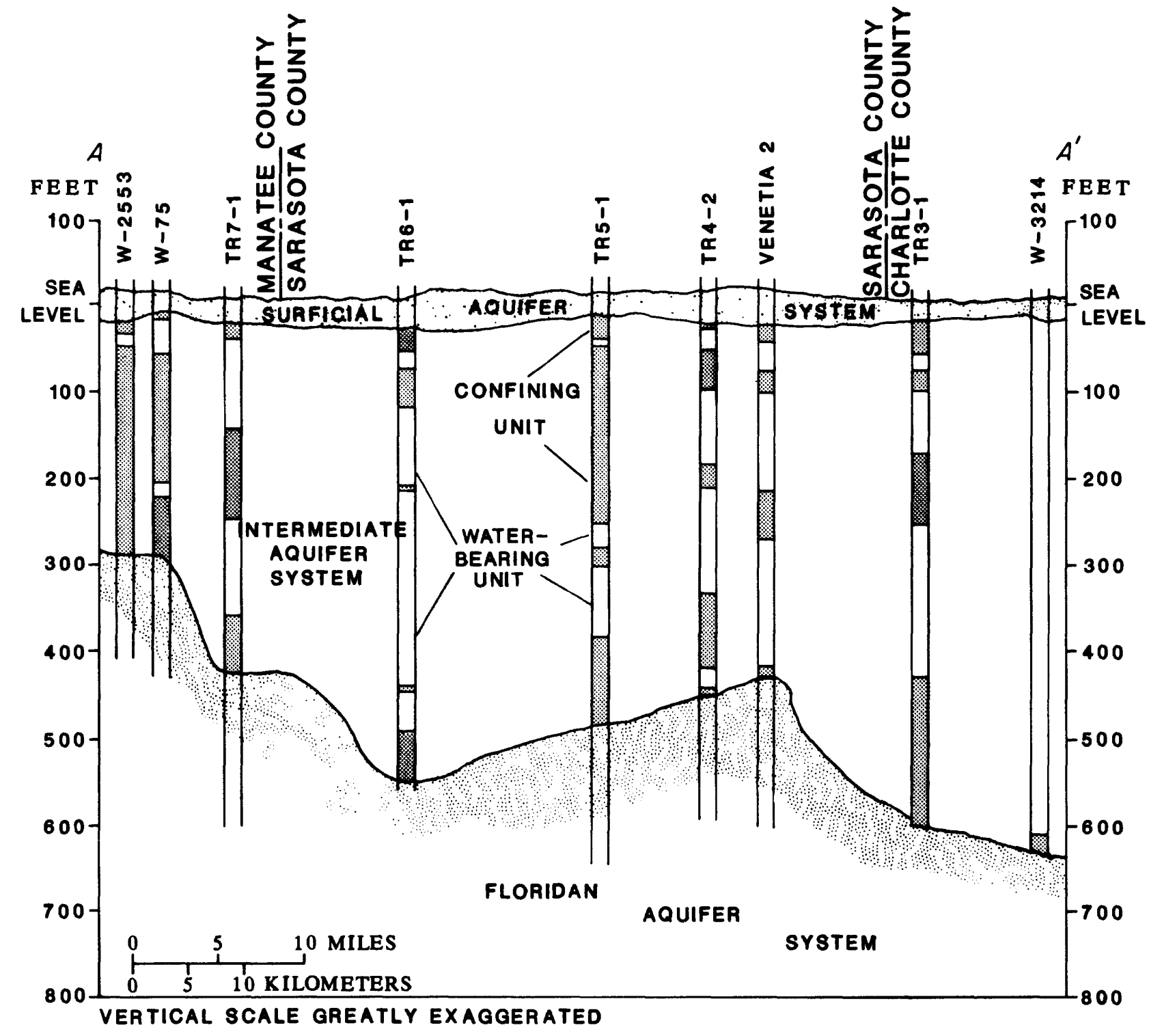

Figure 5.--Generalized geohydrologic section A-A'. 


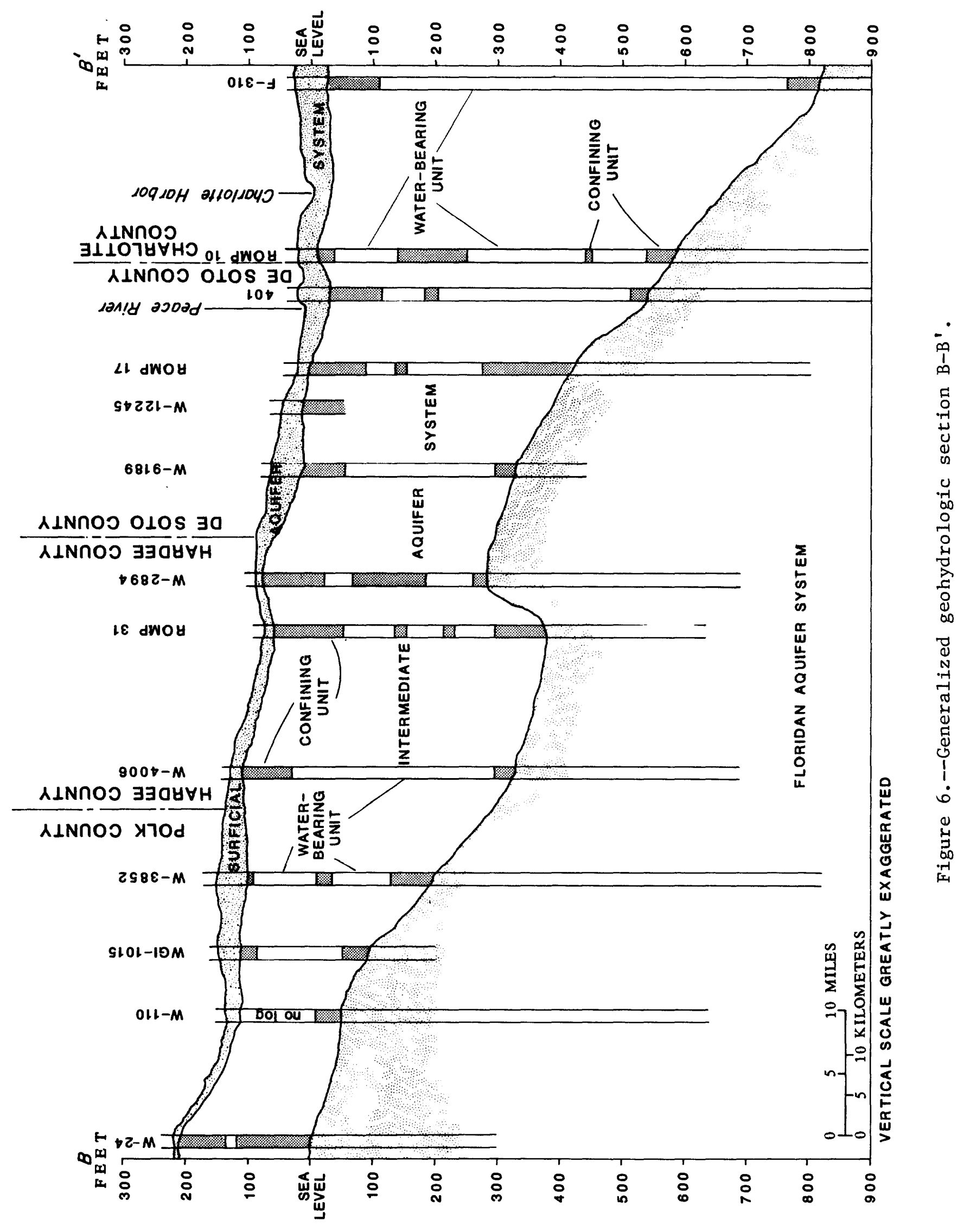




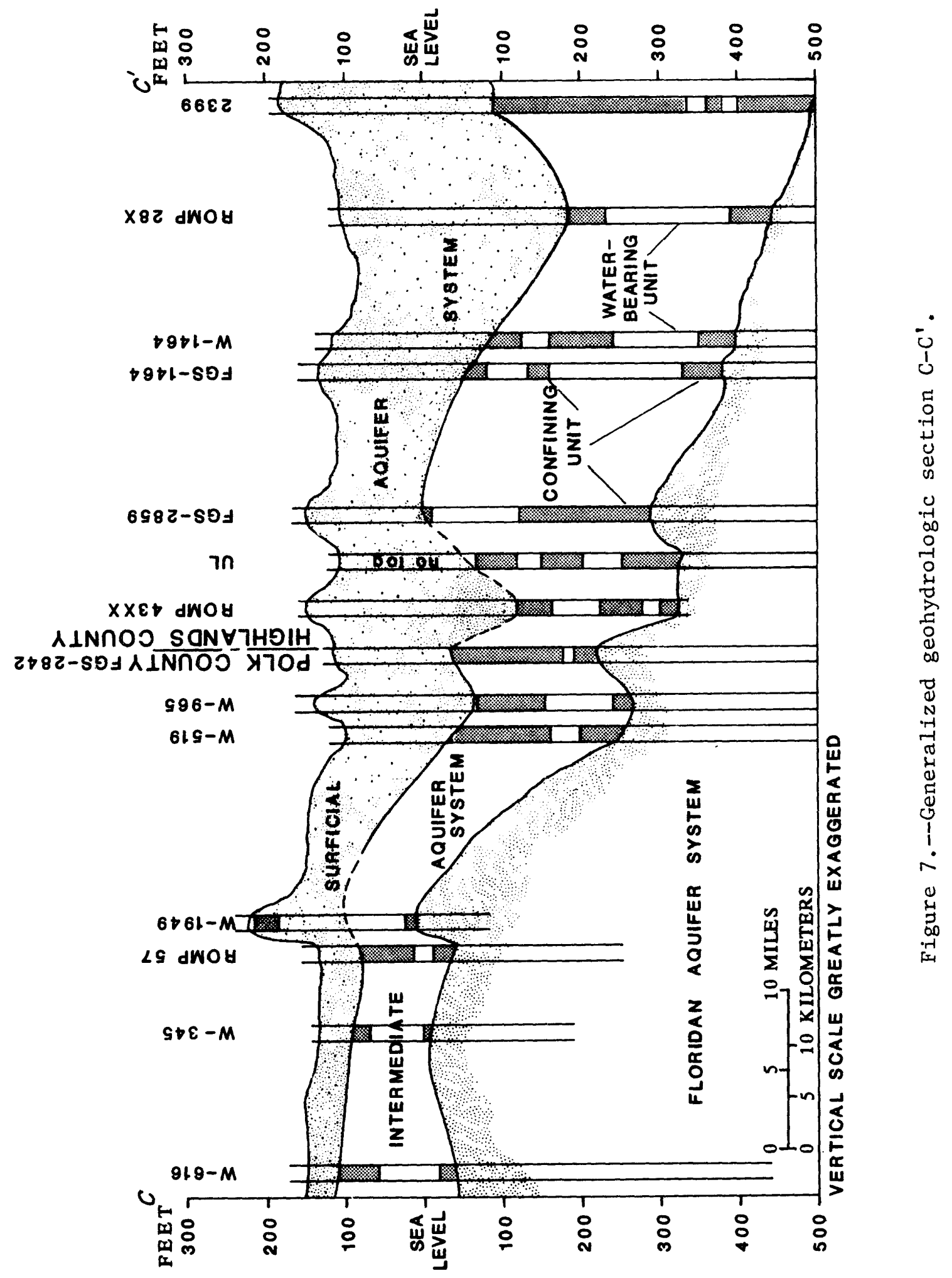




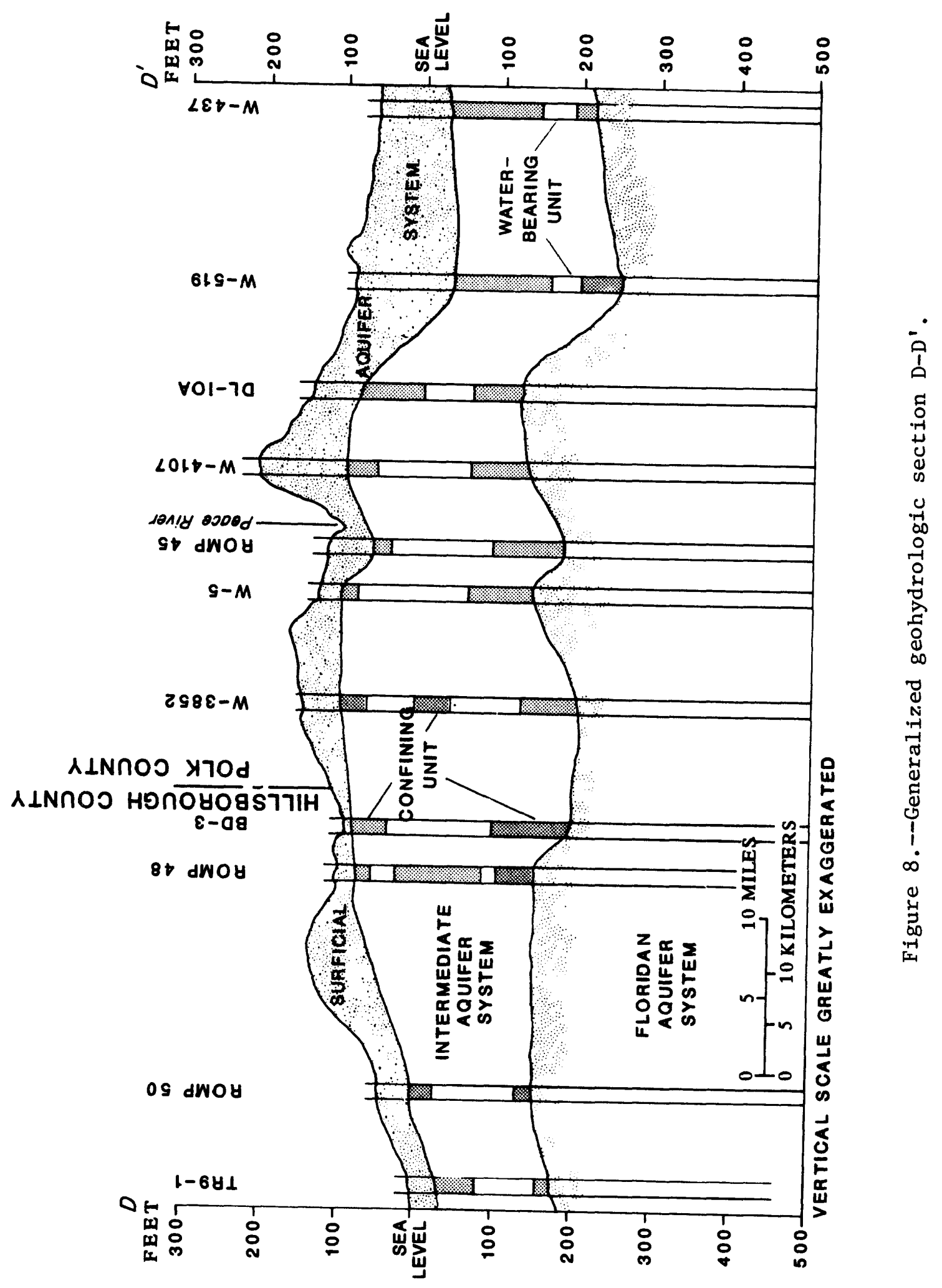




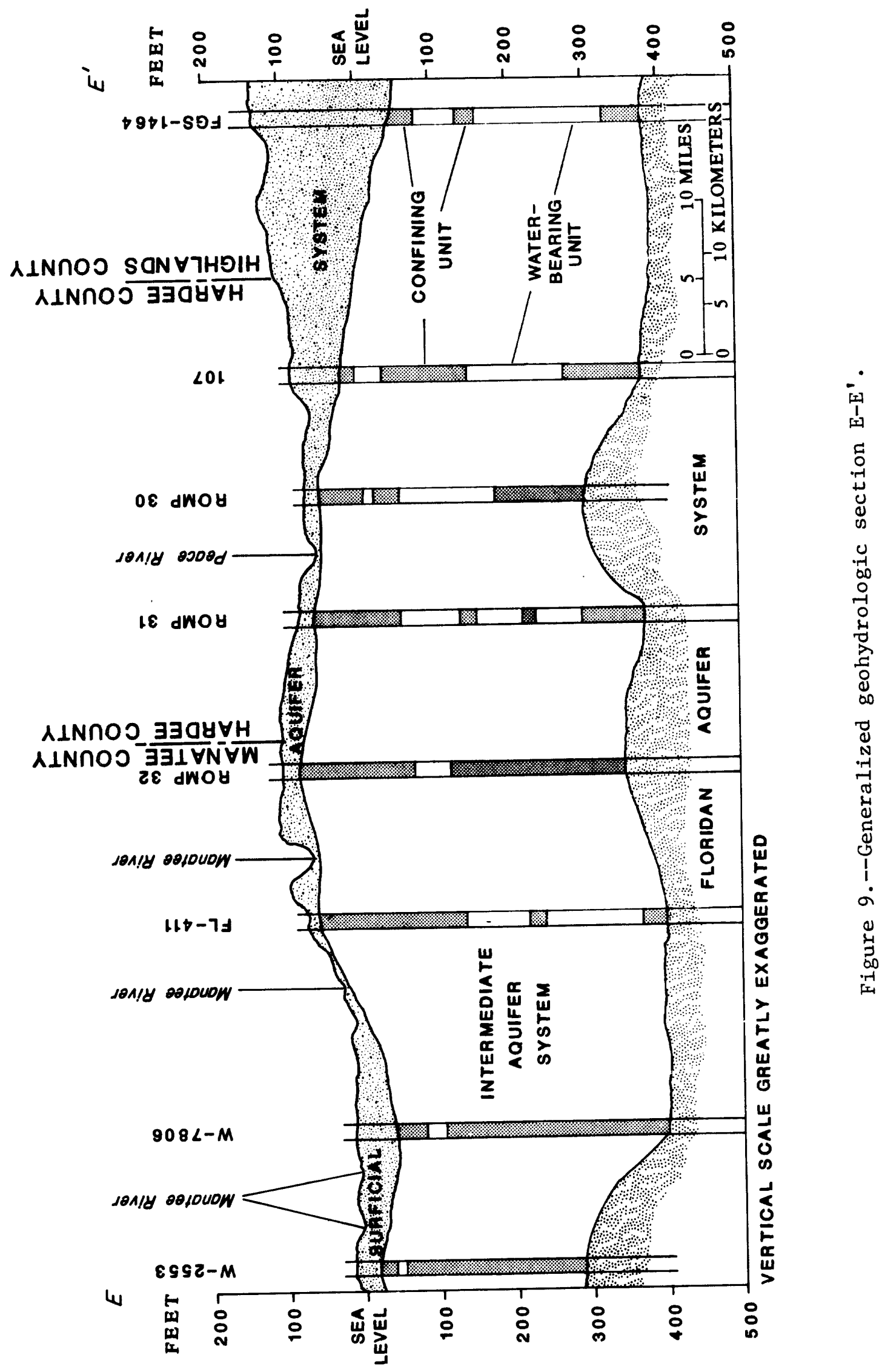




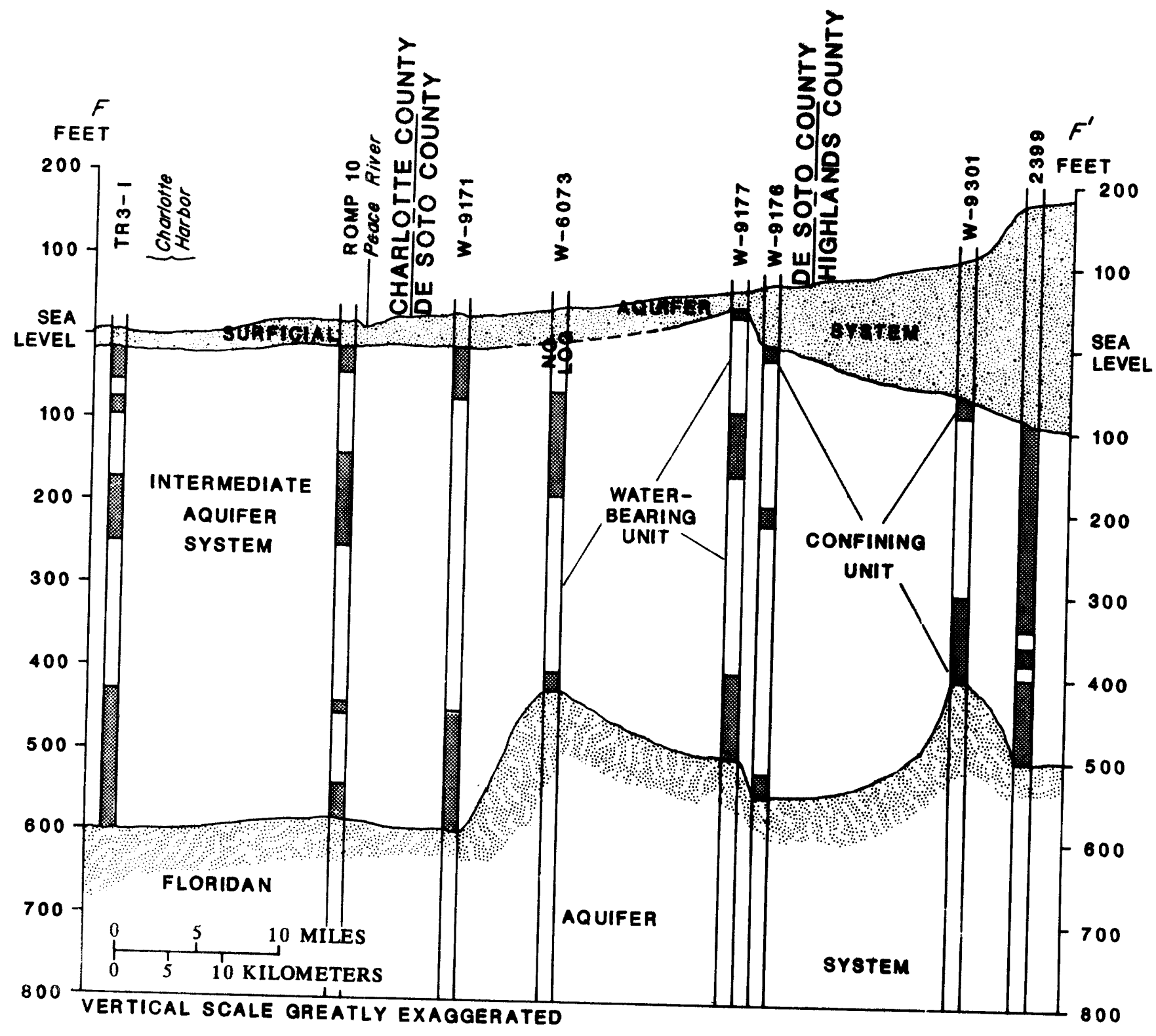

Figure 10.--Generalized geohydrologic section F-F'. 


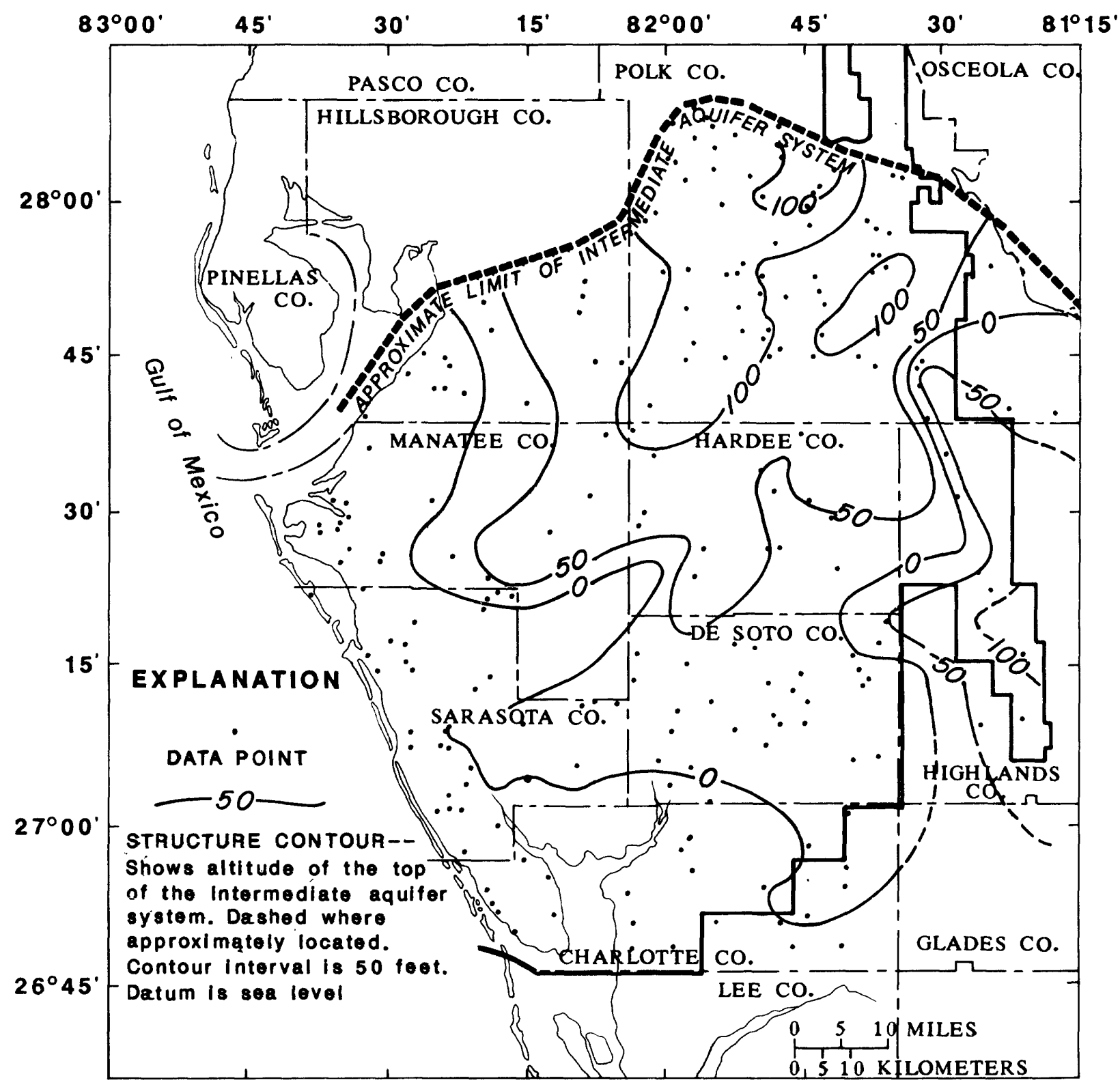

Figure 11.--Altitude of the top of the intermediate aquifer system. 


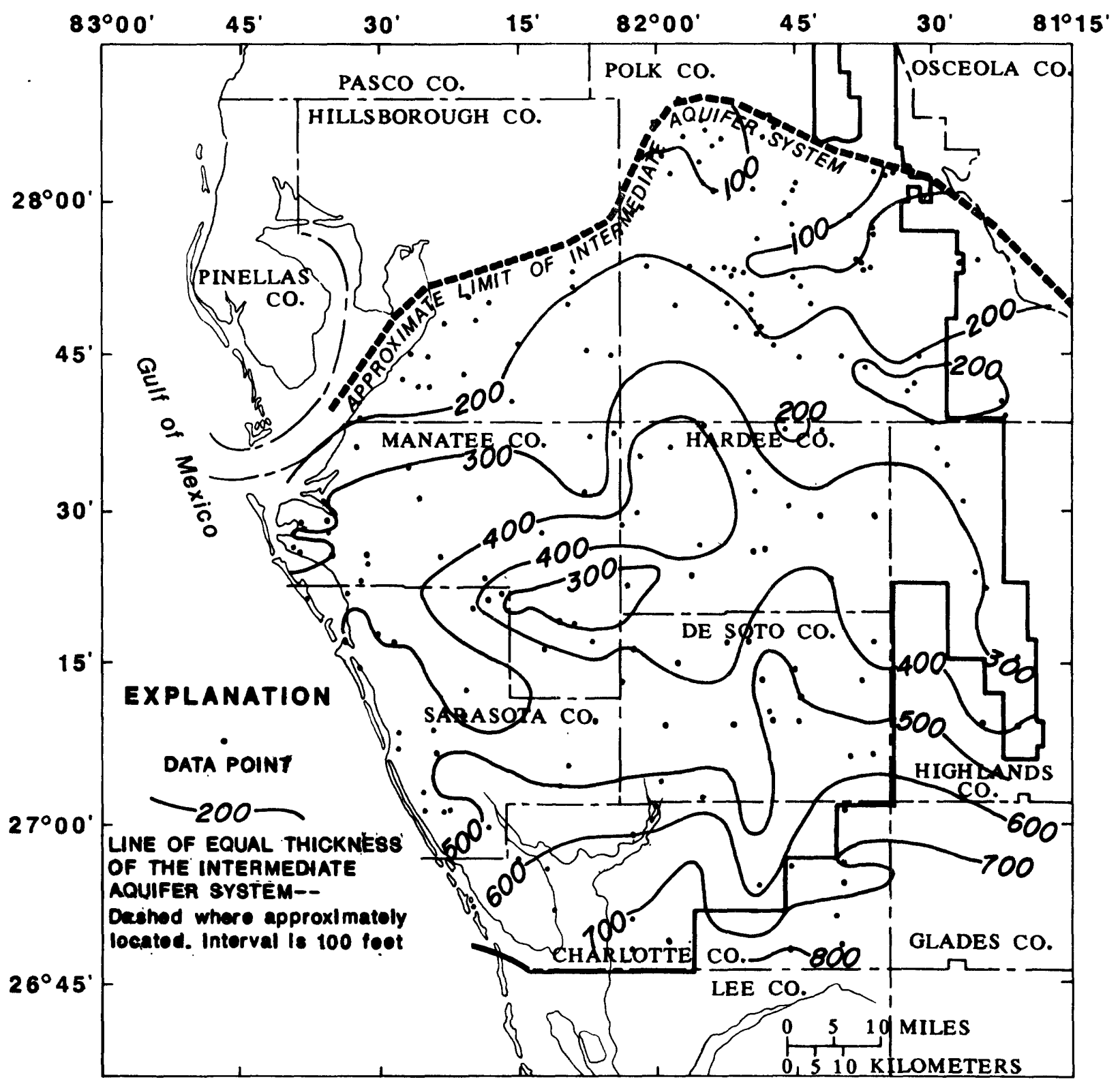

Figure 12.--Thickness of the intermediate aquifer system. 
ranges from about 50 feet above sea level in northern Polk county to more than 800 feet below sea level in southern Charlotte County (fig. 13).

Transmissivities of the water-bearing units of the intermediate aquifer system, as determined by field tests, are shown in figure 14 (Ryder, 1982). Transmissivity ranges from less than 200 to about $13,000 \mathrm{ft}^{2} / \mathrm{d}$. Transmissivity is generally less than $1,000 \mathrm{ft}^{2} / \mathrm{d}$ in eastern Hillsborough and northern Polk Counties where the permeable deposits are thin. Near the Peace River, transmissivity is generally higher than 4,000 $\mathrm{ft}^{2} / \mathrm{d}$, indicating that perhaps a more active flow system exists in a carbonate section where ground water discharges to the river and the carbonate rocks' secondary porosity has been enhanced by dissolution, thus providing greater permeability (Ryder, 1982, p. 23).

Clay beds of limited lateral extent and variable thickness may occur within the water-bearing units of the intermediate aquifer system, particularly near the coast. Where laterally persistent clay beds occur, the waterbearing units have been separated into two or three local artesian zones by some investigators (Joyner and Sutcliffe, 1976; Sutcliffe and Thompson, 1983; Wolansky, 1983).

The water-bearing units of the intermediate aquifer system are confined above and below by less permeable material. Leakance of the uppermost confining unit used by Ryder (1985) in a ground-water flow model of westcentral Florida ranges from $7 \times 10^{-6}(\mathrm{ft} / \mathrm{d}) / \mathrm{ft}$ in western Manatee County to $4 \times 10^{-4}(\mathrm{ft} / \mathrm{d}) / \mathrm{ft}$ near the Tampa Bay coast in southwest Hillsborough County. Leakance of the lowermost confining unit of the intermediate aquifer system ranges from $1 \times 10^{-7}$ ( $\mathrm{ft} / \mathrm{d}$ )/ft in southwest Sarasota and western Charlotte Counties to $7 \times 10^{-5}$ ( $\mathrm{ft} / \mathrm{d}$ )/ft in the eastern part of the study area (Ryder, 1985). The confining units have low hydraulic conductivity and consequently retard interaquifer ground-water flow and yield little water to wells. However, these confining units do transmit, or leak, water from one aquifer to another, and the system is referred to as a leaky-aquifer system (Wilson, 1977, p. 37).

The underlying Floridan aquifer system is defined as a vertically continuous sequence of carbonate rocks of generally high permeability that are of Tertiary age, that are hydraulically connected to each other in varying degrees, and whose permeability is several orders of magnitude greater than that of the rocks that bound the system above and below (Ryder, 1985).

The Floridan aquifer system (Miller, 1986) consists of the Upper and Lower Floridan aquifers separated by a "tight" middle confining unit. The middle unit and Lower Floridan aquifer generally contain saltwater (Ryder, 1985). In most reports on the hydrology of southwest Florida, the term "Floridan aquifer" has been applied to the water-bearing rocks herein referred to as the Upper Floridan aquifer. It is the major source of fresh ground water for most of southwest Florida. Transmissivity of the Upper Floridan aquifer in the study area ranges from about $30,000 \mathrm{ft}^{2} / \mathrm{d}$ at the gulf coast where the freshwater zone is thin to about $400,000 \mathrm{ft}^{2} / \mathrm{d}$ in eastern De Soto and Hardee Counties (Ryder, 1985). 


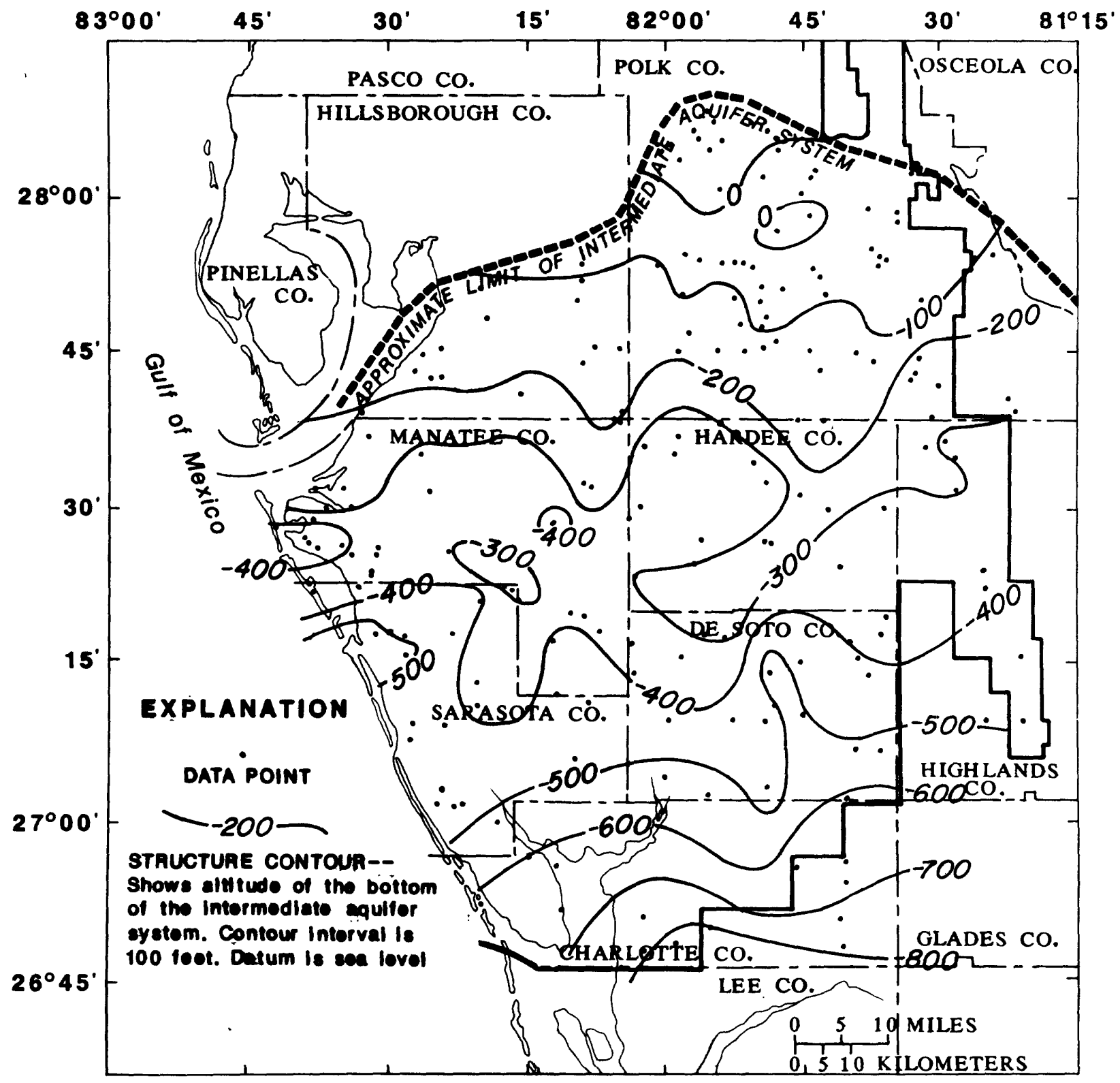

Figure 13.--Altitude of the bottom of the intermediate aquifer system. 


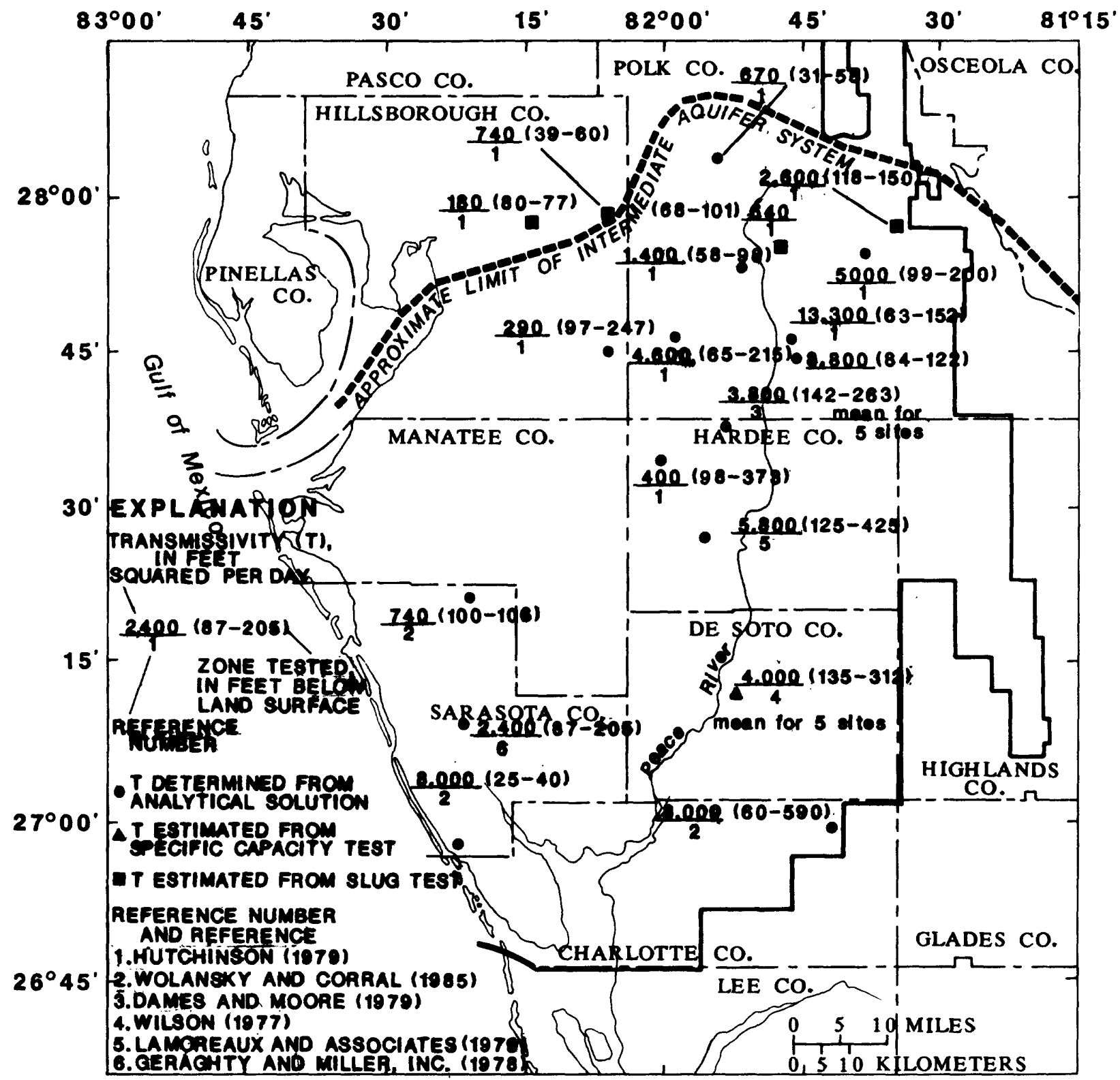

Figure 14.--Locations of aquifer-test sites showing transmissivity determinations for the permeable parts of the intermediate aquifer system. 


\section{POTENTIOMETRIC SURFACE}

The potentiometric surface, or hydraulic head, is an imaginary surface connecting points to which water would rise in tightly cased wells from a given point in an aquifer (Lohman, 1972). Potentiometric-surface maps of the intermediate aquifer system were constructed from water-level measurements made in 115 wells (fig. 15). Construction data and measurements for September 1985 and May 1986 are shown in appendix A. We1ls were measured at the end of the normally wet season (September) and at the end of the normally dry season (May). In areas where multiple aquifers exist in the intermediate aquifer system, wells open to all aquifers in the system were selected for water-level measurements whenever possible. Thus, the potentiometric-surface maps of the intermediate aquifer system represent an average pressure surface.

The potentiometric surface of the intermediate aquifer system in September 1985 is shown in figure 16. The altitude of the potentiometric surface ranges from about 120 feet above sea level in Polk County to less than 20 feet above sea level near the coast. Lateral flow from areas of high potential to areas of low potential is generally south and west toward the coast.

The potentiometric surface of the underlying Upper Floridan aquifer in September 1985 was mapped by Barr (1985) and is shown in figure 17 . Head differences between the intermediate aquifer system and the Upper Floridan aquifer in September 1985 are shown in figure 18. In the northern part of the study area, heads in the intermediate aquifer system are higher than heads in the underlying Upper Floridan aquifer. Water is transmitted downward through the confining unit and recharges the Upper Floridan aquifer. The gradient in head reverses in the southern part of the study area where the underlying Upper Floridan aquifer has a higher head than the head in the intermediate aquifer system. There, water is transmitted upward through the confining unit and recharges the intermediate aquifer system. Head differences between the intermediate aquifer system and the Upper Floridan aquifer range from more than +60 feet near the corner of Hillsborough, Manatee, Polk, and Hardee Counties to about -15 feet in western Sarasota County.

The potentiometric surface of the intermediate aquifer system is generally higher than the water level in the surficial aquifer system in the lowlying areas near the Peace River. As a result, in these areas, ground water moves upward from the intermediate aquifer system into the surficial aquifer system. The upward flow tends to depress the potentiometric surface of the intermediate aquifer system near the Peace River (fig. 16). Along reaches of the river where the Hawthorn Formation crops out, as in parts of Hardee and northern De Soto Counties, ground water may discharge by spring flow directly from the intermediate aquifer system to the river.

Figure 19 shows the potentiometric surface of the intermediate aquifer system in May 1986 near the end of the dry season when ground-water withdrawals are greatest and water levels are at their seasonal low. The altitude of the potentiometric surface ranges from about 120 feet above sea level in Polk County to less than 10 feet above sea level near the coast. The decline in the potentiometric surface from September 1985 to May 1986 ranged from about 1 to 20 feet and resulted from ground-water withdrawals. Largest declines were in south-central Polk, central Hardee, and north-central De Soto Counties. Smallest declines were in Charlotte County. 


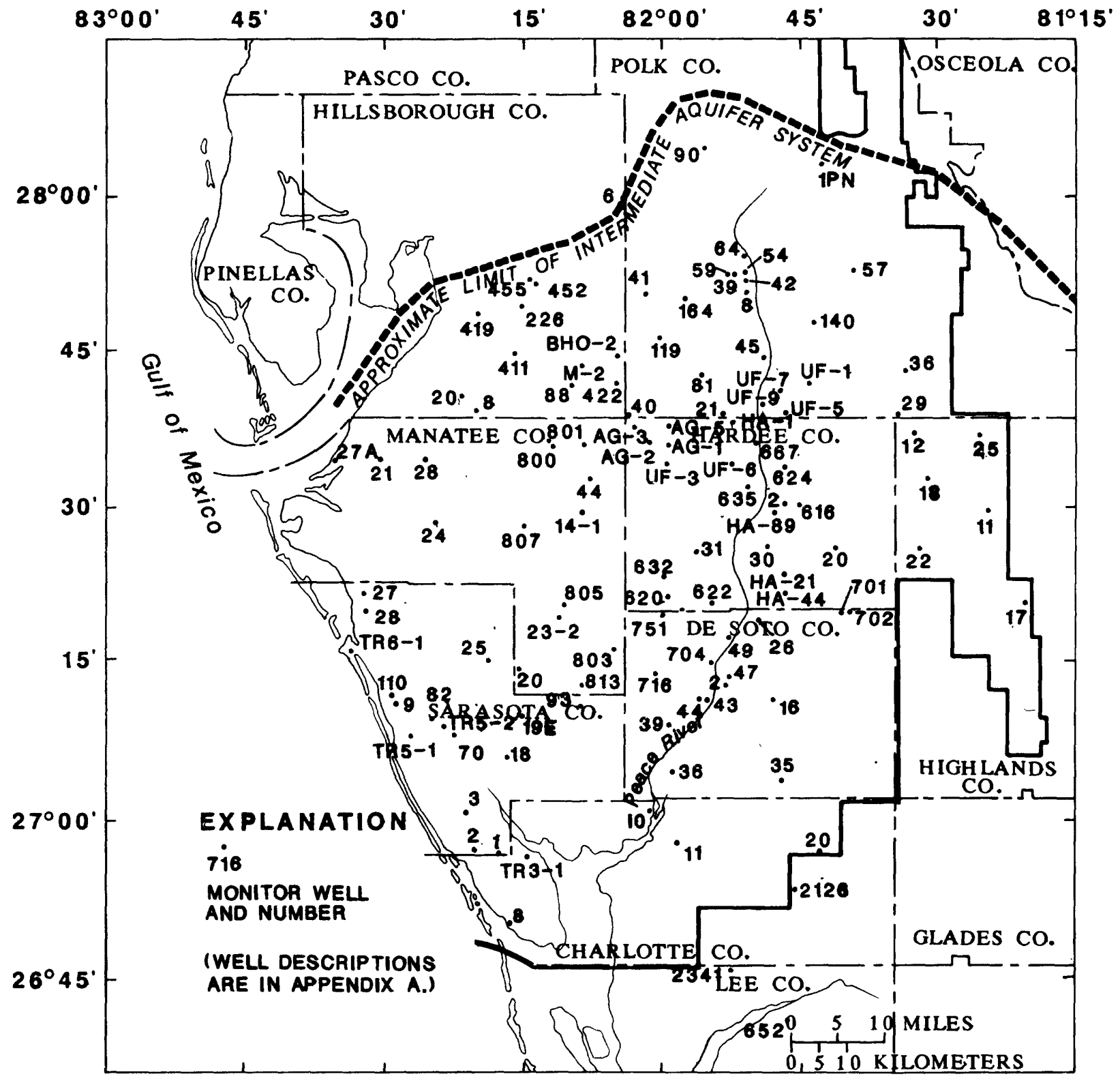

Figure 15.--Locations of wells in the intermediate aquifer system. 


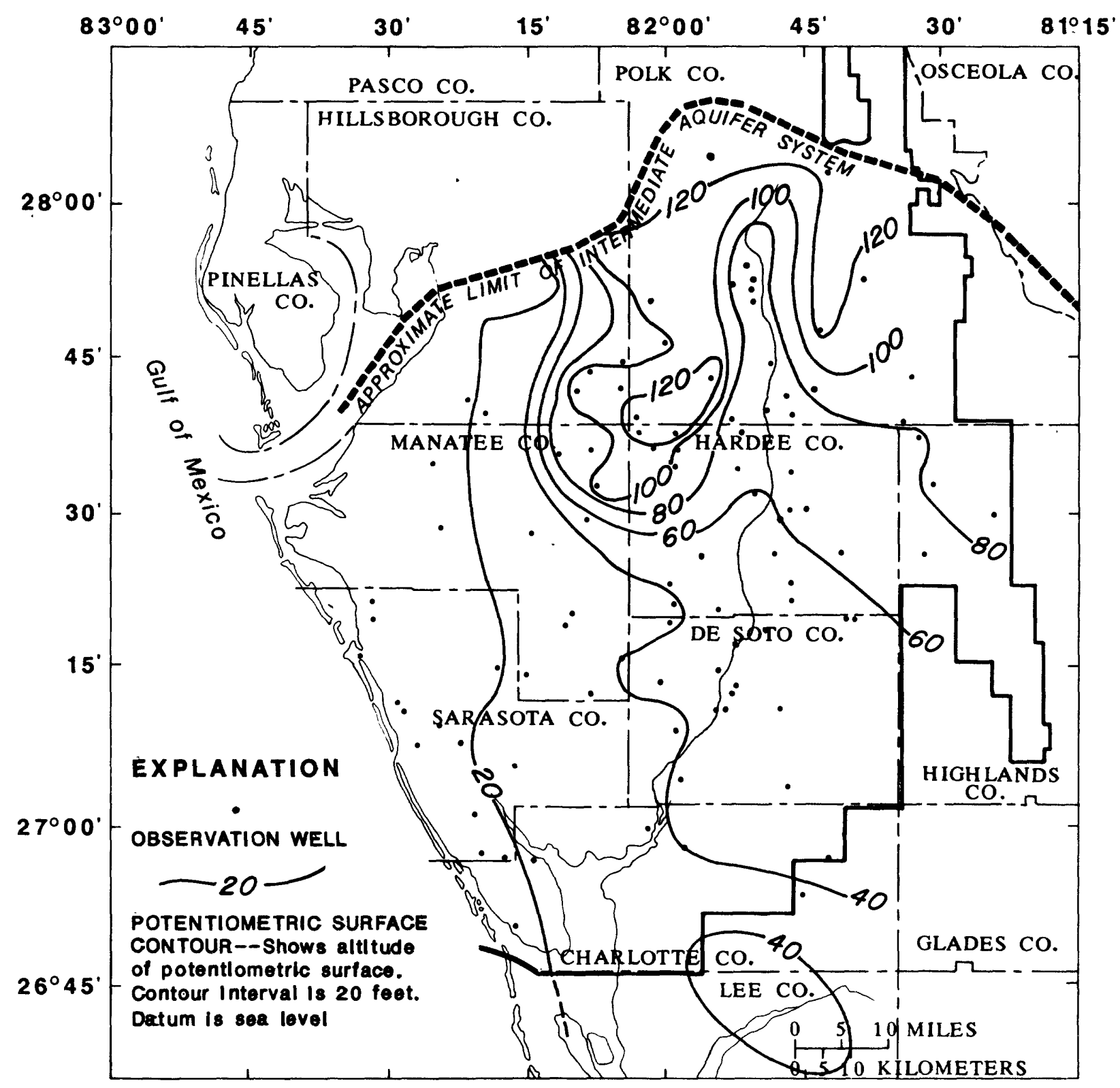

Figure 16.--Potentiometric surface of the intermediate aquifer system, September 1985. 


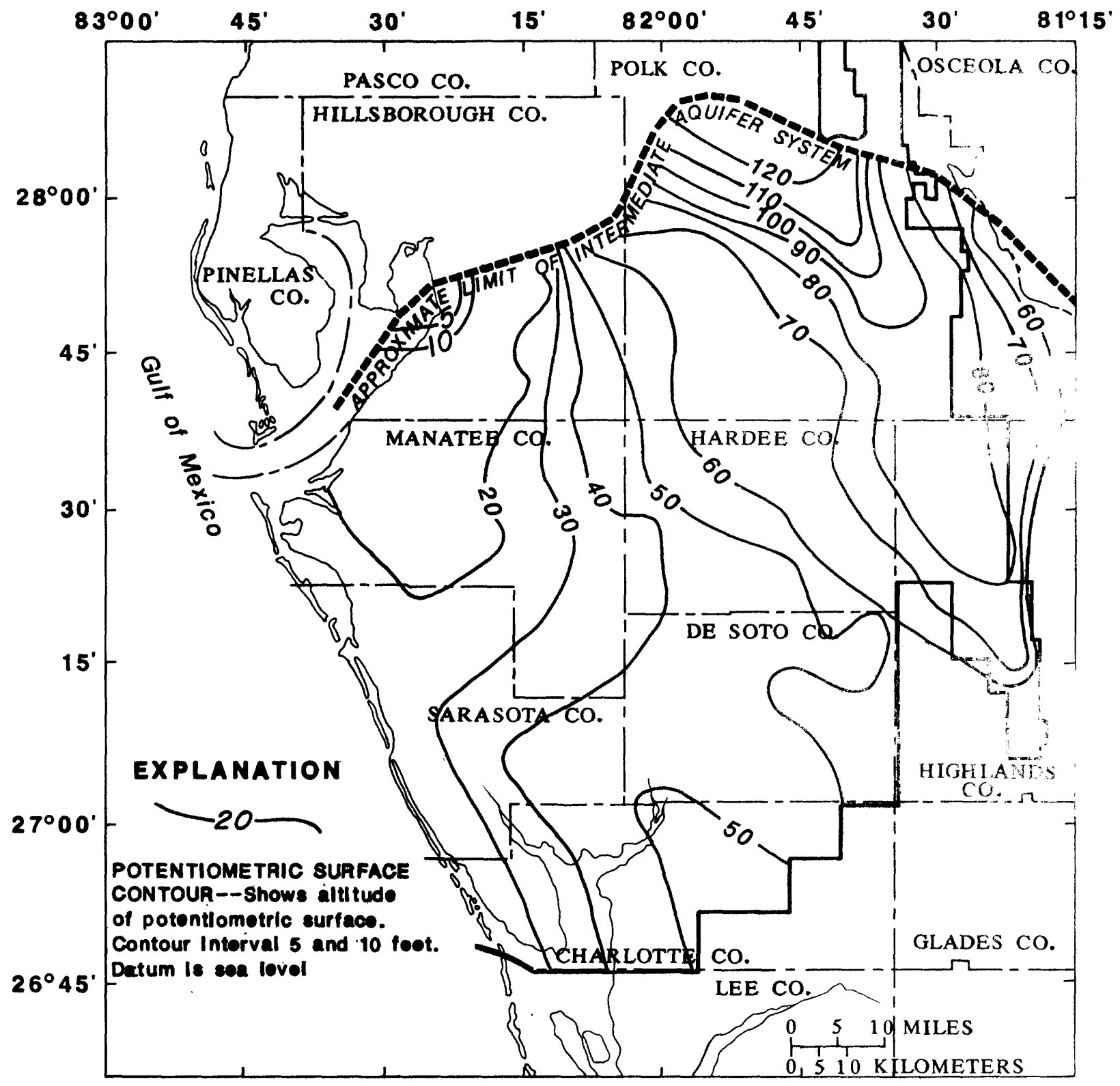

Figure 17.--Potentiometric surface of the Upper Floridan aquifer, September 1985. (Modified from Barr, 1985.) 


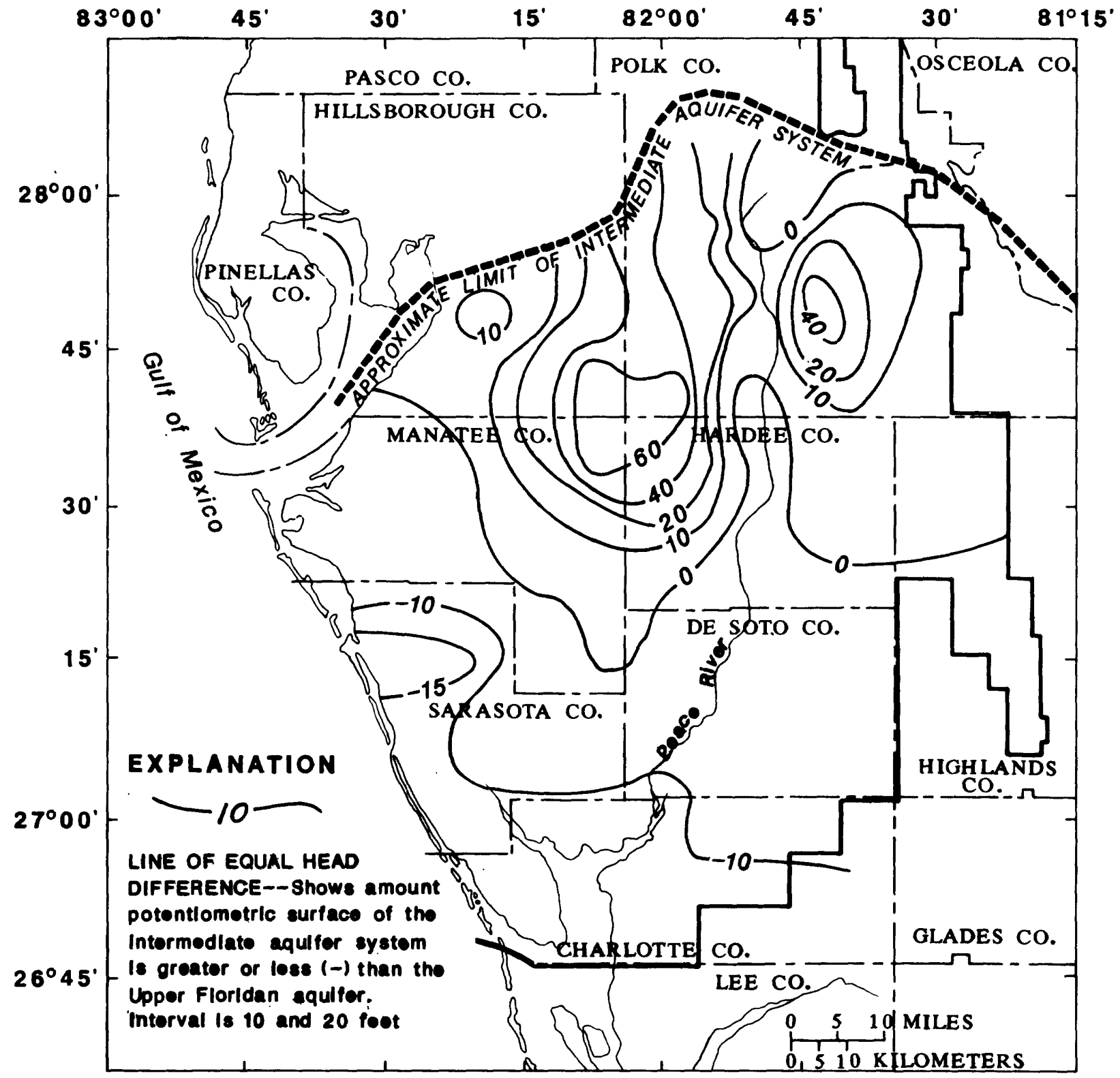

Figure 18.--Head difference between the potentiometric surfaces of the intermediate aquifer system and the underlying Upper Floridan aquifer, September 1985. 


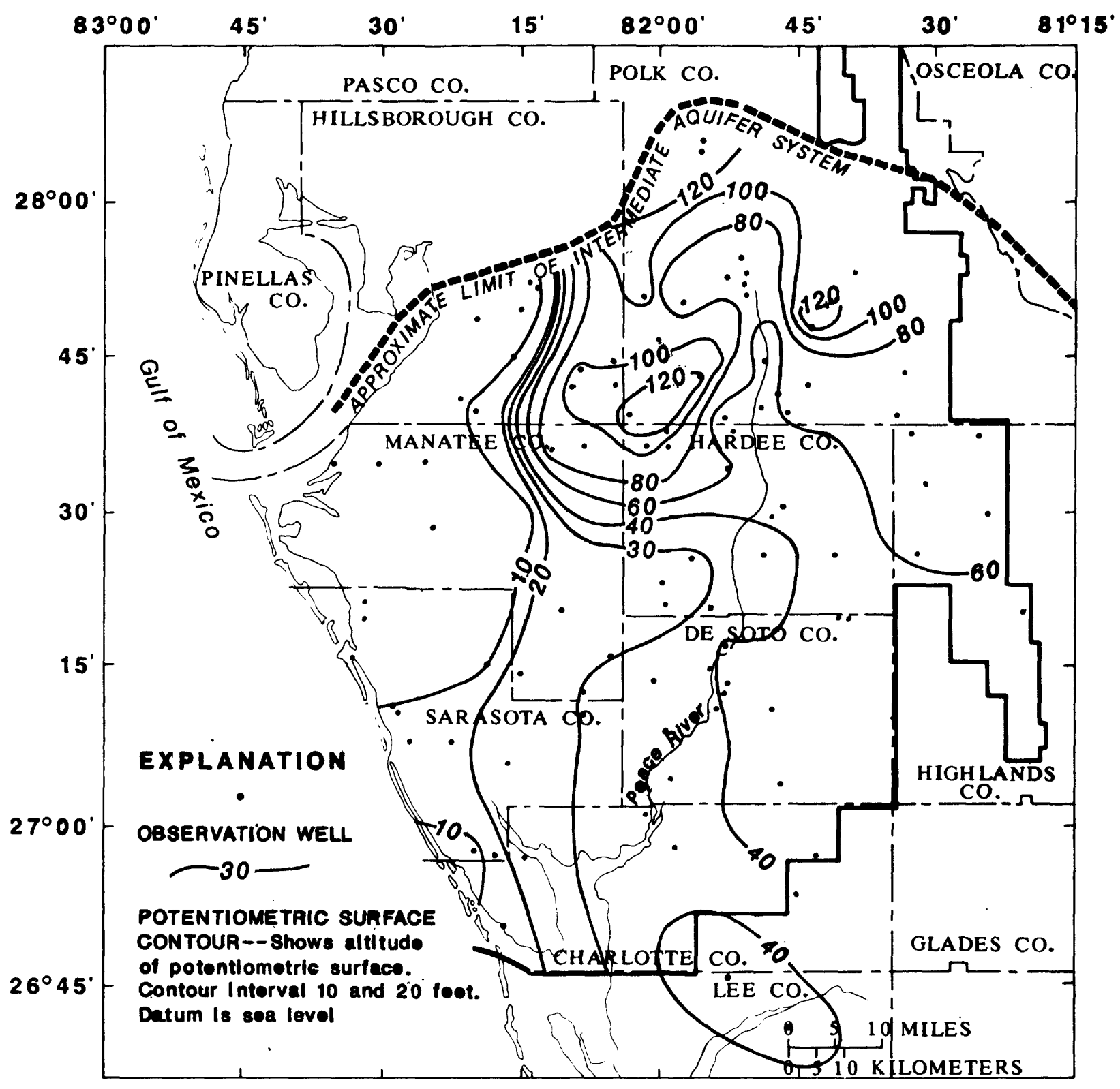

Figure 19.--Potentiometric surface of the intermediate aquifer system, May 1986. 
The potentiometric surface of the Upper Floridan aquifer in May 1986 is shown in figure 20. Head differences between the two aquifers are shown in figure 21. As in September 1985, the potentiometric surface of the intermediate aquifer system in May 1986 was greater than the potentiometric surface of the underlying Upper Floridan aquifer throughout the northern part of the study area. Head differences were greater in May 1986 than in September 1985 and the area where the intermediate aquifer system heads were higher extended further south. Head differences ranged from more than +100 feet in southwestern Polk County to about -10 feet in Charlotte County.

Large head differences between the Upper Floridan aquifer and the intermediate aquifer system in May 1986 in the northern half of the study area were caused by large ground-water withdrawals from the Upper Floridan aquifer for irrigation during the dry spring season. The potentiometric surface of the intermediate aquifer system was only slightly lower in May than in September because of relatively small ground-water withdrawals from the intermediate aquifer system for irrigation during the dry spring season.

The Southwest Florida Water Management District has drilled a network of monitoring wells at ROMP sites (Regional observation and Monitor-we11 Program). Locations of ROMP sites are shown in figure 22. Hydrographs of paired ROMP wells are shown in figures 23 through 31 and illustrate the head difference between the aquifer system throughout the study area. Monthly rainfall is also shown in these figures. The hydrographs show water-level responses to seasonal rainfall variations and ground-water withdrawals. Generally, water levels are highest at the end of the wet season (June through September) and lowest at the end of the dry season (April and May). The dry spring season is also the period of peak water use, and large ground-water withdrawals also contribute to the seasonal decline in water levels.

ROMP sites 57, 59, 40, and 45 in Polk County (figs. 23 through 26) and ROMP site 31 in Hardee County (fig. 27) show that the intermediate aquifer system has a potentiometric surface greater than that of the underlying Upper Floridan aquifer in the northern part of the study area. ROMP sites TR5-1 and TR5-2 in Sarasota County and TR3-1 in Charlotte County show that these gradients are reversed in the south as heads increase with depth (figs. 29 through 31).

Hydrographs at ROMP sites 45,31 , and 26 in southern Polk, central Hardee, and northern De Soto Counties show that small ( 1 to 4 feet) head differences and similar fluctuation patterns exist for wells in the intermediate aquifer system and wells in the Upper Floridan aquifer (figs. 25, 27, and 28). This suggests that leaky, fairly permeable confining beds allow relatively good connection between aquifers in the central part of the study area.

Hydrographs at ROMP sites 57 and 59 in central Polk County show a large head difference between aquifers (figs. 23 and 24). Water levels are 10 to 15 feet higher in the intermediate aquifer system than in the underlying Upper Floridan aquifer. This suggests that the confining beds between aquifers are relatively impermeable.

Hydrographs at ROMP site 40 in southwestern Polk County also show large head differences between aquifers (fig. 26). Water levels are 70 to 110 feet higher in the intermediate aquifer system than in the underlying Upper Floridan aquifer. 


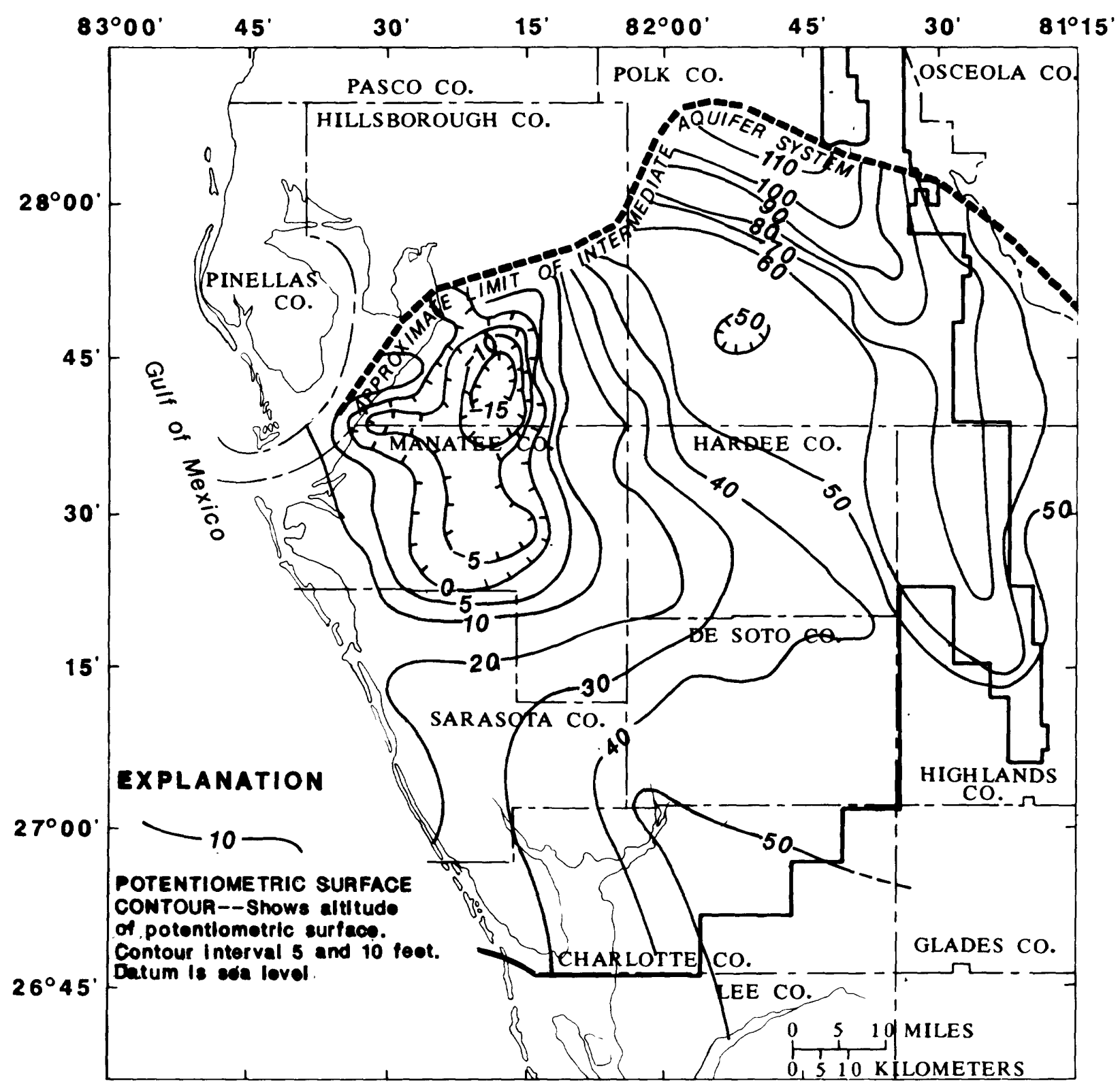

Figure 20.--Potentiometric surface of the Upper Floridan aquifer, May 1986. (Modified from Barr and Lewelling, 1986.) 


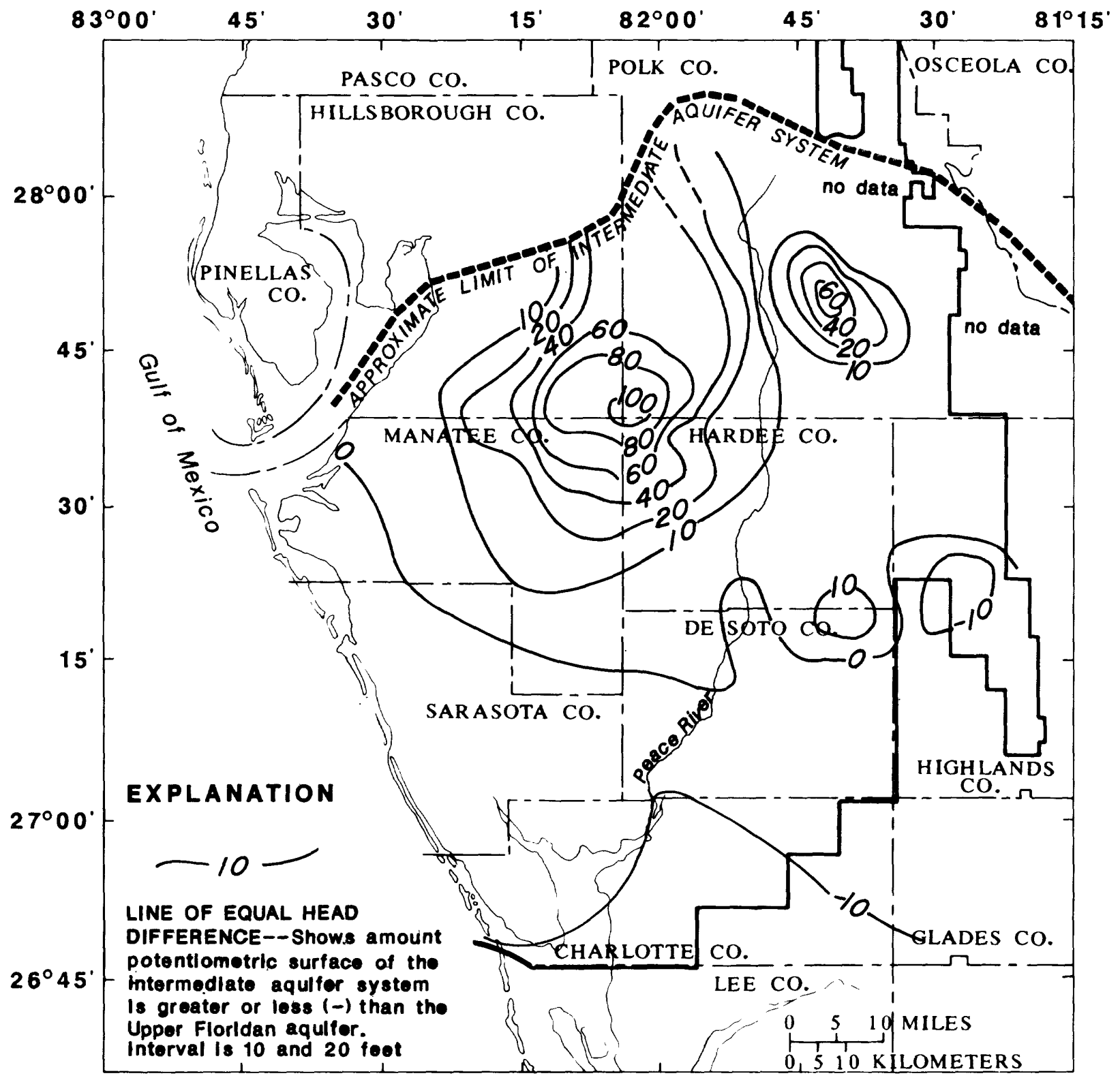

Figure 21.--Head difference between the potentiometric surfaces of the intermediate aquifer system and the underlying Upper Floridan aquifer, May 1986. 


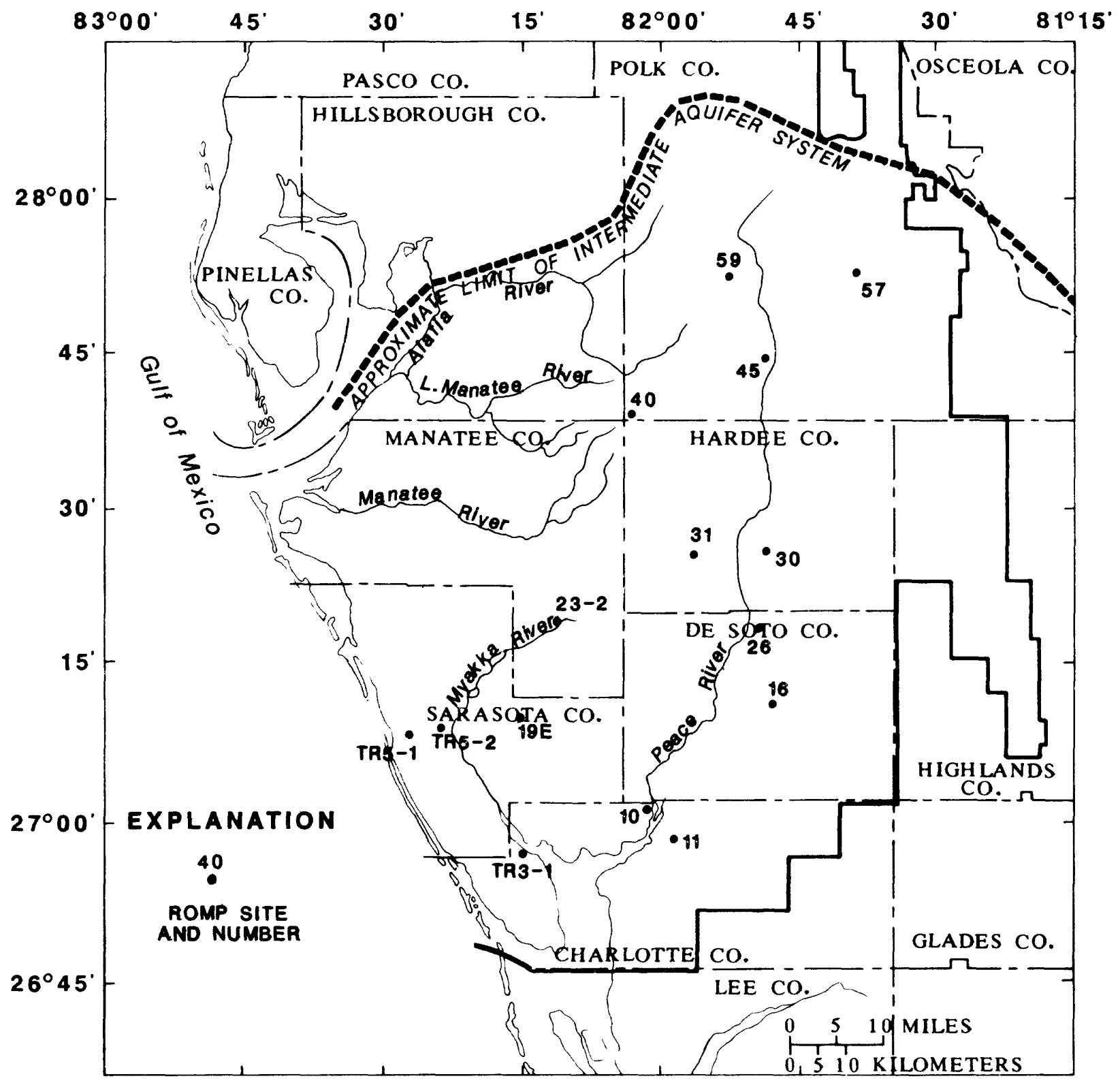

Figure 22.--Locations of Regional Observation and Monitor Well Program sites. 


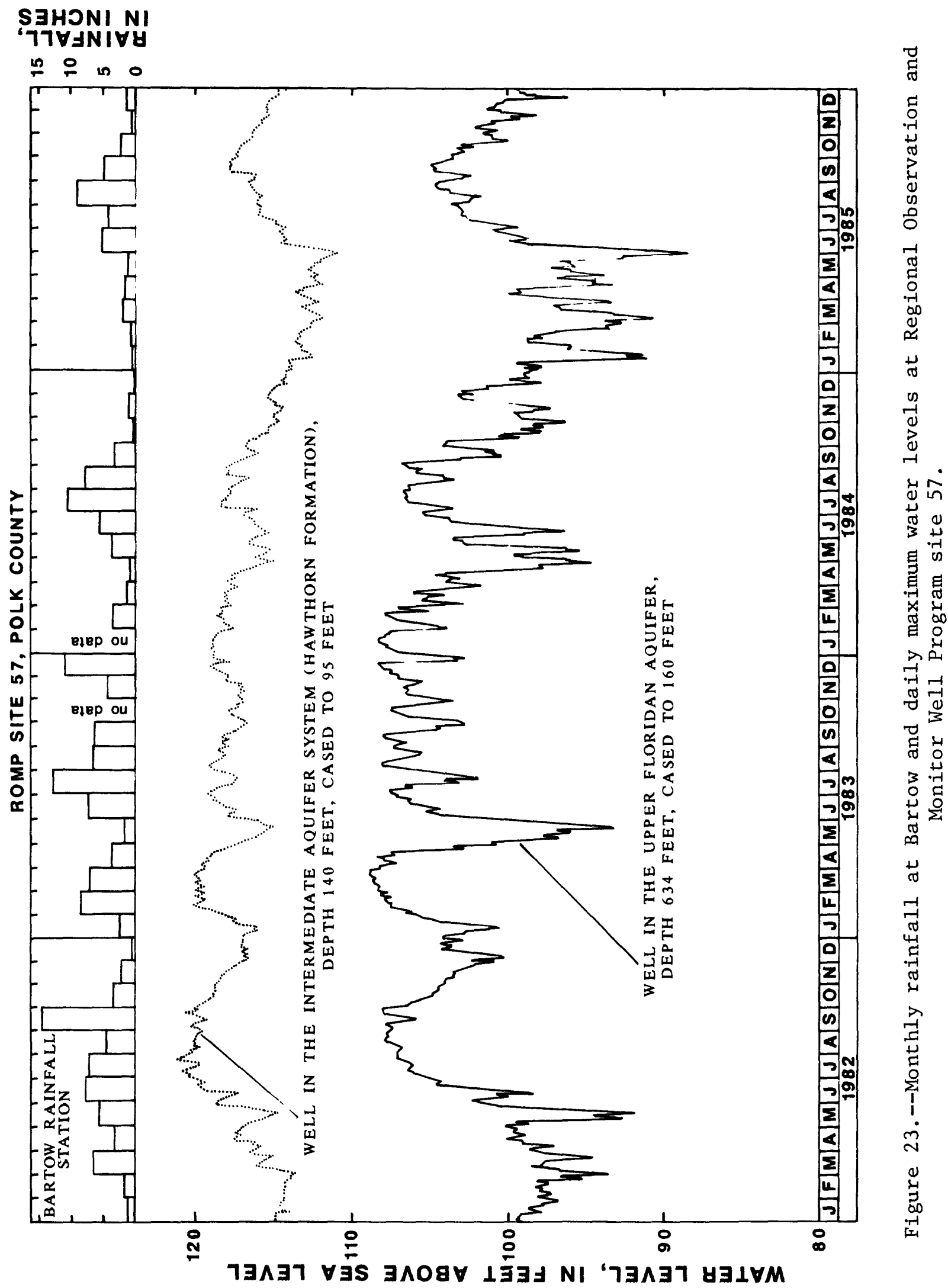




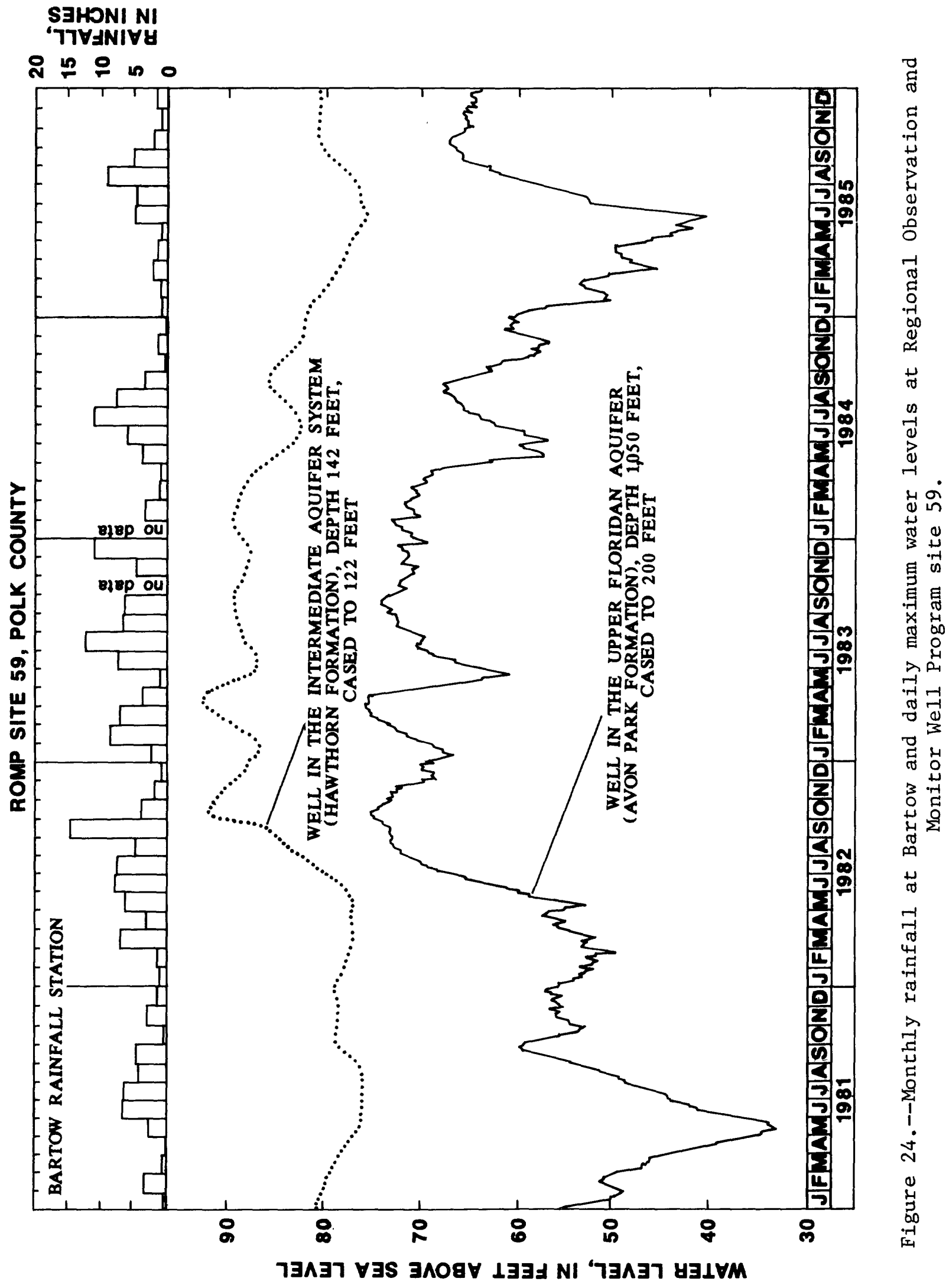




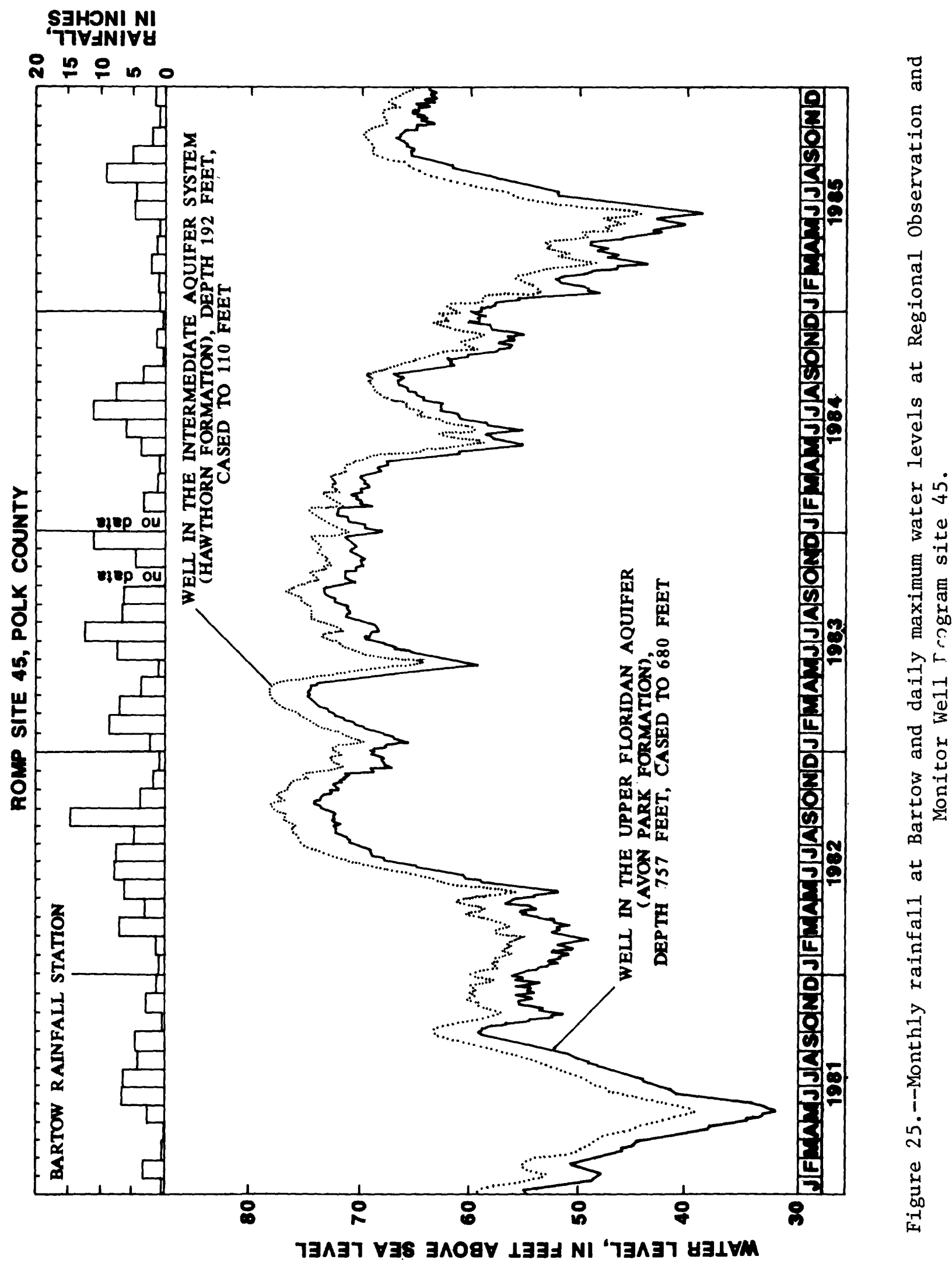




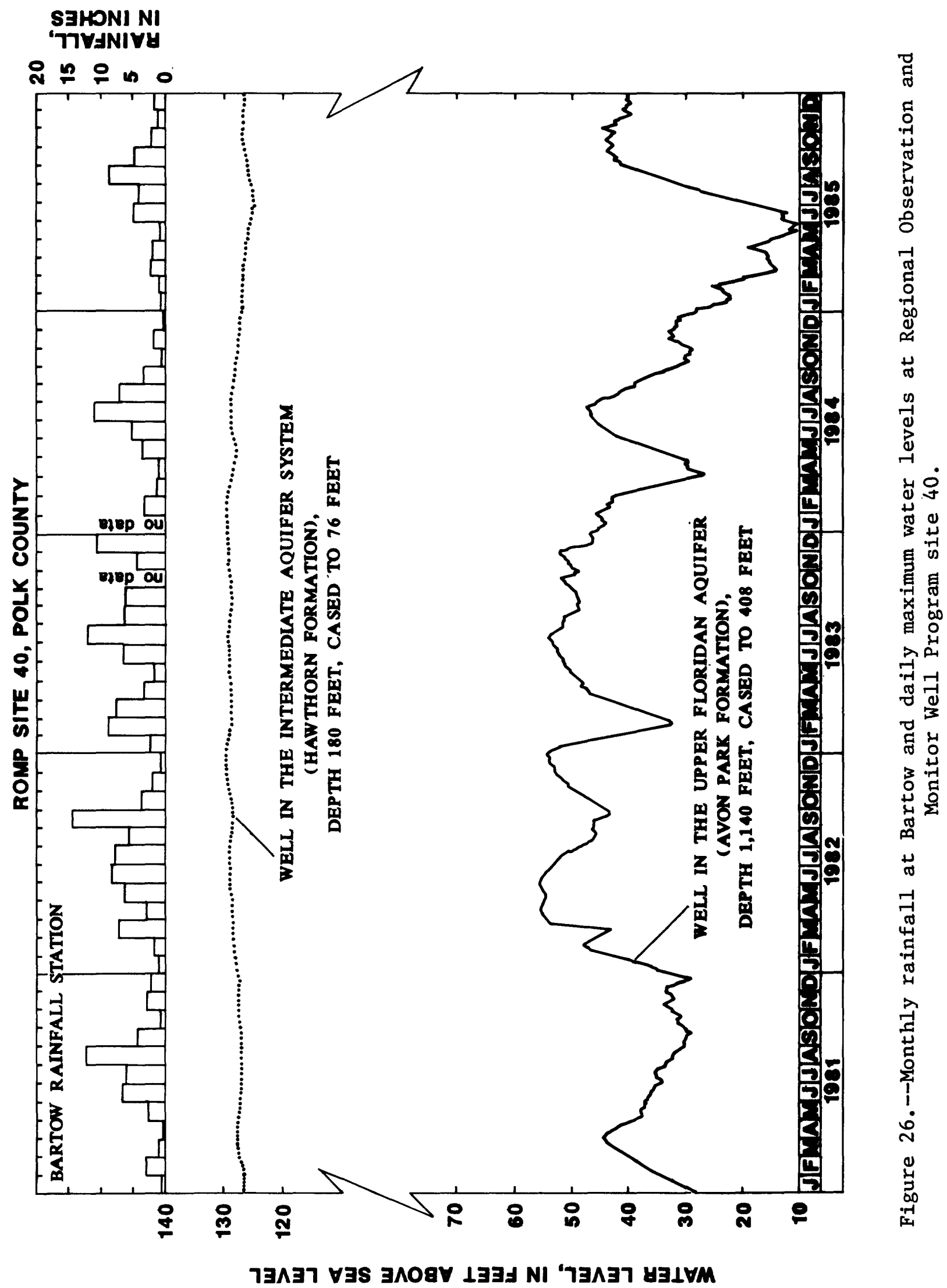




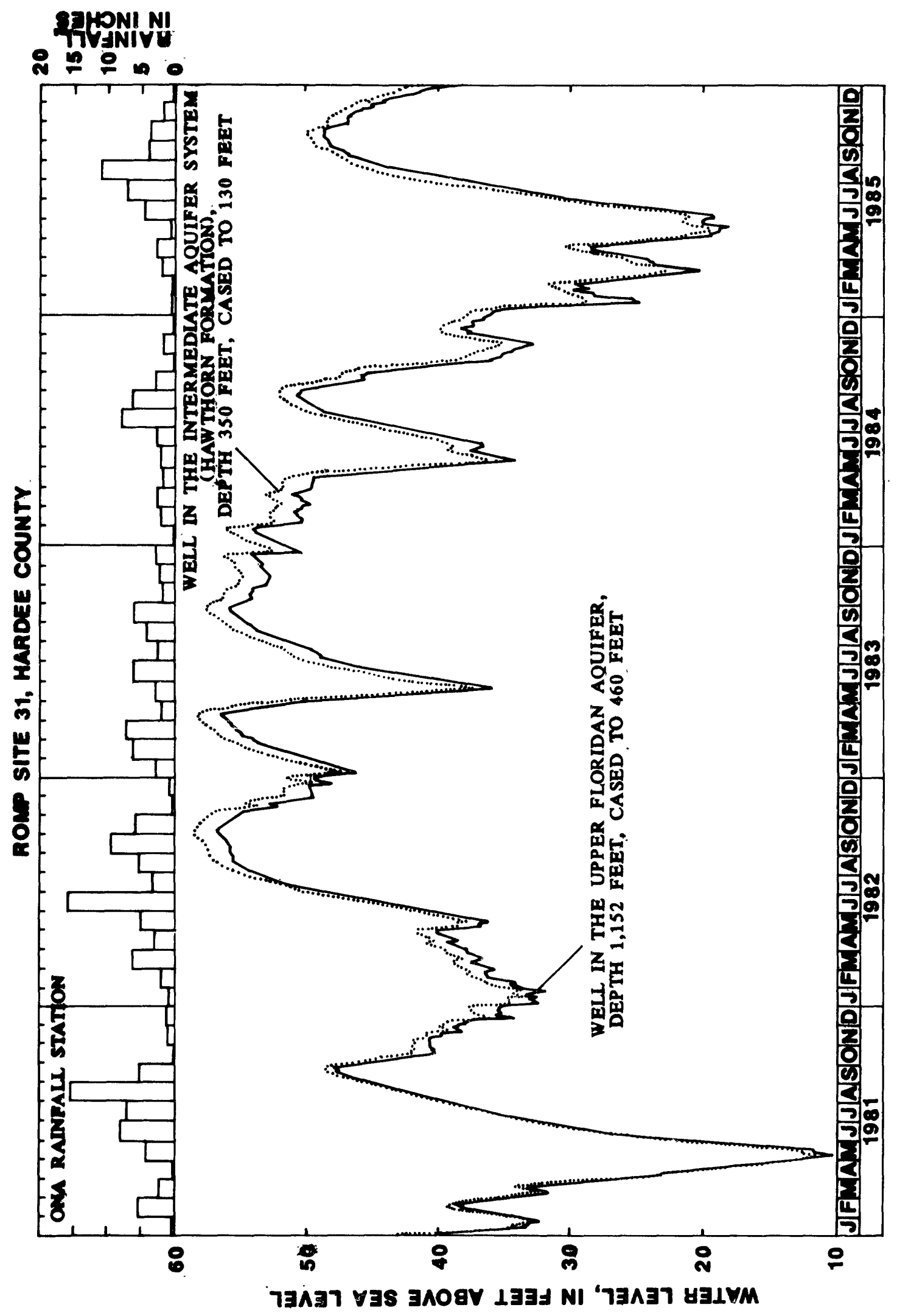

E



H

品

of

مै

$+$

o

o

ल

崩热

उ

星 晶

곰

ชั

D.

त्नન

要 3

पु

究些

志呈

곡

ช্

골

吉

$\sum_{1}^{0}$

N

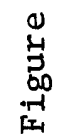




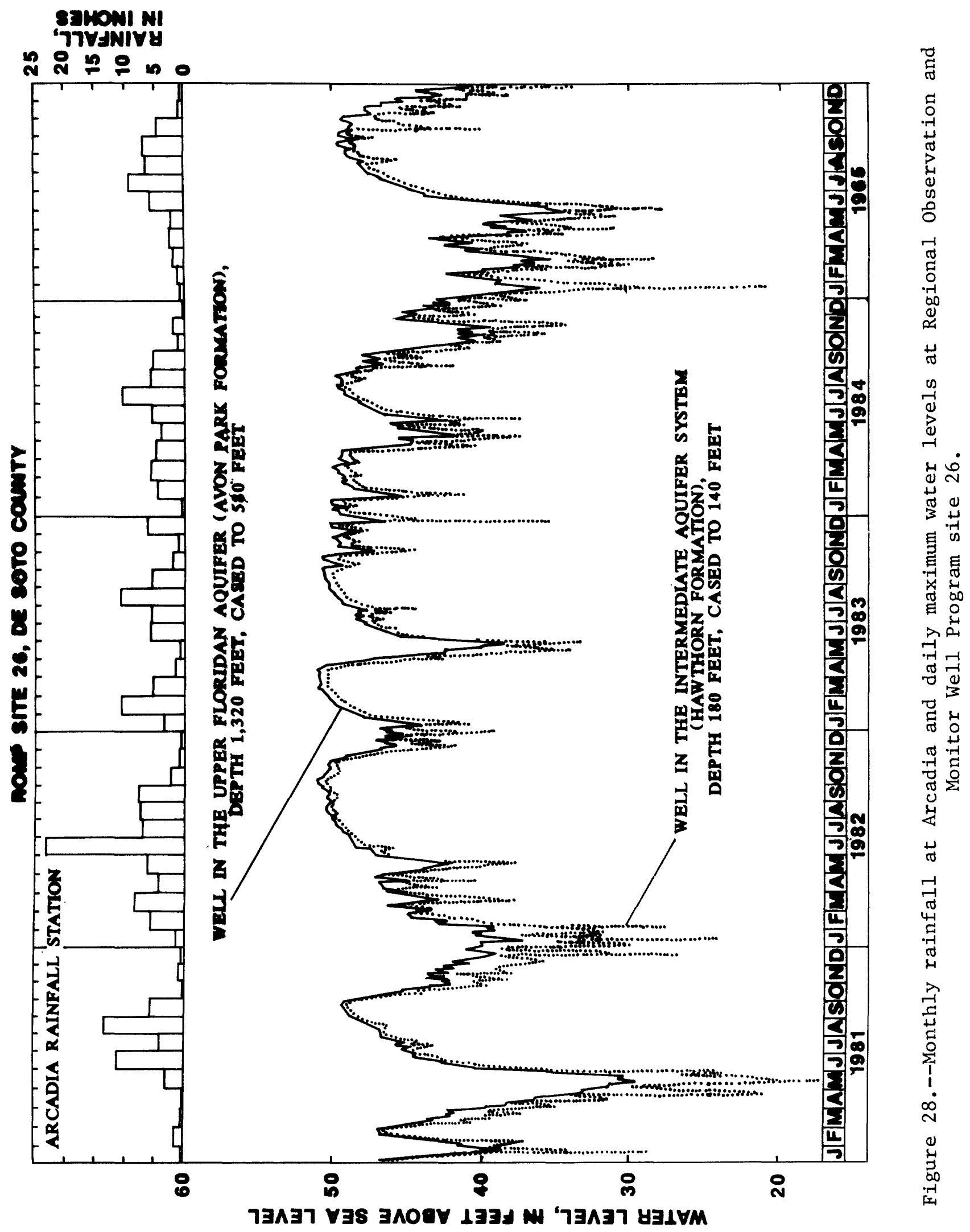




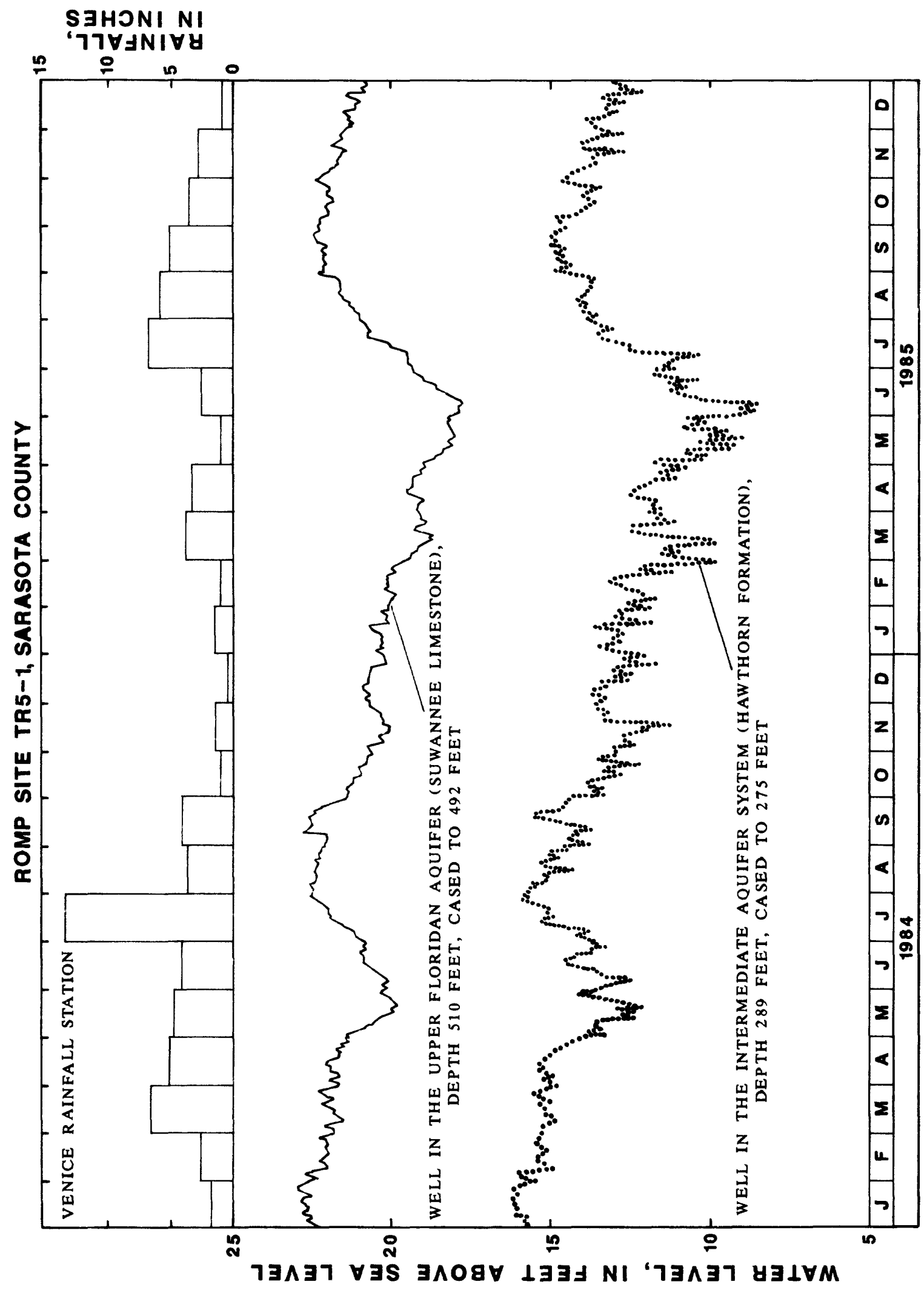

gृ

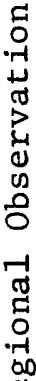

o

㫕

a

वे

म

㟧

3

灵

光

đั

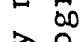

त्ते

శึ-

可

ฮै 옹

总

崩

 


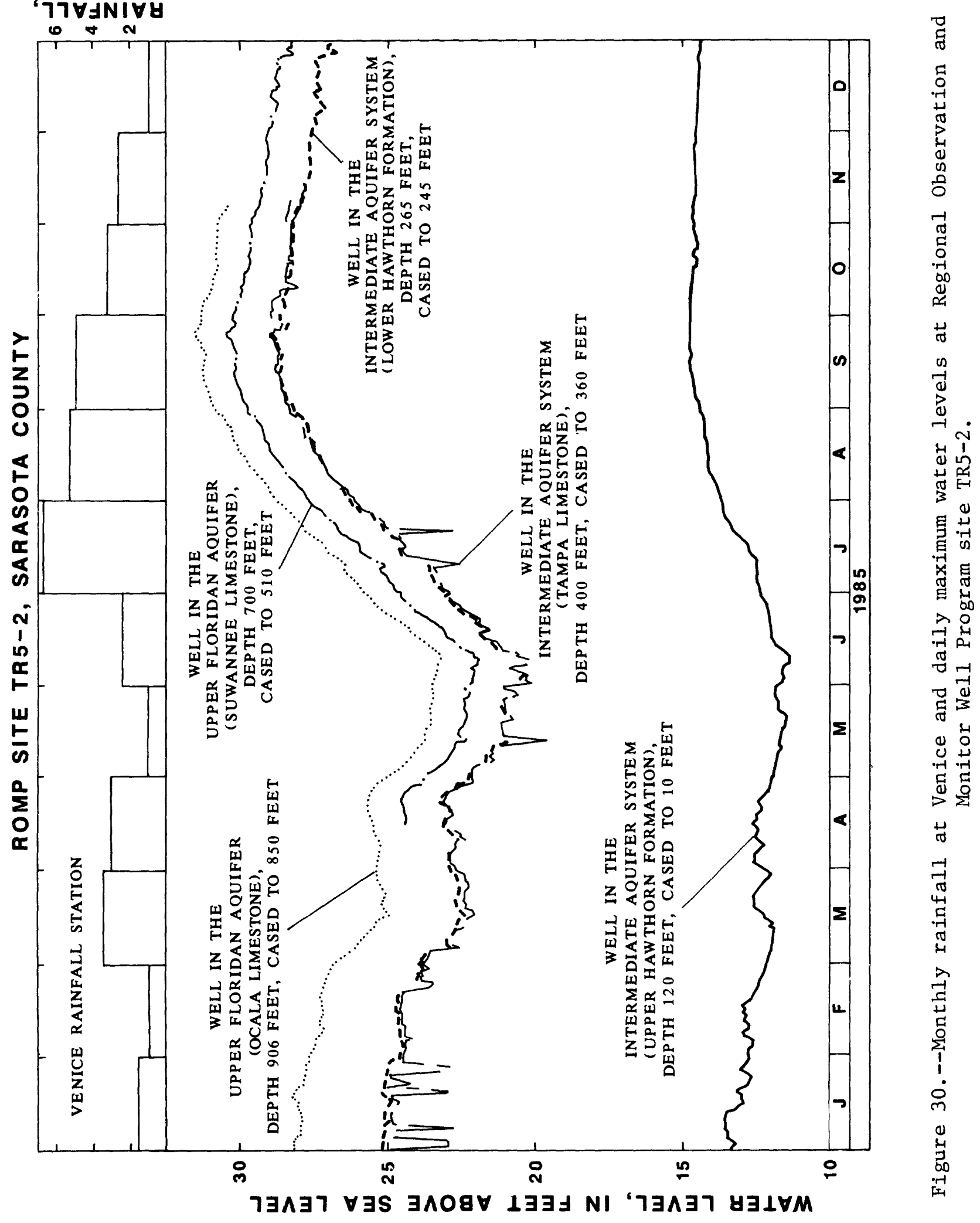




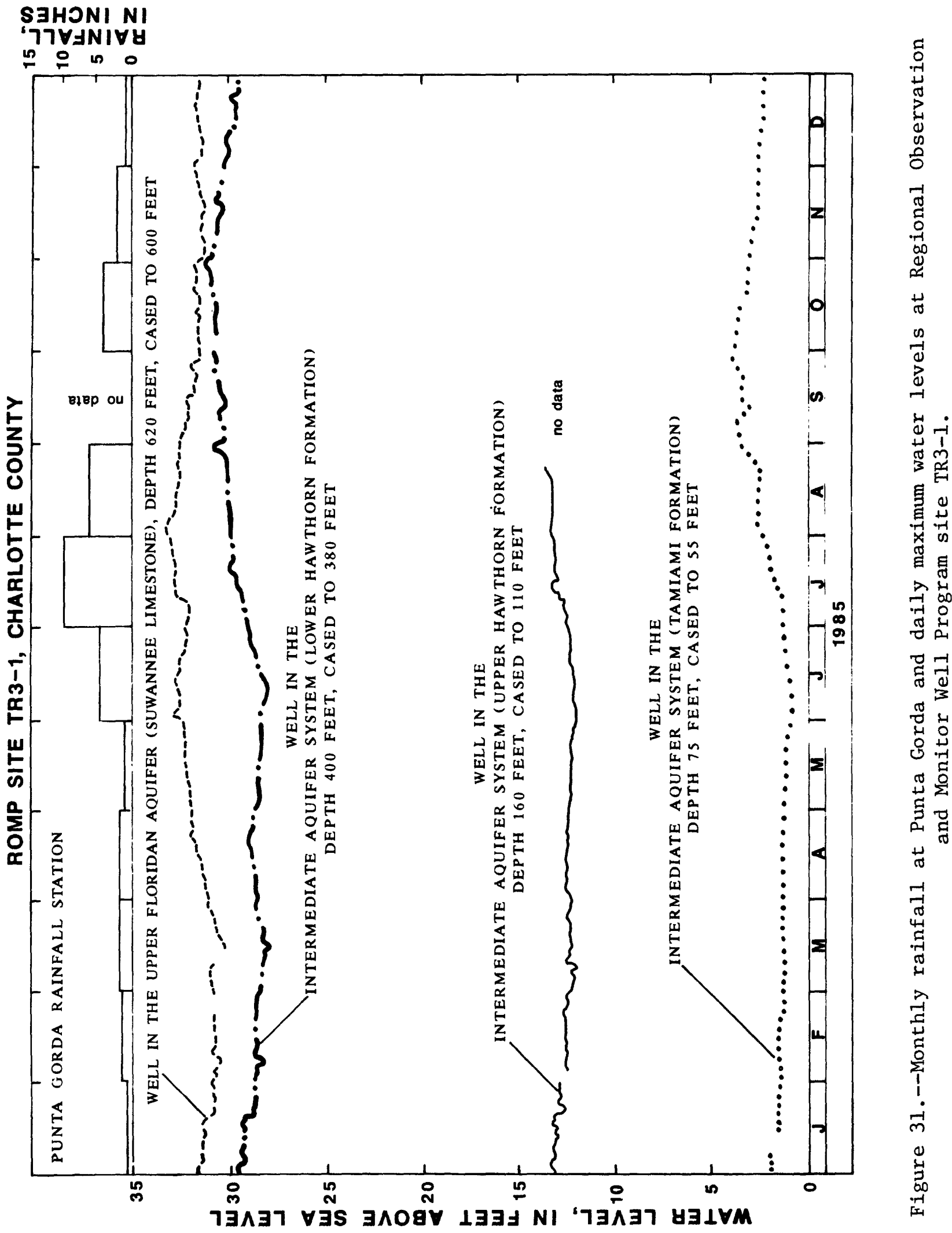


The confining beds are also relatively impermeable in the southern part of the study area where water levels are significantly lower in the intermediate aquifer system than in the Upper Floridan aquifer as shown in the hydrographs at ROMP sites TR5-1, TR5-2, and TR3-1 in Sarasota and Charlotte Counties (figs. 29 through 31). Hydrographs at ROMP sites TR5-2 and TR3-1 show water levels increasing with depth in three different zones within the intermediate aquifer system at each site.

\section{GROUND - WATER WITHDRAWAL}

Ground-water withdrawal data for the Southwest Florida Water Management District are collected cooperatively by the Southwest Florida Water Management District and the U.S. Geological Survey. A combined total of about 1,288 $\mathrm{Mgal} / \mathrm{d}$ of fresh ground water was withdrawn from the surficial, intermediate, and Upper Floridan aquifers in 1985 for irrigation, public and rural supply, and industrial use (Stieglitz, 1986). Of this total, an estimated $808 \mathrm{Mgal} / \mathrm{d}$ was withdrawn in the study area. Withdrawal data are not delineated by individual aquifers.

The Upper Floridan aquifer is by far the most productive aquifer and supplies more than 10 times the amount of water pumped from either the surficial aquifer system or the intermediate aquifer system in most of the study area. However, the importance of the Upper Floridan aquifer as a source of water diminishes as the water quality in the aquifer decreases in the southern and western parts of the study area where concentrations of dissolved solids, chloride and sulfate exceed $1,000,250$, and $250 \mathrm{mg} / \mathrm{L}$, respectively (Wolansky, $1983 ;$ p. 32). The saline water is the probable result of past marine inundations and subsequent mixing and water-rock reactions (Steinkampf, 1982, p. 1). In these areas, the intermediate aquifer system is the most important source of ground water for public supply because it has better water quality.

Following is an estimate of the amount of freshwater withdrawn from the intermediate aquifer system in 1985 in the study area and an explanation of the techniques used to make the estimate. Withdrawals outside of the Southwest Florida Water Management District boundary are not included in the estimate.

Estimates of water withdrawn from the intermediate aquifer system were based upon: (1) Southwest Florida Water Management District well construction and consumptive-use permitting files; (2) U.S. Geological Survey Ground-Water Site Inventory Files; (3) specific capacity and transmissivity data for various aquifers; and (4) data reported by previous investigators, such as Sutcliffe (1975), Wilson (1977), and Stieglitz (1986).

We11 construction was the primary factor for estimating water withdrawn from the intermediate aquifer system. Depth and casing of withdrawal wells in each county were estimated from well-construction data. The depth and casing data indicated from which aquifer or aquifers the well was producing water. In areas where wells were constructed with producing zones in more than one aquifer, the ratio of the specific capacities or transmissivities of the two aquifers from the site or a nearby site was used to estimate the proportion of water withdrawn from each aquifer. Information on sources of withdrawals reported by previous investigators also was used to estimate withdrawals from the system. 
An estimated $68.9 \mathrm{Mgal} / \mathrm{d}$ of water was withdrawn for all use categories in 1985 from the intermediate aquifer system in the Southwest Florida Water Management District (table 2). The largest withdrawal of ground water was for irrigation, about $38.8 \mathrm{Mgal} / \mathrm{d}$. Of this total, $15.0 \mathrm{Mgal} / \mathrm{d}$ was withdrawn in Charlotte County. The largest withdrawal of ground water from the system for al1 use categories was in Sarasota County, about 18.3 Mgal/d (Stieglitz, 1986).

Table 2.--Water withdrawn from the intermediate aquifer system, 1985

\begin{tabular}{|c|c|c|c|c|c|}
\hline \multirow[b]{2}{*}{ County } & \multicolumn{5}{|c|}{$\begin{array}{l}\text { Water withdrawn for indicated purpose, } \\
\text { in million gallons per day }\end{array}$} \\
\hline & $\begin{array}{l}\text { Public } \\
\text { supply }\end{array}$ & Rural & Industrial & Irrigation & Total \\
\hline $\begin{array}{l}\text { Charlotte }{ }^{1} \\
\text { De Soto } \\
\text { Hardee } \\
\text { Highlands }\end{array}$ & $\begin{array}{l}0.4 \\
.7 \\
0 \\
0\end{array}$ & $\begin{array}{l}2.0 \\
1.1 \\
1.2 \\
1.0\end{array}$ & $\begin{array}{l}0.0 \\
.1 \\
.4\end{array}$ & $\begin{array}{r}15.0 \\
2.0 \\
3.0 \\
3.6\end{array}$ & $\begin{array}{r}17.4 \\
3.9 \\
4.6 \\
4.6\end{array}$ \\
\hline $\begin{array}{l}\text { Hillsborough } \\
\text { Manatee } \\
\text { Polk } 1 \\
\text { Sarasota }\end{array}$ & $\begin{array}{c}0 \\
0 \\
0 \\
10.0\end{array}$ & $\begin{array}{r}1.5 \\
.3 \\
4.0 \\
3.1\end{array}$ & $\begin{array}{l}0.1 \\
4.2 \\
0\end{array}$ & $\begin{array}{l}.5 \\
6.2 \\
3.3 \\
5.2\end{array}$ & $\begin{array}{r}2.1 \\
6.5 \\
11.5 \\
18.3\end{array}$ \\
\hline Total & 11.1 & 14.2 & 4.8 & 38.8 & 68.9 \\
\hline
\end{tabular}

1 Includes only data for parts of the county that are in the Southwest Florida Water Management District.

\section{Public Supply}

The public supply category includes all water distributed by publicsupply water systems to households, industry, agriculture, and other purposes (Duerr and Sohm, 1983). A total of about $97.8 \mathrm{Mgal} / \mathrm{d}$ of ground water was withdrawn for public supply from all aquifers in the study area in 1985 (Stieglitz, 1986). Of this total, about $11.1 \mathrm{Mgal} / \mathrm{d}$ was withdrawn from the intermediate aquifer system (table 2). The largest withdrawals from the intermediate aquifer system for public supply were in Sarasota County, about $10.0 \mathrm{Mgal} / \mathrm{d}$.

\section{Rural Supply}

The rural supply category includes all water supplied to households that are not supplied by large (withdrawing more than 100,000 gal/d) public-supply systems. This includes households that have their own water supply and households that are supplied by small public-supply systems. Well diameters generally range from 2 to 4 inches. 
Ground water withdrawn for rural use from all aquifers in the study area in 1985 averaged about $29.8 \mathrm{Mgal} / \mathrm{d}$ (Stieglitz, 1986). Of this total, about 14.2 Mgal/d was withdrawn from the intermediate aquifer system (table 2). The largest rural water withdrawals were from the intermediate aquifer system, about $4 \mathrm{Mgal} / \mathrm{d}$, and occurred in Polk County.

\section{Industrial Supply}

The industrial supply category includes water used by industries that supply their own water. Data do not include water sold to industries by public-supply systems.

Ground water withdrawn for industrial purposes from all aquifers in the study area in 1985 averaged about $159.7 \mathrm{Mgal} / \mathrm{d}$ (Stieglitz, 1986). Of this total, about $4.8 \mathrm{Mgal} / \mathrm{d}$ was withdrawn from the intermediate aquifer system (table 2). Polk County had the largest withdrawal from the intermediate aquifer system in this category, about $4.2 \mathrm{Mgal} / \mathrm{d}$, most of which was withdrawn for phosphate mining, chemical processing, and citrus processing.

\section{Irrigation Supply}

The irrigation supply category includes water withdrawn by irrigators from private wells and does not include water supplied by public-supply systems. Irrigation water use is generally not metered and estimates of water use for irrigation are the least accurate of all water-use data. For a more complete discussion of irrigation water use see Duerr and Sohm (1983) and Stieglitz (1986).

Ground water withdrawn for irrigation from all aquifers in the study area in 1985 averaged about $521 \mathrm{Mgal} / \mathrm{d}$ (Stieglitz, 1986). Of this total, about $38.8 \mathrm{Mgal} / \mathrm{d}$ was withdrawn from the intermediate aquifer system (table 2). Irrigation withdrawals were largest in Charlotte County, $15 \mathrm{Mgal} / \mathrm{d}$, most of which was for citrus and vegetable irrigation.

\section{SUMMARY}

The study area includes the southern part of the Southwest Florida Water Management District, an area of about $4,700 \mathrm{mi}^{2}$. The area is characterized by a low-lying coastal plain bordered by sand-covered ridges along the north and east that are more than 150 feet above sea level. The climate is warm with humid summers and mild, moderately dry winters. The average annual rainfall of five stations in southwest Florida for the period 1915 to 1976 was 53.1 inches.

Principal hydrogeologic units are the surficial aquifer system, the intermediate aquifer system, and the Floridan aquifer system. The surficial aquifer system overlies the intermediate aquifer system and consists of Holocene and Pleistocene age deposits containing sand, clayey sand, shell, shelly marl, and some phosphorite. Thickness ranges from about 25 feet near the coast and low-1ying areas to about 250 feet in Highlands County. Trans missivity ranges from about 1,100 to about $8,000 \mathrm{ft}^{2} / \mathrm{d}$. 
The intermediate aquifer system includes all water-bearing units and confining material between the overlying surficial aquifer system and the underlying Floridan aquifer system. The intermediate aquifer system consists of three hydrogeologic units: (1) a sandy clay and clayey sand confining unit in the lower part that lies directly on the Floridan aquifer system; (2) an aquifer system that consists of one, two, or three water-bearing units (aquifers) composed primarily of sand and carbonate rocks; and (3) a sandy clay, clay, and marl confining unit in the upper part that separates the water-bearing unit in the intermediate aquifer system from the overlying surficial aquifer system.

The top of the intermediate aquifer system ranges from more than 100 feet below sea level in Highlands County to more than 100 feet above sea level in Polk County. The thickness of the intermediate aquifer system ranges from less than 100 feet in central Hillsborough and northern Polk Counties to more than 800 feet in southern Charlotte County.

Total transmissivity of aquifers within the intermediate aquifer system ranges from less than $200 \mathrm{ft}^{2} / \mathrm{d}$ where the permeable deposits are thin to about $13,000 \mathrm{ft}^{2} / \mathrm{d}$ in the carbonate section near the Peace River. Leakance of the confining beds within the intermediate aquifer system ranges from $1 \times 10^{-7}$ to $4 \times 10^{-4}(\mathrm{ft} / \mathrm{d}) / \mathrm{ft}$.

The underlying Floridan aquifer system is defined as a vertically continuous sequence of carbonate rocks of generally high permeability that are of Tertiary age, that are hydraulically connected to each other in varying degrees, and whose permeability is several orders of magnitude greater than that of the rocks that bound the system above and below.

The Floridan aquifer system consists of the Upper and Lower Floridan aquifers separated by a "tight" middle confining unit. The middle unit and Lower Floridan aquifer generally contain saltwater. In most reports on the hydrology of southwest Florida, the term "Floridan aquifer" has been applied to the water-bearing rocks herein referred to as the Upper Floridan aquifer. It is the major source of fresh ground water for most of southwest Florida. Transmissivity of the Upper Floridan aquifer in the study area ranges from about $30,000 \mathrm{ft}^{2} / \mathrm{d}$ at the gulf coast where the freshwater zone is thin to about 400,000 $\mathrm{ft}^{2} / \mathrm{d}$ in eastern De Soto and Hardee Counties.

A comparison of the potentiometric surface of the intermediate aquifer system and the underlying Upper Floridan aquifer shows that in the northern part of the study area, heads in the intermediate aquifer system are higher than heads in the underlying Upper Floridan aquifer. Water is transmitted downward through the confining unit and recharges the Upper Floridan aquifer. The gradient in head reverses in the southern part of the study area where the underlying Upper Floridan aquifer has a higher head than the head in the intermediate aquifer system. There, water is transmitted upward through the confining unit and recharges the intermediate aquifer system.

The potentiometric surface of the intermediate aquifer system is general1y higher than the water level in the surficial aquifer system in the lowlying areas near the Peace River. As a result, in these areas, ground water moves upward from the intermediate aquifer system into the surficial aquifer system. 
The Upper Floridan aquifer is by far the most productive aquifer and supplies more than 10 times the amount of water pumped from either the surficial aquifer system or the intermediate aquifer system in most of the study area. However, the importance of the Upper Floridan aquifer as a source of water diminishes as the water quality in the aquifer decreases in the southern and western parts of the study area where concentrations of dissolved solids, chloride and sulfate exceed $1,000,250$, and $250 \mathrm{mg} / \mathrm{L}$, respectively. In these areas the importance of the intermediate aquifer system as a source of water increases.

In 1985, an estimated $808 \mathrm{Mgal} / \mathrm{d}$ of freshwater was withdrawn in the study area from the surficial and intermediate aquifer systems and Upper Floridan aquifer for irrigation, public and rural supply, and industrial use. of this total, an estimated $68.9 \mathrm{Mga} 1 / \mathrm{d}$ was withdrawn from the intermediate aquifer system. Sarasota County used the most water from the system for all use categories, about $18.3 \mathrm{Mgal} / \mathrm{d}$.

\section{SELECTED REFERENCES}

Barr, G.L., 1985, Potentiometric surface of the Upper Floridan aquifer, westcentral Florida, September 1985: U.S. Geological Survey Open-File Report $85-679,1$ sheet.

Barr, G.L., and Lewelling, B.R., 1986, Potentiometric surface of the Upper Floridan aquifer, west-central Florida, May 1986: U.S. Geological Survey Open-File Report 86-409, 1 sheet.

Bergendah1, M.H., 1956, Stratigraphy of parts of De Soto and Hardee Counties, Florida: U.S. Geological Survey Bulletin 1030-B, p. 65-97.

Bishop, E.W., 1956, Geology and ground-water resources of Highlands County, Florida: Florida Geological Survey Report of Investigations 15, $115 \mathrm{p}$.

-... 1960, Freshwater resources of Sarasota County, Florida: Sarasota County Commission Engineering Report, 35 p.

Brown, D.P., 1982, Water resources and data network assessment of the Manasota basin, Manatee and Sarasota Counties, Florida: U.S. Geological Survey Water-Resources Investigations $82-37,80 \mathrm{p}$.

-... 1983, Water resources of Manatee County, Florida: U.S. Geological Survey Water-Resources Investigations 81-74, $112 \mathrm{p}$.

Buono, Anthony, and Rutledge, A.T., 1979, Configuration of the top of the Floridan aquifer, Southwest Florida Water Management District and adjacent areas: U.S. Geological Survey Water-Resources Investigations OpenFile Report 78-34, 1 sheet.

Buono, Anthony, Spechler, R.M., Barr, G.L., and Wolansky, R.M., 1979, Generalized thickness of the confining bed overlying the Floridan aquifer, Southwest Florida Water Management District: U.S. Geological Survey Water-Resources Investigations Open-File Report 79-1171, 1 sheet.

Corral, M.A., Jr., and Wolansky, R.M., 1984, Generalized thickness and configuration of the top of the intermediate aquifer, west-central Florida: U.S. Geological Survey Water-Resources Investigations Report $84-4018,1$ sheet.

Dames and Moore, 1979, Consumptive use permit application supporting report, Little Payne Phosphate Mine, Polk and Hardee Counties, Florida, for USS Agri-Chemicals: Consultant's report in files of the Southwest Florida Water Management District. 
Duerr, A.D., and Sohm, J.E., 1983, Estimated water use in southwest Florida, 1981, and summary of annual water use, 1970, 1975, and 1977-81: U.S. Geological Survey Open-File Report 83-45, 75 p.

Duerr, A.D., and Wolansky, R.M., 1986, Hydrogeology of the surficial and intermediate aquifers of central Sarasota County, Florida: U.S. Geological Survey Water-Resources Investigations Report 86-4068, $48 \mathrm{p}$.

Eppert, H.C., 1966, Stratigraphy of the upper Miocene deposits in Sarasota County, Florida: Tulane Studies in Geology, v. 4, no. 2, p. 49-61.

Florida Department of Environmental Regulation, 1982, Public drinking water systems: Chapter 17-22 in Florida Administrative Code.

Franks, B.J. (ed.), 1982, Principal aquifers in Florida: U.S. Geological Survey Water-Resources Investigations 82-255, 4 sheets.

Geraghty and Miller, Inc., 1974, A reconnaissance appraisal of the water potential of the upper artesian aquifer at the Verna well field, Sarasota, Florida: City of Sarasota Engineering Report, $35 \mathrm{p}$.

.... 1975a, Ground water resources of the Verna well field, Sarasota, Florida: City of Sarasota Engineering Report, $30 \mathrm{p}$.

.... 1975b, Connector well feasibility study on the Phillips Petroleum Company property, De Soto and Manatee Counties, Florida: Consultant's report for Phillips Petroleum Company in files of the Southwest Florida Water Management District, $25 \mathrm{p}$.

-... 1978, Hydrologic effects of developing 15 MGD of water from the Floridan aquifer in the Pine Level area, De Soto and Manatee Counties, Florida: Consultant's report for Phillips Petroleum Company in files of the Southwest Florida Water Management District, $200 \mathrm{p}$.

.... 1980, Hydrogeologic investigation of the upper aquifer systems in the Venice Gardens area, phase I and II: Venice Gardens Utility Corporation Engineering Report, $34 \mathrm{p}$.

.... 1981, MacArthur Tract hydrologic and water-supply investigation, phase I: Southwest Florida Water Management District Engineering Report, $45 \mathrm{p}$.

-... 1982, Ground-water development potential, Snover Waterway, Sarasota County, Florida: Consultant's report for General Development Utilities, incorporated in files of the Southwest Florida Water Management District.

Heath, R.C., and Smith, P.C., 1954, Ground-water resources of Pinellas County, Florida: Florida Geological Survey Report of Investigations 12, $139 \mathrm{p}$.

Hutchinson, C.B., 1978, Appraisal of shallow ground-water resources and management alternatives in the upper Peace and eastern Alafia River basins, Florida: U.S. Geological Survey Water-Resources Investigations $77-124,57 \mathrm{p}$.

...-1982, Assessment of the interconnection between Tampa Bay and the Floridan aquifer, Florida: U.S. Geological Survey Water-Resources Investigations $82-54,60 \mathrm{p}$.

-... 1984, Hydrogeology of the Verna well-field area and management alternatives for improving yield and quality of water, Sarasota County, Florida: U.S. Geological Survey Water-Resources Investigations Report 84-4006, $53 \mathrm{p}$.

Joyner, B.F., and Sutcliffe, H., Jr., 1976, Water resources of the Myakka River basin area, southwest Florida: U.S. Geological Survey WaterResources Investigations 76-58, $87 \mathrm{p}$.

Kaufman, M.I, and Dion, N.P., 1968, Ground-water resources data of Charlotte, De Soto, and Hardee Counties, Florida: Florida Bureau of Geology Information Circular 53, 22 p.

LaMoreaux, P.E., and Associates, 1979, Supporting report for consumptive use permit, Farmland Industries, Inc., Hardee County property: Consultant's report in files of the Southwest Florida Water Management District, $98 \mathrm{p}$. 
Lindh and Associates, 1969, Test well study--proposed new well field, raw water supply, Englewood Water District: Englewood Water District Engineering Report, 40 p.

Lohman, S.W., 1972, Ground-water hydraulics: U.S. Geological Survey Professional Paper $708,70 \mathrm{p}$.

Menke, C.G., Meredith, E.W., and Wetterhall, W.S., 1961, Water resources of Hillsborough County, Florida: Florida Geological Survey Report of Investigations $20,101 \mathrm{p}$.

-.. 1964, Water resources records of Hillsborough County, Florida: Florida Geological Survey Information Circular 44, $95 \mathrm{p}$.

Miller, J.A., 1982a, Thickness of the Tertiary limestone aquifer system, southeastern United States: U.S. Geological Survey Water-Resources Investigations Open-File Report 81-1124, 1 sheet.

.... 1982b, Geology and configuration of the base of the Tertiary limestone aquifer system, southeastern United States: U.S. Geological Survey Water-Resources Investigations Open-File Report 81-1176, 1 sheet.

-... 1982c, Geology and configuration of the top of the Tertiary limestone aquifer system, southeastern United States: U.S. Geological Survey Water-Resources Investigations Open-File Report 81-1178, 1 sheet.

-... 1982d, Thickness of the upper permeable zone of the Tertiary limestone aquifer system, southeastern United States: U.S. Geological Survey Water-Resources Investigations Open-File Report 81-1179, 1 sheet.

-... 1982e, Configuration of the base of the upper permeable zone of the Tertiary limestone aquifer system, southeastern United States: U.S. Geological Survey Water-Resources Investigations Open-File Report $81-1177,1$ sheet.

-... 1986, Hydrogeologic framework of the Floridan aquifer system in Florida and in parts of Georgia, South Carolina, and Alabama: U.S. Geological Survey Professional Paper 1403-B, $91 \mathrm{p}$.

Palmer, C.E., and Bone, L.P., 1977, Some aspects of rainfall deficits in westcentral Florida, 1961-1976: Southwest Florida Water Management District Hydrometeorological Report No. 1, $19 \mathrm{p}$.

Parker, G.G., Ferguson, G.E., Love, S.K., and others, 1955, Water resources of southeastern Florida, with special reference to geology and ground water of the Miami area: U.S. Geological Survey Water-Supply Paper 1255, $965 \mathrm{p}$.

Peek, H.M., 1958, Ground-water resources of Manatee County, Florida: Florida Geological Survey Report of Investigations 18, $99 \mathrm{p}$.

-... 1959a, The artesian water of the Ruskin area of Hil1sborough County, Florida: Florida Geological Survey Report of Investigations 21, $96 \mathrm{p}$.

... 1959b, Record of wells in the Ruskin area of Hillsborough County, Florida: Florida Geological Survey Information Circular 22, 85 p.

Reynolds, Smith, and Hills, Inc., 1974, Engineering and financial analysis of water supply alternatives: Venice Gardens Utility Corporation Engineering Report, $34 \mathrm{p}$.

-... 1975, Phase I report, ground water development program, Venice Gardens, Florida: Venice Gardens Utility Corporation Engineering Report, $40 \mathrm{p}$.

Robertson, A.F., 1973, Hydrologic conditions in the Lakeland Ridge area of Polk County, Florida: Florida Bureau of Geology Report of Investigations $64,54 \mathrm{p}$.

Robertson, A.F., and Mills, L.R., 1974, Ground-water withdrawals in the upper Peace and upper Alafia River basins, Florida: Florida Bureau of Geology Map Series 67 . 
Robertson, A.F., Mills, L.R., and Parsons, D.C., 1978, Ground water withdrawn for municipal, industrial, and irrigation use in the upper Peace and Alafia River basins, west-central Florida, 1970-74: U.S. Geological Survey Open-File Report 78-29, 59 p.

Russell and Axon, Inc., 1965, Water supply facilities, city of Venice, Florida: City of Venice Engineering Report, $38 \mathrm{p}$.

Ryder, P.D., 1982, Digital model of predevelopment flow in the Tertiary limestone (Floridan) aquifer system in west-central Florida: U.S. Geological Survey Water-Resources Investigations 81-64, 61 p.

.... 1985, Hydrology of the Floridan aquifer system in west-central Florida: U.S. Geological Survey Open-File Report 84-611, 92 p.

Scott, T.M., and MacGill, P.L., 1981, The Hawthorn Formation of central Florida: Florida Bureau of Geology Report of Investigations 91, $107 \mathrm{p}$.

Sinclair, W.C., Stewart, J.W., Knutilla, R.L., Gilboy, A.E., and Miller, R.L., 1985, Types, features, and occurrence of sinkholes in the karst of westcentral Florida: U.S. Geological Survey Water-Resources Investigations Report 85-4126, $81 \mathrm{p}$.

Smally, Wellford and Nalvin, Inc., 1963, Water supplies of Sarasota County: Sarasota County Engineering Report, 122 p.

-..- 1977, Manasota 1iterature assessment study: Sarasota County Engineering Report, $120 \mathrm{p}$.

Smith and Gillespie, Inc., 1960, Interim report on ground-water studies for Sarasota, Florida: City of Sarasota Engineering Report, 20 p.

... 1975, Ground water resources available for raw water supply facilities, water works system - city of Sarasota, Florida: City of Sarasota Engineering Report, 25 p.

Southeastern Geological Society, 1986, Hydrogeological units of Florida: Florida Geological Survey Special Publication 28, 9 p.

Sproul, C.R., Boggess, D.H., and Woodard, H.J., 1972, Saline-water intrusion from deep artesian sources in the McGregor Isles area of Lee County, Florida: Florida Bureau of Geology Information Circular 75, $30 \mathrm{p}$.

Steinkampf, W.C., 1982, Origins and distribution of saline ground waters in the Floridan aquifer in coastal southwest Florida: U.S. Geological Survey Water-Resources Investigations Report 82-4052, 34 p.

Stewart, H.G., Jr., 1963, Records of wells and other water-resources data in Polk County, Florida: Florida Geological Survey Information Circular 38, $144 \mathrm{p}$.

-... 1966, Ground-water resources of Polk County, Florida: Florida Geological Survey Report of Investigations $44,170 \mathrm{p}$.

Stewart, J.W., Goetz, C.L., and Mills, L.R., 1978, Hydrogeologic factors affecting the availability and quality of ground water in the Temple Terrace area, Hillsborough County, Florida: U.S. Geological Survey Water-Resources Investigations 78-4, $38 \mathrm{p}$.

Stieglitz, E.H., 1986, Estimated water use in the Southwest Florida Water Management District, 1985: Southwest Florida Water Management District Report, $53 \mathrm{p}$.

Stringfield, V.T., 1933a, Ground-water resources of Sarasota County, Florida: Florida Geological Survey, in 23rd-24th Annual Report, p. 131-194.

...-1933b, Exploration of artesian wells in Sarasota County, Florida: Florida Geological Survey, in 23rd-24th Annual Report, p. 195-227.

-... 1936, Artesian water in the Florida peninsula: U.S. Geological Survey Water-Supply Paper 773-C, p. 115-195.

-.. 1966, Artesian water in Tertiary limestone in the southeastern states: U.S. Geological Survey Professional Paper 517, 226 p. 
Sutcliffe, Horace, Jr., 1975, Appraisal of the water resources of Charlotte County, Florida: Florida Bureau of Geology Report of Investigations 78, $53 \mathrm{p}$.

Sutcliffe, Horace, Jr., and Joyner, B.F., 1968, Test well exploration in the Myakka River basin area, Florida: Florida Geological Survey Information Circular 56, $61 \mathrm{p}$.

Sutcliffe, Horace, Jr., and Thompson, T.H., 1983, Occurrence and use of ground water in the Venice-Englewood area, Sarasota and Charlotte Counties, Florida: U.S. Geological Survey Open-File Report 82-700, 59 p.

Wells, S.W., 1969, Water resources survey, Port Charlotte, Florida: General Development Utilities, Inc., Engineering Report, 30 p.

White, W.A., 1970, The geomorphology of the Florida peninsula: Florida Bureau of Geology Bulletin 51, 164 p.

William F. Guyton and Associates, 1976, Hydraulics and water quality: Consultant's report prepared for Swift Agricultural Chemicals Corporation in files of the Southwest Florida Water Management District.

Wilson, W.E., 1977, Ground-water resources of De Soto and Hardee Counties, Florida: Florida Bureau of Geology Report of Investigations 82, $102 \mathrm{p}$.

-... 1982, Estimated effects of projected ground-water withdrawals on movement of the saltwater front in the Floridan aquifer, 1976-2000, westcentral Florida: U.S. Geological Survey Water-Supply Paper 2189, 24 p.

Wolansky, R.M., 1983, Hydrogeology of the Sarasota-Port Charlotte area, Florida: U.S. Geological Survey Water-Resources Investigations Report $82-4089,48 \mathrm{p}$.

Wolansky, R.M., Barr, G.L., and Spechler, R.M., 1979, Generalized configuration of the bottom of the Floridan aquifer, Southwest Florida Water Management District: U.S. Geological Survey Water-Resources Investigations Open-File Report 79-1490, 1 sheet.

-.. 1980, Configuration of the top of the highly permeable dolomite zone of the Floridan aquifer, Southwest Florida Water Management District: U.S. Geological Survey Water-Resources Investigations Open-File Report 80-433, 1 sheet.

Wolansky, R.M., and Corral, M.A., Jr., 1985, Aquifer tests in west-central Florida, 1952-76: U.S. Geological Survey Water-Resources Investigations Report 84-4044, $127 \mathrm{p}$.

Wolansky, R.M., Spechler, R.M., and Buono, Anthony, 1979, Generalized thickness of the surficial deposits above the confining bed overlying the Floridan aquifer, Southwest Florida Water Management District: U.S. Geological Survey Water-Resources Investigations Open-File Report $79-1071,1$ sheet. 
APPENDIX A: Records of Monitor Wells in the

[We11 locations are shown in figure 14. Water-leve1

\begin{tabular}{|c|c|c|c|}
\hline $\begin{array}{l}\text { Well } \\
\text { No. }\end{array}$ & $\begin{array}{c}\text { Identification } \\
\text { No. }\end{array}$ & County & Owner or name \\
\hline 8 & 265017082153701 & Charlotte & U.S. Geological Survey no. 3 \\
\hline 2126 & 265321081442601 & Charlotte & Babcock \\
\hline TR3 - 1 & 265638082130704 & Charlotte & ROMP TR3-1 mid-Hawthorn \\
\hline 20 & 265656081414701 & Charlotte & Tropica1 Rivers Grove 1 \\
\hline 11 & 265837081561101 & Charlotte & ROMP 11 Hawthorn \\
\hline 10 & 270152082002803 & Charlotte & ROMP 10 Hawthorn \\
\hline 35 & 270339081464401 & De Soto & Nichols Ranch (FBG D-39) \\
\hline 36 & 270417081575601 & De Soto & G. V. Russel (FBG D-307) \\
\hline 39 & 270858081582201 & De Soto & Nunez \\
\hline 43 & 271109081541901 & De Soto & Minute Maid (FBG D-68) \\
\hline $\begin{array}{l}44 \\
16\end{array}$ & $\begin{array}{l}271113081543301 \\
271115081462702\end{array}$ & $\begin{array}{l}\text { De Soto } \\
\text { De Soto }\end{array}$ & $\begin{array}{l}\text { Minute Maid (FBG D-69) } \\
\text { ROMP } 16 \text { Hawthorn }\end{array}$ \\
\hline 2 & 271308081522601 & De Soto & Arcadia well 2 at tank \\
\hline 47 & 271332081520901 & De Soto & City of Arcadia \\
\hline 16 & 271407082000401 & De Soto & Hollingsworth \\
\hline 704 & 271517081542201 & De Soto & Bartcher 704 \\
\hline 49 & 271623081520101 & De Soto & Camp Chanyahtah (Girls) \\
\hline 26 & 271757081493003 & De Soto & ROMP 26 Hawthorn \\
\hline $\begin{array}{l}751 \\
702\end{array}$ & $\begin{array}{l}272014081595701 \\
272015081392701\end{array}$ & $\begin{array}{l}\text { De Soto } \\
\text { De Soto }\end{array}$ & $\begin{array}{l}\text { Hollingsworth } 751 \\
\text { Amoco } 2 \text { (oil test we11) }\end{array}$ \\
\hline
\end{tabular}


Intermediate Aquifer System in Southwest Florida

altitude in feet above or below (-) sea level]

\begin{tabular}{|c|c|c|c|c|c|c|}
\hline $\begin{array}{l}\text { We11 } \\
\text { use }\end{array}$ & $\begin{array}{c}\text { We11 } \\
\text { depth } \\
\text { (feet) }\end{array}$ & $\begin{array}{l}\text { Casing } \\
\text { depth } \\
\text { (feet) }\end{array}$ & $\begin{array}{l}\text { Casing } \\
\text { diameter } \\
\text { (inches) }\end{array}$ & $\begin{array}{l}\text { Land- } \\
\text { surface } \\
\text { altitude } \\
\text { (feet) }\end{array}$ & Date & $\begin{array}{l}\text { Water- } \\
\text { leve } 1 \\
\text { altitude } \\
\text { (feet) }\end{array}$ \\
\hline Observation & 413 & 346 & 4 & 4 & $\begin{array}{l}9-20-85 \\
5-15-86\end{array}$ & $\begin{array}{l}16.4 \\
15.0\end{array}$ \\
\hline Unused & 404 & 42 & 4 & 38 & $\begin{array}{l}9-17-85 \\
5-16-86\end{array}$ & $\begin{array}{l}36.4 \\
35.3\end{array}$ \\
\hline Observation & 270 & 250 & 10 & 7.11 & $\begin{array}{l}9-10-85 \\
5-14-86\end{array}$ & $\begin{array}{l}30.00 \\
27.80\end{array}$ \\
\hline Irrigation & 490 & 65 & 8 & 52 & $\begin{array}{l}9-17-85 \\
5-16-86\end{array}$ & $\begin{array}{l}49.2 \\
45.7\end{array}$ \\
\hline Observation & 335 & 220 & 4 & 13.30 & $\begin{array}{r}10-01-85 \\
5-14-86\end{array}$ & $\begin{array}{l}39.87 \\
37.80\end{array}$ \\
\hline Observation & 270 & 110 & 4 & 20 & $\begin{array}{r}10-04-85 \\
5-14-86\end{array}$ & $\begin{array}{l}36.2 \\
34.5\end{array}$ \\
\hline Unknown & 377 & -- & 6 & 44 & $\begin{array}{l}9-13-85 \\
5-16-86\end{array}$ & $\begin{array}{l}48.1 \\
44.9\end{array}$ \\
\hline Irrigation & 411 & 70 & 8 & 35 & $\begin{array}{l}9-12-85 \\
5-15-86\end{array}$ & $\begin{array}{l}44.0 \\
39.2\end{array}$ \\
\hline Irrigation & 428 & 63 & 6 & 21 & $\begin{array}{l}9-12-85 \\
5-15-86\end{array}$ & $\begin{array}{l}35.1 \\
35.5\end{array}$ \\
\hline Irrigation & 329 & 90 & 8 & 50 & $\begin{array}{l}9-13-85 \\
5-15-86\end{array}$ & $\begin{array}{l}50.0 \\
34.9\end{array}$ \\
\hline $\begin{array}{l}\text { Irrigation } \\
\text { Observation }\end{array}$ & $\begin{array}{l}384 \\
340\end{array}$ & $\begin{array}{r}99 \\
300\end{array}$ & $\begin{array}{l}6 \\
6\end{array}$ & $\begin{array}{l}54 \\
60.00\end{array}$ & $\begin{array}{r}9-13-85 \\
10-03-85 \\
5-15-86\end{array}$ & $\begin{array}{l}49.5 \\
50.87 \\
41.64\end{array}$ \\
\hline Unused & 372 & 263 & 8 & 29.33 & $\begin{array}{r}10-02-85 \\
5-16-86\end{array}$ & $\begin{array}{l}48.86 \\
43.36\end{array}$ \\
\hline Irrigation & 311 & 80 & 6 & 42 & $\begin{array}{l}9-12-85 \\
5-15-86\end{array}$ & $\begin{array}{l}43.5 \\
41.8\end{array}$ \\
\hline Unknown & 43.0 & 60 & 4 & 49 & $\begin{array}{l}9-12-85 \\
5-15-86\end{array}$ & $\begin{array}{l}44.6 \\
36.9\end{array}$ \\
\hline Unknown & 320 & 130 & 8 & 59 & $\begin{array}{l}9-13-85 \\
5-15-86\end{array}$ & $\begin{array}{l}47.4 \\
34.2\end{array}$ \\
\hline Unused & 192 & 43 & 3 & 15 & $\begin{array}{l}9-13-85 \\
5-15-86\end{array}$ & $\begin{array}{l}46.0 \\
42.4\end{array}$ \\
\hline Observation & 180 & 140 & 8 & 75.84 & $\begin{array}{l}9-11-85 \\
5-15-86\end{array}$ & $\begin{array}{l}48.37 \\
35.08\end{array}$ \\
\hline $\begin{array}{r}\text { Irrigation } \\
\text { Unknown }\end{array}$ & $\begin{array}{l}430 \\
312\end{array}$ & $\begin{array}{r}144 \\
--\end{array}$ & $\overline{8}$ & $\begin{array}{l}81 \\
94\end{array}$ & $\begin{array}{l}9-12-85 \\
9-16-85 \\
5-12-86\end{array}$ & $\begin{array}{l}37.9 \\
58.6 \\
51.7\end{array}$ \\
\hline
\end{tabular}




\begin{tabular}{|c|c|c|c|}
\hline $\begin{array}{l}\text { Well } \\
\text { No. }\end{array}$ & $\begin{array}{l}\text { Identification } \\
\text { No. }\end{array}$ & County & Owner or name \\
\hline 701 & 272015081392901 & De Soto & Amoco 1 (1eased) \\
\hline 622 & 272038081530701 & Hardee & Limestone Land Company (622) \\
\hline 620 & 272108081582601 & Hardee & Hollingsworth (620) \\
\hline $\begin{array}{l}\mathrm{HA}-44 \\
\mathrm{HA}-21\end{array}$ & $\begin{array}{l}272233081443801 \\
272430081450501\end{array}$ & $\begin{array}{l}\text { Hardee } \\
\text { Hardee }\end{array}$ & $\begin{array}{l}\mathrm{HA}-44 \\
\mathrm{HA}-21\end{array}$ \\
\hline 632 & 272433081591801 & Hardee & Whaley (632) \\
\hline 31 & 272714081545902 & Hardee & ROMP 31 Hawthorn \\
\hline 20 & 272715081401601 & Hardee & Wilbur Robertson \\
\hline 30 & 272728081474702 & Hardee & ROMP 30 Tampa \\
\hline $\mathrm{HA}-89$ & 273108081461301 & Hardee & W. D. Bond (603) \\
\hline $\begin{array}{r}616 \\
2\end{array}$ & $\begin{array}{l}273145081433601 \\
273156081450401\end{array}$ & $\begin{array}{l}\text { Hardee } \\
\text { Hardee }\end{array}$ & $\begin{array}{l}\text { Richardson }(616) \\
\text { Rowe11 Deep }(731-145-1)\end{array}$ \\
\hline $\begin{array}{r}635 \\
U F-3 \\
U F-6\end{array}$ & $\begin{array}{l}273245081500001 \\
273423081582901 \\
273427081513401\end{array}$ & $\begin{array}{l}\text { Hardee } \\
\text { Hardee } \\
\text { Hardee }\end{array}$ & $\begin{array}{l}\text { First Baptist Church } \\
\text { C. F. Industries } \\
\text { C. F. Industries }\end{array}$ \\
\hline $\begin{array}{r}624 \\
A G-1\end{array}$ & $\begin{array}{l}273435081444001 \\
273650081574001\end{array}$ & $\begin{array}{l}\text { Hardee } \\
\text { Hardee }\end{array}$ & $\begin{array}{l}\text { Henderson (624) } \\
\text { Agrico } 1\end{array}$ \\
\hline$A G-2$ & 273709081593501 & Hardee & Agrico 2 \\
\hline 667 & 273714081503401 & Hardee & Paynes Creek Historical Site (667) \\
\hline$A G-3$ & 273820082012101 & Hardee & Agrico 3 \\
\hline $\mathrm{HA}-1$ & 273828081515802 & Hardee & Agri Chem HA-1 \\
\hline$A G-5$ & 273843081573001 & Hardee & Agrico 5 \\
\hline $\begin{array}{l}17 \\
22\end{array}$ & $\begin{array}{l}272012081190201 \\
272652081311501\end{array}$ & $\begin{array}{l}\text { Highlands } \\
\text { Highlands }\end{array}$ & $\begin{array}{l}\text { Jesse Sinkikakis } \\
\text { Prairie Oaks Golf Club }\end{array}$ \\
\hline 11 & 273054081234701 & Highlands & John McCulloch \\
\hline
\end{tabular}




\begin{tabular}{|c|c|c|c|c|c|c|}
\hline $\begin{array}{l}\text { Well } \\
\text { use }\end{array}$ & $\begin{array}{l}\text { Well } \\
\text { depth } \\
\text { (feet) }\end{array}$ & $\begin{array}{l}\text { Casing } \\
\text { depth } \\
\text { (feet) }\end{array}$ & $\begin{array}{l}\text { Casing } \\
\text { diameter } \\
\text { (inches) }\end{array}$ & $\begin{array}{l}\text { Land- } \\
\text { surface } \\
\text { altitude } \\
\text { (feet) }\end{array}$ & Date & $\begin{array}{l}\text { Water- } \\
\text { level } \\
\text { altitude } \\
\text { (feet) }\end{array}$ \\
\hline Irrigation & 284 & 145 & - & 94 & $\begin{array}{l}9-16-85 \\
5-12-86\end{array}$ & $\begin{array}{l}56.1 \\
50.2\end{array}$ \\
\hline Irrigation & 235 & 126 & 4 & 73 & $\begin{array}{l}9-17-85 \\
5-12-86\end{array}$ & $\begin{array}{l}45.8 \\
29.7\end{array}$ \\
\hline Irrigation & 335 & 146 & 6 & 79 & $\begin{array}{l}9-17-85 \\
5-12-86\end{array}$ & $\begin{array}{l}38.6 \\
19.8\end{array}$ \\
\hline $\begin{array}{r}\text { Irrigation } \\
\text { Unused }\end{array}$ & $\begin{array}{l}300 \\
364\end{array}$ & $\begin{array}{l}-- \\
-\end{array}$ & $\begin{array}{l}8 \\
6\end{array}$ & $\begin{array}{l}62 \\
65\end{array}$ & $\begin{array}{l}9-13-85 \\
9-13-85 \\
5-13-86\end{array}$ & $\begin{array}{l}50.2 \\
52.4 \\
45.2\end{array}$ \\
\hline Unused & 159 & $\cdots$ & 4 & 67 & $\begin{array}{l}9-17-85 \\
5-12-86\end{array}$ & $\begin{array}{l}43.1 \\
28.0\end{array}$ \\
\hline Observation & 350 & 130 & 6 & 78.41 & $\begin{array}{l}9-11-85 \\
5-15-86\end{array}$ & $\begin{array}{l}47.71 \\
29.20\end{array}$ \\
\hline Domestic & 343 & 103 & 6 & 75 & $\begin{array}{l}9-16-85 \\
5-13-86\end{array}$ & $\begin{array}{l}63.3 \\
47.7\end{array}$ \\
\hline Observation & 316 & 280 & 8 & 66.73 & $\begin{array}{l}9-11-85 \\
5-15-86\end{array}$ & $\begin{array}{l}51.42 \\
36.97\end{array}$ \\
\hline Unused & 229 & -- & 6 & 92 & $\begin{array}{l}9-13-85 \\
5-13-86\end{array}$ & $\begin{array}{l}60.1 \\
42.3\end{array}$ \\
\hline $\begin{array}{l}\text { Irrigation } \\
\text { Observation }\end{array}$ & $\begin{array}{l}327 \\
267\end{array}$ & $\begin{array}{r}120 \\
39\end{array}$ & $\begin{array}{l}6 \\
6\end{array}$ & $\begin{array}{l}93 \\
98.14\end{array}$ & $\begin{array}{l}9-16-85 \\
9-11-85 \\
5-12-86\end{array}$ & $\begin{array}{l}66.5 \\
60.72 \\
41.46\end{array}$ \\
\hline $\begin{array}{r}\text { Unknown } \\
\text { Observation } \\
\text { Observation }\end{array}$ & $\begin{array}{l}245 \\
375 \\
385\end{array}$ & $\begin{array}{r}130 \\
91 \\
84\end{array}$ & $\begin{array}{r}4 \\
10 \\
8\end{array}$ & $\begin{array}{l}123 \\
117.6 \\
117.5\end{array}$ & $\begin{array}{l}9-16-85 \\
9-12-85 \\
9-12-85 \\
5-14-86\end{array}$ & $\begin{array}{l}56.8 \\
95.8 \\
72.3 \\
61.1\end{array}$ \\
\hline $\begin{array}{l}\text { Irrigation } \\
\text { Observation }\end{array}$ & $\begin{array}{l}293 \\
125\end{array}$ & $\begin{array}{r}105 \\
-.\end{array}$ & $\begin{array}{l}6 \\
6\end{array}$ & $\begin{array}{l}110 \\
113.5\end{array}$ & $\begin{array}{l}9-13-85 \\
9-12-85 \\
5-14-86\end{array}$ & $\begin{array}{l}67.4 \\
91.7 \\
86.5\end{array}$ \\
\hline Observation & 125 & 63 & 4 & 132.5 & $\begin{array}{l}9-10-85 \\
5-14-86\end{array}$ & $\begin{array}{l}107.2 \\
106.0\end{array}$ \\
\hline Public supply & 130 & 119 & - & 62 & $\begin{array}{l}9-12-85 \\
5-13-86\end{array}$ & $\begin{array}{r}60.0 \\
50.0\end{array}$ \\
\hline Observation & 125 & 75 & 4 & 132 & $9-10-85$ & 126.8 \\
\hline Observation & 260 & 195 & 4 & 96.4 & $\begin{array}{l}9-05-85 \\
5-30-86\end{array}$ & $\begin{array}{l}59.6 \\
43.8\end{array}$ \\
\hline Observation & 125 & 59 & 4 & 131.5 & $\begin{array}{l}9-10-85 \\
5-14-86\end{array}$ & $\begin{array}{l}126.7 \\
125.2\end{array}$ \\
\hline Domestic & 190 & $\cdots$ & 3 & 42 & $5-14-86$ & 47.0 \\
\hline Public supply & 239 & 231 & 4 & 116 & $\begin{array}{r}10-24-85 \\
5-14-86\end{array}$ & $\begin{array}{l}77.6 \\
66.3\end{array}$ \\
\hline Domestic & 370 & 160 & 4 & 111 & $\begin{array}{r}10-24-85 \\
5-14-86\end{array}$ & $\begin{array}{l}62.6 \\
82.6\end{array}$ \\
\hline
\end{tabular}




\begin{tabular}{|c|c|c|c|}
\hline $\begin{array}{l}\text { We11 } \\
\text { No. }\end{array}$ & $\begin{array}{c}\text { Identification } \\
\text { No. }\end{array}$ & County & Owner or name \\
\hline 18 & 273353081294201 & Highlands & Floyd DeVane \\
\hline $\begin{array}{l}25 \\
12\end{array}$ & $\begin{array}{l}273704081245501 \\
273725081305301\end{array}$ & $\begin{array}{l}\text { Highlands } \\
\text { Highlands }\end{array}$ & $\begin{array}{l}\text { Robert Richards } \\
\text { Dr. Pena (Dwane Koppa) }\end{array}$ \\
\hline 8 & 273915082191201 & Hillsborough & Saffold \\
\hline 20 & 274044082205101 & Hillsborough & Department of Transportation \\
\hline 88 & 274214082084401 & Hillsborough & Fort Lonesome \\
\hline 422 & 274218082035701 & Hillsborough & Barber \\
\hline$M-2$ & 274400082070901 & Hillsborough & Brewster M-2 Hawthorn \\
\hline 411 & 274440082144201 & Hillsborough & Ruth \\
\hline BHO - 2 & 274446082035401 & Hillsborough & Amax Hawthorn \\
\hline 419 & 274857082195401 & Hi1lsborough & Riverview Hawthorn \\
\hline 226 & 274947082145401 & Hillsborough & Camp Dorothy Thomas 226 \\
\hline 452 & 275156082131501 & Hillsborough & Johnny Todd \\
\hline 455 & 275205082134801 & Hillsborough & Ralph Clark \\
\hline 504 & 275617082223801 & Hillsborough & G. W. Scott \\
\hline 6 & 275917082043601 & Hillsborough & Amax Plant City AEM- 6 \\
\hline 12 & 280006082061601 & Hillsborough & Amax Plant City AEM-12 \\
\hline$L-652$ & 264101081443001 & Lee & Lower Hawthorn \\
\hline L- 2341 & 264517081513201 & Lee & Lower Hawthorn \\
\hline 813 & 271228082072101 & Manatee & $\operatorname{Amax}(513)$ \\
\hline
\end{tabular}




\begin{tabular}{|c|c|c|c|c|c|c|}
\hline $\begin{array}{l}\text { Well } \\
\text { use }\end{array}$ & $\begin{array}{c}\text { Well } \\
\text { depth } \\
\text { (feet) }\end{array}$ & $\begin{array}{l}\text { Casing } \\
\text { depth } \\
\text { (feet) }\end{array}$ & $\begin{array}{l}\text { Casing } \\
\text { diameter } \\
\text { (inches) }\end{array}$ & $\begin{array}{l}\text { Land- } \\
\text { surface } \\
\text { altitude } \\
\text { (feet) }\end{array}$ & Date & $\begin{array}{l}\text { Water- } \\
\text { level } \\
\text { altitude } \\
\text { (feet) }\end{array}$ \\
\hline Irrigation & 340 & 231 & 6 & 132 & $\begin{array}{r}10-25-85 \\
5-14-86\end{array}$ & $\begin{array}{l}91.8 \\
83.6\end{array}$ \\
\hline Domestic & 260 & 140 & 4 & 75 & $5-14-86$ & 73.2 \\
\hline Public supply & 315 & 220 & 4 & 114 & $\begin{array}{r}10-24-85 \\
9-14-86\end{array}$ & $\begin{array}{l}73.3 \\
65.7\end{array}$ \\
\hline Irrigation & 312 & $\cdots$ & 3 & 54 & $\begin{array}{l}9-11-85 \\
5-14-86\end{array}$ & $\begin{array}{l}31.4 \\
15.6\end{array}$ \\
\hline Observation & 155 & 149 & 4 & 60 & $\begin{array}{l}9-11-85 \\
5-14-86\end{array}$ & $\begin{array}{r}19.4 \\
2.2\end{array}$ \\
\hline Domestic & 200 & -. & - & 121 & $\begin{array}{l}9-12-85 \\
5-12-86\end{array}$ & $\begin{array}{l}110.2 \\
108.7\end{array}$ \\
\hline Unknown & 191 & - & - & 134 & $\begin{array}{l}9-12-85 \\
5-12-86\end{array}$ & $\begin{array}{l}117.6 \\
116.7\end{array}$ \\
\hline Observation & 160 & 147 & 4 & 131.12 & $\begin{array}{l}9-30-85 \\
5-31-86\end{array}$ & $\begin{array}{l}106.29 \\
107.02\end{array}$ \\
\hline Domestic & 205 & 95 & - & 105.8 & $\begin{array}{l}9-11-85 \\
5-13-86\end{array}$ & $\begin{array}{l}25.0 \\
10.5\end{array}$ \\
\hline Observation & 194 & 96 & 8 & 112.52 & $\begin{array}{l}9-13-85 \\
5-15-86\end{array}$ & $\begin{array}{l}97.92 \\
95.67\end{array}$ \\
\hline Observation & 161 & 141 & - & 61 & $\begin{array}{l}9-09-85 \\
5-12-86\end{array}$ & $\begin{array}{r}21.0 \\
.1\end{array}$ \\
\hline Recreation & 140 & 111 & 6 & 70.90 & $\begin{array}{l}9-11-85 \\
5-13-86\end{array}$ & $\begin{array}{r}21.54 \\
3.31\end{array}$ \\
\hline Domestic & 215 & 115 & 6 & 63.7 & $\begin{array}{l}9-12-85 \\
5-15-86\end{array}$ & $\begin{array}{r}11.0 \\
8.5\end{array}$ \\
\hline Domestic & 80 & 42 & 4 & - & $\begin{array}{l}9-12-85 \\
5-15-85\end{array}$ & $\begin{array}{r}10.53 \\
8.23\end{array}$ \\
\hline Domestic & 60 & 42 & 2 & 21 & $\begin{array}{l}9-12-85 \\
5-14-86\end{array}$ & $\begin{array}{l}12.5 \\
10.0\end{array}$ \\
\hline Observation & 68 & 58 & 4 & 134.5 & $\begin{array}{l}9-09-85 \\
5-12-86\end{array}$ & $\begin{array}{l}130.3 \\
126.8\end{array}$ \\
\hline Observation & 48 & 38 & 4 & 140 & $\begin{array}{l}9-09-85 \\
5-12-86\end{array}$ & $\begin{array}{l}138.4 \\
135.2\end{array}$ \\
\hline Observation & 598 & 188 & 6 & 68.3 & $\begin{array}{l}9-09-85 \\
5-12-86\end{array}$ & $\begin{array}{l}46.8 \\
42.3\end{array}$ \\
\hline Observation & 585 & 300 & 4 & 22.8 & $\begin{array}{l}9-09-85 \\
5-12-86\end{array}$ & $\begin{array}{l}47.5 \\
45.9\end{array}$ \\
\hline Stock & 106 & $\ldots$ & 2 & 42 & $\begin{array}{l}9-11-85 \\
5-13-86\end{array}$ & $\begin{array}{l}37.3 \\
31.1\end{array}$ \\
\hline
\end{tabular}




\begin{tabular}{|c|c|c|c|}
\hline $\begin{array}{l}\text { We11 } \\
\text { No. }\end{array}$ & $\begin{array}{c}\text { Identification } \\
\text { No. }\end{array}$ & County & Owner or name \\
\hline 20 & 271422082150201 & Manatee & Myakka River State Park \\
\hline 803 & 271622082040101 & Manatee & I.M.C.--Golden Rainbow \\
\hline $\begin{array}{r}23-2 \\
805\end{array}$ & $\begin{array}{l}271906082112402 \\
272051082094601\end{array}$ & $\begin{array}{l}\text { Manatee } \\
\text { Manatee }\end{array}$ & $\begin{array}{l}\text { ROMP 23-2 (N. well) ( } 48 \\
\text { Myakka City Community C }\end{array}$ \\
\hline 807 & 272827082141601 & Manatee & Kibler Lookout Tower \\
\hline 24 & 272830082245801 & Manatee & Bruce Wager \\
\hline $\mathrm{H}-\mathrm{I}$ & 273002082081701 & Manatee & Beker H-1 Hawthorn \\
\hline 25 & 273202082253801 & Manatee & Thomas Metcalf \\
\hline $\begin{array}{r}44 \\
27 \mathrm{~A}\end{array}$ & $\begin{array}{l}273253082072801 \\
273354082352401\end{array}$ & $\begin{array}{l}\text { Manatee } \\
\text { Manatee }\end{array}$ & $\begin{array}{l}\text { Estech Hawthorn } 44 \\
\text { George Steven }\end{array}$ \\
\hline $\begin{array}{l}21 \\
28\end{array}$ & $\begin{array}{l}273428082305701 \\
273506082253701\end{array}$ & $\begin{array}{l}\text { Manatee } \\
\text { Manatee }\end{array}$ & $\begin{array}{l}\text { Marshall Armstrong } \\
\text { Ellen Matheson }\end{array}$ \\
\hline 800 & 273649082123701 & Manatee & W. E. Richter (800) \\
\hline 801 & 273729082091401 & Manatee & Moody (801) \\
\hline 40 & 273851082031502 & Polk & ROMP 40 Hawthorn \\
\hline 29 & 273913081331801 & Polk & Neuman Wegvar \\
\hline 21 & 273923081531901 & Polk & Dotson \\
\hline UF5 & 274009081452202 & Polk & Mobil-UF5 (north we11) \\
\hline UF9 & 274108081474601 & Polk & Mobil-UF9 (north well) \\
\hline UF7 & 274227081460401 & Polk & Mobil-UF7 (one of two) \\
\hline UF1 & 274238081415801 & Polk & Mobil-UF1 (north wel1) \\
\hline
\end{tabular}




\begin{tabular}{|c|c|c|c|c|c|c|}
\hline $\begin{array}{l}\text { We11 } \\
\text { use }\end{array}$ & $\begin{array}{c}\text { We11 } \\
\text { depth } \\
\text { (feet) }\end{array}$ & $\begin{array}{l}\text { Casing } \\
\text { depth } \\
\text { (feet) }\end{array}$ & $\begin{array}{l}\text { Casing } \\
\text { diameter } \\
\text { (inches) }\end{array}$ & $\begin{array}{l}\text { Land- } \\
\text { surface } \\
\text { altitude } \\
\text { (feet) }\end{array}$ & Date & $\begin{array}{c}\text { Water- } \\
\text { level } \\
\text { altitude } \\
\text { (feet) }\end{array}$ \\
\hline Unused & 320 & 56 & 10 & 37 & $\begin{array}{l}9-10-85 \\
5-12-86\end{array}$ & $\begin{array}{l}34.4 \\
25.5\end{array}$ \\
\hline Unused & 100 & -- & - & 62 & $\begin{array}{l}9-11-85 \\
5-13-86\end{array}$ & $\begin{array}{l}40.0 \\
28.7\end{array}$ \\
\hline Observation & 374 & 304 & 6 & 62.5 & $9-11-85$ & 30.0 \\
\hline Public supply & - & - & - & 43 & $\begin{array}{l}9-11-85 \\
5-13-86\end{array}$ & $\begin{array}{l}33.6 \\
24.4\end{array}$ \\
\hline Domestic & 140 & $\cdots$ & 4 & 97 & $\begin{array}{l}9-11-85 \\
5-13-86\end{array}$ & $\begin{array}{l}24.1 \\
-4.1\end{array}$ \\
\hline Domestic & 264 & 50 & 4 & 34 & $\begin{array}{r}10-30-85 \\
5-14-86\end{array}$ & $\begin{array}{r}17.4 \\
8.8\end{array}$ \\
\hline Observation & 200 & 130 & 4 & 101 & $\begin{array}{l}9-15-85 \\
5-13-86\end{array}$ & $\begin{array}{l}46.1 \\
40.9\end{array}$ \\
\hline Irrigation & 255 & 126 & 5 & 18 & $\begin{array}{r}10-28-85 \\
5-14-86\end{array}$ & $\begin{array}{r}-1.0 \\
-14.0\end{array}$ \\
\hline Observation & 250 & 145 & - & 120 & $9-09-85$ & 104.5 \\
\hline Unknown & 110 & 50 & 3 & 5 & $5-19-86$ & 6.0 \\
\hline Domestic & 185 & 113 & 4 & 23 & $5-14-86$ & 4.1 \\
\hline Domestic & 180 & 106 & 5 & 42 & $\begin{array}{r}10-28-85 \\
5-14-86\end{array}$ & $\begin{array}{r}11.8 \\
.5\end{array}$ \\
\hline Domestic & 350 & 80 & 6 & 108 & $\begin{array}{l}9-11-85 \\
5-13-86\end{array}$ & $\begin{array}{l}96.3 \\
94.3\end{array}$ \\
\hline Unknown & 280 & 168 & - & 125 & $\begin{array}{l}9-11-85 \\
5-13-86\end{array}$ & $\begin{array}{l}93.6 \\
95.1\end{array}$ \\
\hline Observation & 180 & 76 & 12 & 137.94 & $\begin{array}{l}9-11-85 \\
5-14-86\end{array}$ & $\begin{array}{l}127.04 \\
126.30\end{array}$ \\
\hline Irrigation & 240 & 170 & 6 & 131 & $\begin{array}{l}9-09-85 \\
5-14-86\end{array}$ & $\begin{array}{l}83.5 \\
68.1\end{array}$ \\
\hline Domestic & 220 & 147 & 4 & 118 & $\begin{array}{l}9-10-85 \\
5-13-86\end{array}$ & $\begin{array}{l}63.8 \\
50.3\end{array}$ \\
\hline Unknown & 217 & 192 & - & 131 & $\begin{array}{l}9-09-85 \\
5-12-86\end{array}$ & $\begin{array}{l}74.0 \\
62.1\end{array}$ \\
\hline Unknown & 235 & 202 & - & 102 & $\begin{array}{l}9-09-85 \\
5-12-86\end{array}$ & $\begin{array}{l}65.1 \\
52.0\end{array}$ \\
\hline Unknown & 215 & 202 & - & 122.5 & $\begin{array}{l}9-09-85 \\
5-12-86\end{array}$ & $\begin{array}{l}67.2 \\
60.1\end{array}$ \\
\hline Unknown & 243 & 221 & - & 163 & $\begin{array}{l}9-09-85 \\
5-14-86\end{array}$ & $\begin{array}{l}83.6 \\
67.6\end{array}$ \\
\hline
\end{tabular}




\begin{tabular}{|c|c|c|c|}
\hline $\begin{array}{l}\text { We11 } \\
\text { No. }\end{array}$ & $\begin{array}{c}\text { Identification } \\
\text { No. }\end{array}$ & County & Owner or name \\
\hline 81 & 274358081540401 & Polk & Pierce Tower $(743-154-1)$ \\
\hline 36 & 274440081314801 & Polk & Coley well \\
\hline 45 & 274547081470901 & Polk & ROMP 45 Hawthorn \\
\hline 119 & 274722081590001 & Polk & Bennet 119 \\
\hline 140 & 274847081414501 & Polk & C. D. Cloninger \\
\hline 8 & 275040081493001 & Polk & I.M.C. 22A Hawthorn \\
\hline $\begin{array}{r}164 \\
41\end{array}$ & $\begin{array}{l}275059081562201 \\
275129082010401\end{array}$ & $\begin{array}{l}\text { Polk } \\
\text { Polk }\end{array}$ & $\begin{array}{l}\text { Weigh Station (164) } \\
751-201-1\end{array}$ \\
\hline 42 & 275158081494601 & Polk & Cochran (I.M.C.) \\
\hline 54 & 275301081495701 & Polk & L. B. Barnes \\
\hline 59 & 275314081514202 & Polk & ROMP 59 Hawthorn we11 \\
\hline 57 & 275411081372002 & Polk & ROMP 57-2 Hawthorn \\
\hline 64 & 275523081502601 & Po1k & $755-150-3$ (Stuart) \\
\hline 1PN & 280437081410207 & Polk & 1PN near Winter Haven \\
\hline 90 & 280550081542501 & Polk & Francis Lee \\
\hline 10 & 280715081543501 & Polk & $807-154-433$ \\
\hline 1 & 265653082190301 & Sarasota & Englewood Ro Test 1 \\
\hline 2 & 265710082205101 & Sarasota & Englewood RO Test 2 \\
\hline $\begin{array}{r}3 \\
18\end{array}$ & $\begin{array}{l}270106082214101 \\
270714082155201\end{array}$ & $\begin{array}{l}\text { Sarasota } \\
\text { Sarasota }\end{array}$ & $\begin{array}{l}\text { Englewood deep zone no. } 3 \\
\text { Blackburn Ranch Test } 18\end{array}$ \\
\hline
\end{tabular}




\begin{tabular}{|c|c|c|c|c|c|c|}
\hline $\begin{array}{l}\text { We11 } \\
\text { use }\end{array}$ & $\begin{array}{c}\text { We11 } \\
\text { depth } \\
\text { (feet) }\end{array}$ & $\begin{array}{l}\text { Casing } \\
\text { depth } \\
\text { (feet) }\end{array}$ & $\begin{array}{l}\text { Casing } \\
\text { diameter } \\
\text { (inches) }\end{array}$ & $\begin{array}{l}\text { Land- } \\
\text { surface } \\
\text { altitude } \\
\text { (feet) }\end{array}$ & Date & $\begin{array}{l}\text { Water- } \\
\text { leve1 } \\
\text { altitude } \\
\text { (feet) }\end{array}$ \\
\hline Domestic & 201 & 110 & 4 & 140 & $\begin{array}{l}9-10-85 \\
5-12-86\end{array}$ & $\begin{array}{l}128.9 \\
124.1\end{array}$ \\
\hline Observation & 319 & 208 & 6 & 97.5 & $\begin{array}{l}9-09-85 \\
5-13-86\end{array}$ & $\begin{array}{l}85.0 \\
68.4\end{array}$ \\
\hline Observation & 192 & 110 & 4 & 121.58 & $\begin{array}{l}9-11-85 \\
5-14-86\end{array}$ & $\begin{array}{l}68.34 \\
55.67\end{array}$ \\
\hline Unknown & 110 & $\ldots$ & 4 & 130 & $\begin{array}{l}9-10-85 \\
5-12-86\end{array}$ & $\begin{array}{l}96.8 \\
90.6\end{array}$ \\
\hline Unknown & - & - & - & 152 & $\begin{array}{l}9-09-85 \\
5-12-86\end{array}$ & $\begin{array}{l}125.8 \\
120.1\end{array}$ \\
\hline Observation & 227 & 68 & 8 & 122.53 & $\begin{array}{l}9-09-85 \\
5-13-86\end{array}$ & $\begin{array}{ll}77,2 \\
6,6 & 51\end{array}$ \\
\hline $\begin{array}{l}\text { Unknown } \\
\text { Domestic }\end{array}$ & $\begin{array}{r}167 \\
80\end{array}$ & $\begin{array}{l}92 \\
60\end{array}$ & $\begin{array}{l}4 \\
4\end{array}$ & $\begin{array}{l}151 \\
125\end{array}$ & $\begin{array}{l}5-12-86 \\
9-10-85 \\
5-12-86\end{array}$ & $\begin{array}{r}.1 .5 \\
108.0 \\
102.8\end{array}$ \\
\hline Irrigation & 125 & 65 & 4 & 133.67 & $\begin{array}{l}9-09-85 \\
5-13-86\end{array}$ & $\begin{array}{l}79.85 \\
71.83\end{array}$ \\
\hline Irrigation & 120 & 60 & 4 & 126.05 & $\begin{array}{l}9-11-85 \\
5-15-86\end{array}$ & $\begin{array}{l}73.56 \\
68.40\end{array}$ \\
\hline Observation & 142 & 122 & 6 & 117.84 & $\begin{array}{l}9-11-85 \\
5-14-86\end{array}$ & $\begin{array}{ll}7 & 96 \\
\because & 1\end{array}$ \\
\hline Observation & 140 & 95 & 7 & 128.10 & $\begin{array}{l}9-11-85 \\
5-12-86\end{array}$ & $\begin{array}{l}1 \\
1:\end{array}$ \\
\hline Unused & 73 & 57 & 2 & 111 & $\begin{array}{l}9-09-85 \\
5-13-86\end{array}$ & $\begin{array}{l}8,3 \\
65.5\end{array}$ \\
\hline Unknown & 155 & 132 & - & 133 & $\begin{array}{l}9-09-85 \\
5-14-86\end{array}$ & $\begin{array}{l}12 \% \cdot 4 \\
11 \% .3\end{array}$ \\
\hline Unused & 97 & 60 & 2 & 137.4 & $\begin{array}{l}9-09-85 \\
5-12-86\end{array}$ & $\begin{array}{l}12=4 \\
127.4\end{array}$ \\
\hline Observation & 55 & 31 & 3 & 136.2 & $\begin{array}{l}9-06-85 \\
5-14-86\end{array}$ & $\begin{array}{l}134.8 \\
133.0\end{array}$ \\
\hline Unused & 320 & 175 & 4 & 7 & $\begin{array}{l}9-10-85 \\
5-14-86\end{array}$ & $\begin{array}{l}15.6 \\
14.2\end{array}$ \\
\hline Unused & 310 & 152 & 4 & 10 & $\begin{array}{l}9-10-85 \\
5-14-86\end{array}$ & $\begin{array}{r}11.7 \\
9.0\end{array}$ \\
\hline $\begin{array}{l}\text { Observation } \\
\text { Unknown }\end{array}$ & $\begin{array}{l}135 \\
351\end{array}$ & $\begin{array}{l}109 \\
282\end{array}$ & $\begin{array}{l}4 \\
4\end{array}$ & $\begin{array}{l}14.36 \\
25\end{array}$ & $\begin{array}{l}9-11-85 \\
9-10-85 \\
5-13-86\end{array}$ & $\begin{array}{l}13.45 \\
39.6 \\
3.5\end{array}$ \\
\hline
\end{tabular}




\begin{tabular}{|c|c|c|c|}
\hline $\begin{array}{l}\text { Well } \\
\text { No. }\end{array}$ & $\begin{array}{c}\text { Identification } \\
\text { No. }\end{array}$ & County & Owner or name \\
\hline TR5 - 1 & 270808082270503 & Sarasota & ROMP TR5-1 Hawthorn \\
\hline 70 & 270822082231101 & Sarasota & Henry Ranch 1 \\
\hline TR5 - 2 & 270919082234203 & Sarasota & ROMP TR5-2 lower Hawthorn \\
\hline $\begin{array}{r}\text { TR5 - } 2 \\
82\end{array}$ & $\begin{array}{l}270919082234204 \\
270931082252901\end{array}$ & $\begin{array}{l}\text { Sarasota } \\
\text { Sarasota }\end{array}$ & $\begin{array}{l}\text { ROMP TR5-2 Floridan } \\
\text { Ewing Ranch (Holland) }\end{array}$ \\
\hline $19 \mathrm{E}$ & 271021082151602 & Sarasota & ROMP 29 East (intermediate aquifer) \\
\hline 93 & 271118082082401 & Sarasota & Mabry Carlton 16 \\
\hline 9 & 271118082285301 & Sarasota & Osprey 9 \\
\hline 110 & 271220082295201 & Sarasota & Sarasota County Historical Society \\
\hline 25 & 271522082165801 & Sarasota & 01d Palmer We11 \\
\hline TR6 - 1 & 271601082330501 & Sarasota & ROMP TR6-1 Hawthorn \\
\hline 28 & 272045082325201 & Sarasota & Florida Power and Light \\
\hline 11 & 272049082324401 & Sarasota & City of Sarasota, 11th Street \\
\hline 27 & 272133082324701 & Sarasota & City of Sarasota, 27 th Street \\
\hline
\end{tabular}




\begin{tabular}{|c|c|c|c|c|c|c|}
\hline $\begin{array}{l}\text { We11 } \\
\text { use }\end{array}$ & $\begin{array}{c}\text { We11 } \\
\text { depth } \\
\text { (feet) }\end{array}$ & $\begin{array}{l}\text { Casing } \\
\text { depth } \\
\text { (feet) }\end{array}$ & $\begin{array}{c}\text { Casing } \\
\text { diameter } \\
\text { (inches) }\end{array}$ & $\begin{array}{l}\text { Land- } \\
\text { surface } \\
\text { altitude } \\
\text { (feet) }\end{array}$ & Date & $\begin{array}{l}\text { Water- } \\
\text { leve1 } \\
\text { altitude } \\
\text { (feet) }\end{array}$ \\
\hline Observation & 289 & 275 & 4 & 11.62 & $\begin{array}{l}9-11-85 \\
5-13-86\end{array}$ & $\begin{array}{l}14.72 \\
10.73\end{array}$ \\
\hline Unknown & 286 & 40 & 8 & 15 & $\begin{array}{l}9-10-85 \\
5-13-86\end{array}$ & $\begin{array}{l}17.6 \\
17.1\end{array}$ \\
\hline Observation & 265 & 245 & 4 & 15 & $\begin{array}{l}9-10-85 \\
5-13-86\end{array}$ & $\begin{array}{l}27.9 \\
22.3\end{array}$ \\
\hline $\begin{array}{l}\text { Observation } \\
\text { Irrigation }\end{array}$ & $\begin{array}{l}400 \\
256\end{array}$ & $\begin{array}{r}360 \\
44\end{array}$ & $\begin{array}{l}2 \\
6\end{array}$ & $\begin{array}{l}15 \\
15\end{array}$ & $\begin{array}{l}5-13-86 \\
9-10-85\end{array}$ & $\begin{array}{l}21.9 \\
21.5\end{array}$ \\
\hline Observation & 121 & 80 & 18 & 31 & $\begin{array}{l}9-11-85 \\
5-13-86\end{array}$ & $\begin{array}{l}31.7 \\
28.1\end{array}$ \\
\hline Irrigation & 301 & 62 & 8 & 37 & $\begin{array}{l}9-10-85 \\
5-13-86\end{array}$ & $\begin{array}{l}35.0 \\
29.8\end{array}$ \\
\hline Observation & 255 & 157 & 4 & 14.37 & $\begin{array}{l}9-11-85 \\
5-13-86\end{array}$ & $\begin{array}{l}13.77 \\
10.13\end{array}$ \\
\hline Unknown & 224 & 41 & 4 & 10 & $\begin{array}{l}9-10-85 \\
5-13-86\end{array}$ & $\begin{array}{l}13.4 \\
10.1\end{array}$ \\
\hline Unused & 360 & 72 & 4 & 15 & $\begin{array}{l}9-10-85 \\
5-12-86\end{array}$ & $\begin{array}{l}17.5 \\
10.4\end{array}$ \\
\hline Observation & 315 & 300 & 6 & 5 & $\begin{array}{r}10-04-85 \\
5-15-86\end{array}$ & $\begin{array}{l}9.1 \\
5.3\end{array}$ \\
\hline Unused & 358 & 108 & 4 & 10 & $\begin{array}{l}9-09-85 \\
5-15-86\end{array}$ & $\begin{array}{r}11.6 \\
7.1\end{array}$ \\
\hline Observation & 479 & 43 & 6 & 8.73 & $\begin{array}{l}9-11-85 \\
5-15-86\end{array}$ & $\begin{array}{r}14.20 \\
5.61\end{array}$ \\
\hline Observation & 343 & 45 & 12 & 6.84 & $\begin{array}{l}9-11-85 \\
5-13-86\end{array}$ & $\begin{array}{r}13.86 \\
2.39\end{array}$ \\
\hline
\end{tabular}


APPENDIX B: Index of Geophysical

[All wells were logged by the U.S. Geological Survey or by the Southwest Survey Southwest Florida Subdistrict Office in Tampa. Type of other

We11 number

Local name

County

Date

264611081555401 264717081363701

264809081564901

264840081443101

264899081363401

264918082011801 264923082011701 264923082013701 265017082153701 265044082002701

265050082004401 265052082002101 265057082002701 265108082171801 265124081433601

265124081453701 265124082012401 265127081532501 265128081429401 265131081572101

265158082171701 265158082171702

265202082121202

265202082171701

265202082171702

265204082005501 265215082005501 265218082012901 265218082140301 265233081201301

265247082180901 265257081444101 265258082011001 265313081442601 265316081433601

265318081441501 265321081442601 265326081433901 265342082005501
U.S. Geological Survey

Babcock

$20-410$

Babcock

Babcock

Hot Springs

C-107

Hot Springs

U.S. Geological Survey

C- 103

C- 102

So Sweet Groves

C- 104

Rotunda Inc.

Babcock

U.S. Geological Survey

Horc \#1

U.S. Geological Survey

Babcock

Cecil Webb Wildlife Preserve

Rotunda Inc.

Rotunda Inc.

Rotunda Inc.

Rotunda Inc.

Rotunda Inc.

C -99

C- 96

PGI \#1

Rotunda Inc.

Gasparilla Pines

Babcock

20-45

Babcock

Babcock

Babcock

Babcock

Babcock

20-682
Charlotte

Charlotte

Charlotte

Charlotte

Charlotte

Charlotte

Charlotte

Charlotte

Charlotte

Charlotte

Charlotte

Charlotte

Charlotte

Charlotte

Charlotte

Charlotte

Charlotte

Charlotte

Charlotte

Charlotte

Charlotte

Charlotte

Charlotte

Charlotte

Charlotte

Charlotte

Charlotte

Charlotte

Charlotte

Charlotte

Charlotte

Charlotte

Charlotte

Charlotte

Charlotte

Charlotte

Charlotte

Charlotte

Charlotte
$7-68$

$--$

$12-83$

$7-70$

$8-69$

$11-66$

$11-66$

$2-63$

$11-66$

9-65

9-65

$9-63$

$9-65$

$11-71$

7-68

$8-68$

$7-69$

$8-68$

$9-70$

6-68

$3-72$

$6-72$

$5-72$

$3-72$

5- 72

$7-70$

$7-70$

$3-80$

$2-72$

$10-69$

$2-72$

$8-68$

$6-80$

4- 67

4-69

4- 69

4-69

4-67

4- 85 
Logs in Southwest Florida

Florida Water Management District and are on file in the U.S. Geological log: f, fluid velocity; $g$, gamma-gamma density; $n$, neutron; $s$, sonic]

\begin{tabular}{|c|c|c|c|c|c|c|}
\hline \multicolumn{7}{|c|}{$\begin{array}{l}\text { Type of } 10 g \text { and depth logged, } \\
\text { in feet below land-surface datum }\end{array}$} \\
\hline Electric & $\begin{array}{l}\text { Gamma- } \\
\text { ray }\end{array}$ & Caliper & $\begin{array}{c}\text { Fluid } \\
\text { conductivity }\end{array}$ & $\begin{array}{c}\text { Tempera- } \\
\text { ture }\end{array}$ & $\begin{array}{l}\text { Flow } \\
\text { meter }\end{array}$ & Other \\
\hline 49 & 190 & 49 & - - & - - & $\ldots$ & - - \\
\hline 210 & 210 & - & - & -- & - & -- \\
\hline 667 & 667 & 667 & 667 & 667 & - - & -- \\
\hline 542 & 542 & - - & - - & - & - - & -- \\
\hline-- & -- & -- & -- & -- & -- & -- \\
\hline 516 & $\ldots$ & - & - & -- & $\ldots$ & - \\
\hline 265 & - - & 265 & - - & - - & - - & - - \\
\hline 1,575 & 1,500 & - - & - - & - - & - - & - - \\
\hline 408 & 408 & -- & $\ldots$ & - & - - & - - \\
\hline 1,116 & 760 & -- & - & - & - & -- \\
\hline 1,160 & 1,160 & - & $\ldots$ & - & -- & -- \\
\hline 992 & - - & - & - & - & - - & - \\
\hline 1,155 & - & - & - & - & - - & - - \\
\hline 246 & 312 & 242 & - & - & - - & -- \\
\hline - - & 114 & - - & -- & -- & -- & -- \\
\hline 197 & - & - & - & - & - & -- \\
\hline 1,454 & 1,454 & 1,454 & 1,454 & $\ldots$ & $\ldots$ & - \\
\hline 54 & 264 & 48 & 264 & 264 & - & -- \\
\hline 450 & 450 & 450 & - & - & - - & - - \\
\hline 384 & 564 & 384 & 564 & - & - & - \\
\hline 66 & 120 & 65 & $\ldots$ & - & - & - - \\
\hline 25 & 144 & 23 & - & - & - & - \\
\hline 23 & 140 & 21 & -- & - & - & - - \\
\hline 78 & 136 & 78 & - & - & - - & $\ldots$ \\
\hline 23 & 140 & 21 & - & - & - & - \\
\hline 894 & 894 & 894 & 894 & - & - & $f$ \\
\hline 460 & - - & 460 & - & - & - - & $f$ \\
\hline 182 & 182 & 182 & 183 & 182 & - & - \\
\hline 87 & 162 & 87 & -- & - - & - - & - - \\
\hline - - & 489 & -- & -- & -- & - - & -- \\
\hline 54 & 390 & 54 & - - & - - & - & $\ldots$ \\
\hline 174 & 284 & 174 & 282 & 282 & - - & - - \\
\hline - - & - - & 3 & - - & - - & - & _- \\
\hline 272 & 272 & - & - & - - & - & - - \\
\hline - & 908 & 908 & - - & -- & - - & $f$ \\
\hline 221 & 221 & - & - & - - & - & - - \\
\hline 459 & 459 & 439 & 459 & - - & - & - - \\
\hline 188 & 188 & - & - & - & - - & - - \\
\hline - - & - - & 566 & -- & -- & - - & -- \\
\hline
\end{tabular}


265343081292601

265355081580701

265404082011901

265456082162201

265504082000601

265531082194801

265531082194801

265549082125901

265549082125901

265555081590501

265557082162201

265613082174501

265615081543501

265622082121601

265638082130701

265641081590301

265645082194701

265646081554501

265646081584601

265648081514701

265649081565101

265652082185801

265719081464801

265739081591401

265749081414701

265759082040101

265802081544401

265828081414601

265830081565501

265833081530201

265835081565501

265836081565101

265837081561101

265838081530701

265842081414801

265843081424601

265851081591301

265853081414801

265855081545901

265902082032801
$20-1006$

$20-462$

$20-64$

Rotunda Inc.

U.S. Geological Survey

ROMP TR3 - 3

ROMP TR3-3

Nat Wolfe

20-94

Golden Groves

U.S. Geological Survey

General Development Corporation

Florida State Game and Fresh Fish

General Development Corporation

TR3 - 1

Swiss Groves

TW \#3 Aldersgate Development

U.S. Geological Survey

Swiss Groves

E. J. Hall

M. H. Davis

Englewood Water District

$20-650$

$20-82$

Tropical River Groves

Paul Smith

Lary Zehner

Tropical River Groves

$\mathrm{Da}$ Costa

J. B. Washington

20-525 Peter Ray \#2

20-528 Peter Ray \#1

Shell Creek 20-981-0093

$\mathrm{J}$. B. Washington \#2

Tropical River Groves

B $-1-W$

$20-68$

B -7

$20-80$

Suncoast Peach Company
Charlotte

$6-80$

Charlotte

Charlotte

Charlotte

Charlotte

Charlotte

Charlotte

Charlotte

Charlotte

Charlotte

Charlotte

Charlotte

Charlotte

Charlotte

Charlotte

Charlotte

Charlotte

Charlotte

Charlotte

Charlotte

Charlotte

Charlotte

Charlotte

Charlotte

Charlotte

Charlotte

Charlotte

Charlotte

Charlotte

Charlotte

Charlotte

Charlotte

Charlotte

Charlotte

Charlotte

Charlotte

Charlotte

Charlotte

Charlotte

Charlotte
4-85

$2-68$

$7-72$

$8-68$

$6-86$

$6-86$

$2-68$

$6-79$

6- 68

10-66

4- 72

4- 68

2-82

3- 81

4- 72

7-72

8-86

$7-79$

7-68

$7-68$

$2-76$

$5-85$

7-80

$1-68$

$11-65$

$10-68$

$1-76$

4-85

3- 62

4- 85

4-85

$7-75$

3- 62

2-68

1-69

$6-78$

1- 69

$6-79$

9-67 


\begin{tabular}{|c|c|c|c|c|c|c|}
\hline \multicolumn{7}{|c|}{$\begin{array}{l}\text { Type of log and depth logged, } \\
\text { in feet below land-surface datum }\end{array}$} \\
\hline Electric & $\begin{array}{l}\text { Gamma- } \\
\text { ray }\end{array}$ & Caliper & $\begin{array}{c}\text { Fluid } \\
\text { conductivity }\end{array}$ & $\begin{array}{c}\text { Tempera- } \\
\text { ture }\end{array}$ & $\begin{array}{l}\text { Flow } \\
\text { meter }\end{array}$ & Other \\
\hline 524 & 524 & 524 & - & 524 & - & - \\
\hline -. & - & 386 & - & 386 & - & - \\
\hline 274 & - & - & -- & -- & -- & $\cdots$ \\
\hline 88 & 151 & 87 & - & - & -- & - - \\
\hline 29 & 152 & 29 & -- & - & -- & - \\
\hline$\ldots$ & - & -- & - & 1,540 & -. & - \\
\hline- & - & $\ldots$ & 540 & - & - & -. \\
\hline 255 & 291 & $\cdots$ & -- & - & -- & $\cdots$ \\
\hline - & 300 & - & - - & 300 & - & - \\
\hline -. & 276 & - & - & - - & - - & - \\
\hline 186 & 298 & - & - & - & - & - - \\
\hline 272 & 272 & 272 & - & - & 272 & -- \\
\hline 521 & 637 & 521 & - & -- & - & - \\
\hline 992 & - & 996 & 994 & 984 & - & - \\
\hline 608 & 608 & 608 & 603 & 608 & -- & -- \\
\hline 922 & 922 & - & - & 922 & $\ldots$ & - \\
\hline - & 141 & - & - & 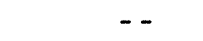 & $\cdots$ & - \\
\hline 83 & 279 & 83 & 279 & -- & -- & -- \\
\hline- & 915 & 915 & 915 & 918 & - & -. \\
\hline 800 & 956 & 800 & 956 & 956 & -- & -- \\
\hline 98 & 424 & 98 & 424 & 424 & - & - \\
\hline - & - & 912 & - & - & - & - \\
\hline 890 & 890 & 890 & 890 & 890 & - & - \\
\hline 792 & 792 & 792 & - & 792 & - & - \\
\hline 518 & 518 & 585 & - & - & -- & -- \\
\hline 403 & 120 & - & - & $\ldots$ & - & $\ldots$ \\
\hline 453 & - & - & - & - & - & - \\
\hline 406 & - & 408 & - & - & $\cdots$ & $\cdots$ \\
\hline - & - & 928 & 928 & 928 & - & - \\
\hline 653 & - & -- & -- & -- & - & - \\
\hline -. & $\ldots$ & 566 & - & 612 & -. & - \\
\hline - & - & 612 & - & 612 & -- & - \\
\hline- & 330 & 330 & 330 & 330 & - & - \\
\hline 497 & 497 & - & - - & -- & - - & - \\
\hline 1,256 & 1,256 & -- & -- & -- & -- & -- \\
\hline 510 & 510 & 510 & 510 & - & - - & $\ldots$ \\
\hline-- & 400 & 400 & - - & 400 & - - & -. \\
\hline 536 & - & - & - - & - & -- & - \\
\hline 630 & 560 & 630 & - & - & -- & - - \\
\hline 586 & 586 & 586 & 586 & - & 586 & - \\
\hline
\end{tabular}


265906081414701 265910081454201 265916082290301 265920082045601 265932081424701

265941081561401 265947081424701 265959081393601 270002082090801 270005082074401

270013081425101 270014081425001 270028082081801 270030082071802 270043082084601

270043082085701 270044082084701 270100082073301 270102081533101 270105081534001

270106082073501 270112082005201 270120081533801 270131082080401 270133082034601

270134082075101 270136081533601 270136082010201 270137082074201 270141082071701

270152082002801 270152082002801 270152082002801 270152082002802 270152082002802

270152082002803 270152082002803 270152082002804 270152082092201 270154082102501
Tropical River Groves

Nat Wolfe

Buffam

Port Charlotte Golf Course

Tropical River Groves

U.S. Geological Survey

Tropical River Groves

Tropical River Groves

General Development Corporation 20-89

$20-1015$

$20-1016$

General Development Corporation Restlawn Memorial Gardens

General Development Corporation

General Development Corporation General Development Corporation General Development Corporation Ryals \#4

Ryals \#1

General Development Corporation P.G.I. \#2

Ryals \#3

General Development Corporation U.S. Geological Survey

General Development Corporation Ryals \#5

P.G.I. \#3

General Development Corporation General Development Corporation

ROMP 10 U.S. Geological Survey SWFWMD ROMP 10

SWFWMD ROMP 10

SWFWMD

SWFWMD ROMP 10

SWFWMD

SWFWMD ROMP 10

U.S. Geological Survey

General Development Corporation

General Development Corporation
Charlotte

$1-69$

Charlotte

Charlotte

Charlotte

Charlotte

Charlotte

Charlotte

Charlotte

Charlotte

Charlotte

Charlotte

Charlotte

Charlotte

Charlotte

Charlotte

Charlotte

Charlotte

Charlotte

Charlotte

Charlotte

Charlotte

Charlotte

Charlotte

Charlotte

Charlotte

Charlotte

Charlotte

Charlotte

Charlotte

Charlotte

Charlotte

Charlotte

Charlotte

Charlotte

Charlotte

Charlotte

Charlotte

Charlotte

Charlotte

Charlotte
$10-68$

$7-67$

10-66

2-69

$7-68$

10-67

$10-67$

$3-60$

$3-79$

11-84

$11-84$

$12-68$

4-68

2-68

$12-68$

$3-60$

3- 60

10-68

$11-68$

$9-68$

4- 80

$11-68$

3- 60

2-66

3- 60

10-68

4-80

$9-68$

$9-68$

7-75

7-75

3-75

$7-75$

$7-75$

7-75

$7-75$

7-75

3-60

3- 60 


\begin{tabular}{|c|c|c|c|c|c|c|}
\hline \multicolumn{7}{|c|}{$\begin{array}{l}\text { Type of } \log \text { and depth logged, } \\
\text { in feet below land-surface datum }\end{array}$} \\
\hline Electric & $\begin{array}{l}\text { Gamma- } \\
\text { ray }\end{array}$ & Caliper & $\begin{array}{c}\text { Fluid } \\
\text { conductivity }\end{array}$ & $\begin{array}{c}\text { Tempera- } \\
\text { ture }\end{array}$ & $\begin{array}{l}\text { Flow } \\
\text { meter }\end{array}$ & Other \\
\hline- & 483 & - & - & $\cdots$ & $\ldots$ & - \\
\hline 508 & 608 & 508 & $\ldots$ & - & -- & - \\
\hline 173 & - - & - - & 173 & - - & - & - \\
\hline 28 & 152 & - & - & - & - & - \\
\hline 365 & 365 & 365 & -- & -- & -- & -- \\
\hline 31 & 360 & 31 & 360 & 360 & - & $\ldots$ \\
\hline 414 & 474 & 414 & -. & -. & - & - - \\
\hline 354 & 418 & 418 & - & - & $\ldots$ & - \\
\hline 176 & - & - - & - - & - - & - - & $\ldots$ \\
\hline-- & 266 & 266 & -- & 264 & $\cdots$ & - \\
\hline- & $\ldots$ & 129 & 129 & $\ldots$ & $\ldots$ & $\ldots$ \\
\hline 450 & 450 & 450 & 450 & 450 & 450 & - \\
\hline 227 & 227 & 227 & $\ldots$ & - & -- & $f$ \\
\hline 281 & 425 & - & - & - & - & $\cdots$ \\
\hline 184 & 256 & $\cdots$ & - & - & - & - \\
\hline 269 & 269 & 269 & - - & - & -- & - \\
\hline 412 & - - & - & - & - & - & $\ldots$ \\
\hline 267 & $\ldots$ & - - & - & - & $\ldots$ & - \\
\hline 596 & $\cdots$ & $\cdots$ & - & - & - & $f$ \\
\hline 392 & 392 & 392 & - & - & - & - \\
\hline 288 & - & $=$ & - & $\cdots$ & 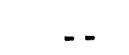 & - \\
\hline 628 & 628 & 625 & - & 625 & - & $\ldots$ \\
\hline 392 & 392 & 392 & - & $\ldots$ & - & - \\
\hline 287 & $\cdots$ & -- & - & $\ldots$ & - & $\cdots$ \\
\hline 344 & - & 186 & -- & - & -- & -- \\
\hline 473 & 473 & - & - & $\ldots$ & $\cdots$ & - \\
\hline 612 & - & - & $\ldots$ & $\ldots$ & $\ldots$ & $\ldots$ \\
\hline 417 & 418 & 417 & 418 & 418 & $\ldots$ & $\ldots$ \\
\hline 456 & 456 & 546 & - & - & - & - \\
\hline 453 & 453 & - & - & - & - & $\cdots$ \\
\hline 9 & - & - & - & - & - & - \\
\hline 46 & $\ldots$ & 56 & - & - & -. & -. \\
\hline 831 & - & 860 & - & - & - & -. \\
\hline 284 & - & 275 & - & - & -. & -. \\
\hline 284 & - & 275 & - - & - & -. & .. \\
\hline 173 & - & 175 & $\ldots$ & - & - & -. \\
\hline 173 & -- & 175 & -- & - & - & - \\
\hline 9 & -- & - & - & $\cdots$ & - & $\ldots$ \\
\hline 502 & - & - & - & - & - & - \\
\hline 212 & - & - - & - & -. & - - & - \\
\hline
\end{tabular}


270157082071001 General Development Corporation 270159082033101 General Development Corporation 275557081584901 275558081584901 270225081415701

270234081575801 270239081574601 270246081424301 270306081420001 270312082024201

270320081491201 270330081542901 270333081473301 270333081484701 270345082002401

270345082012901 270347081510201 270347081573201 270356081484101 270359081464401

270412081474901 270413081585801 270414081584701 270417081575601 270419081585901

270530082000601 270554082003601 270555082003901 270609082010101 270611082000401

270624081494301 270807082002801 270811081481101 270814081481101 270826082004101

270826082004101 270831081583401 270953081570601 270958081554001 270958081581201

\section{0-409}

$20-1014$

University of Texas

R. W. Banks

Arthur

University Board of Regents

V. T. Hall

Double D Ranch

Horace Nichol

Frank Pollard

John R. Aboria

Nat Wolfe

20-404

General Development Corporation

Nat Wolfe

Jeff Fort

Nat Wolfe

Nichols Ranch

Dale Foster

General Development Corporation General Development Corporation G. V. Russe 1

General Development Corporation

General Development Corporation General Development Corporation General Development Corporation D. J. Thompson

Thornton

Hoffman

Robert Nunez

Firewel1

Carlston Field Mental Hospital

Calvin Boggess

Calvin Boggess

H. L. Johnson

Claude M. Johnson

Welles Fruit and Livestock

Stanley Sargent

\begin{tabular}{lr} 
Charlotte & $9-68$ \\
Charlotte & $11-65$ \\
Charlotte & $8-83$ \\
Charlotte & $3-84$ \\
De Soto & $4-71$ \\
& \\
De Soto & $8-70$ \\
De Soto & $4-71$ \\
De Soto & $4-71$ \\
De Soto & $4-71$ \\
De Soto & $8-62$ \\
& \\
De Soto & $4-69$ \\
De Soto & $8-62$ \\
De Soto & $7-62$ \\
De Soto & $4-71$ \\
De Soto & $8-83$ \\
De Soto & $12-74$ \\
De Soto & $4-71$ \\
De Soto & $6-62$ \\
De Soto & $8-68$ \\
De Soto & $4-71$ \\
De Soto & $6-62$ \\
De Soto & $8-73$ \\
De Soto & $9-72$ \\
De Soto & $8-70$ \\
De Soto & $8-73$ \\
De Soto & $12-74$ \\
De Soto & $12-74$ \\
De Soto & $2-75$ \\
De Soto & $1-72$ \\
De Soto & $12-74$ \\
De Soto & \\
De Soto & $10-68$ \\
De Soto & $4-71$ \\
De Soto & $12-65$ \\
De Soto & $12-65$ \\
De Soto & $1-71$ \\
De Soto & $1-71$ \\
De Soto & $4-71$ \\
De Soto & $3-71$ \\
De Soto & $3-71$ \\
\hline & \\
&
\end{tabular}




\begin{tabular}{|c|c|c|c|c|c|c|}
\hline \multicolumn{7}{|c|}{$\begin{array}{l}\text { Type of log and depth logged, } \\
\text { in feet below land-surface datum }\end{array}$} \\
\hline Electric & $\begin{array}{l}\text { Gamma- } \\
\text { ray }\end{array}$ & Caliper & $\begin{array}{c}\text { Fluid } \\
\text { conductivity }\end{array}$ & $\begin{array}{l}\text { Tempera- } \\
\text { ture }\end{array}$ & $\begin{array}{l}\text { Flow } \\
\text { meter }\end{array}$ & Other \\
\hline 259 & 259 & - & $\ldots$ & -- & - & $\ldots$ \\
\hline - - & 428 & 360 & - & - & - & - \\
\hline$\ldots$ & - - & 240 & $\ldots$ & 340 & - & - \\
\hline 829 & 829 & 829 & 829 & 829 & - & - \\
\hline 334 & 396 & 348 & - - & -- & - & -- \\
\hline 614 & 704 & 614 & - - & - - & - & - - \\
\hline 369 & 448 & 444 & $\ldots$ & - & $\ldots$ & $\ldots$ \\
\hline 346 & 400 & 348 & - & - & $\cdots$ & - \\
\hline 339 & 395 & -. & $\ldots$ & $\ldots$ & $\ldots$ & $\ldots$ \\
\hline 616 & 616 & -- & - & - & - & $\cdots$ \\
\hline 434 & 434 & 434 & $\ldots$ & $\ldots$ & -. & $\ldots$ \\
\hline 610 & 610 & $\ldots$ & $\ldots$ & $\ldots$ & $\ldots$ & - \\
\hline 1,211 & 1,211 & - & - & - & - & - \\
\hline 427 & 464 & 424 & - - & - - & - - & - \\
\hline 522 & 522 & 522 & 522 & 522 & - & - \\
\hline 449 & 496 & 440 & - & $\ldots$ & .. & $\ldots$ \\
\hline 629 & 624 & 620 & $\ldots$ & $\ldots$ & $\ldots$ & $\ldots$ \\
\hline 468 & 468 & $\ldots$ & $\ldots$ & $\ldots$ & - & -. \\
\hline 896 & 1,004 & 896 & 1,004 & 1,004 & $\ldots$ & - \\
\hline 333 & 368 & -- & - & - & $\cdots$ & - \\
\hline 460 & 460 & - & - & $\ldots$ & - & $\ldots$ \\
\hline 1,310 & 1,310 & 1,185 & - & - & -. & -. \\
\hline 1,085 & 1,184 & 1,083 & 1,180 & - & - & $\mathrm{f}$ \\
\hline 341 & 411 & 341 & - - & - & - & - - \\
\hline 1,310 & 1,310 & 1,185 & -- & - & - & $\cdots$ \\
\hline 535 & 535 & 535 & $\ldots$ & - & - & - \\
\hline 1,427 & 1,425 & 1,426 & $\ldots$ & $\ldots$ & - - & $\ldots$ \\
\hline 1,041 & 1,041 & 1,040 & 1,040 & $\ldots$ & $\ldots$ & - \\
\hline 1,009 & 1,068 & 1,009 & - & $\ldots$ & - & $f$ \\
\hline 868 & 860 & 860 & - & - & $\cdots$ & - \\
\hline 956 & - & - & - & - & $\ldots$ & $f$ \\
\hline 221 & 230 & $\cdots$ & - & $\cdots$ & - & $\cdots$ \\
\hline 508 & $\ldots$ & $\ldots$ & $\ldots$ & $\ldots$ & -. & - \\
\hline 535 & - & $\cdots$ & - & - & - & - \\
\hline 891 & 948 & 891 & -- & - & $\cdots$ & - \\
\hline- & 748 & 891 & $\ldots$ & - & - & $\ldots$ \\
\hline-- & 270 & - & -- & - & $\ldots$ & - \\
\hline 167 & 229 & 167 & - & - & -- & -- \\
\hline 1,057 & 1,125 & 1,125 & - & - & -- & $\mathrm{f}$ \\
\hline 454 & 561 & 492 & - & - & - & -- \\
\hline
\end{tabular}


271026081583601

271049081554101

271107081550501

271109081541901

271113081543301

271115081462601

271115081462701

271135081372501

271135081372501

271145081464801

271155081483801

271156081483901

271210081354301

271213081505001

271228081400801

271232081292201

271232081392201

271246081544301

271323081384702

271323081394201

271416081284701 271416081364601 271416081394301 271417081334901 271417081344801

271421081384701

271431081541401

271444081354701

271458081535801

271458082032101

271509081335001

271509081344901

271509081354801

271509081364701

271509081384101

271509081384601

271509081384602

271601081335001

271601081354801

271601081364601
ROMP \#17

Nat Wolfe

Phillip Berkowich

Minute Maid

Minute Maid

TR16 - 3

ROMP \#16

Bright Hour Ranch

Sebring and Myers

Nellie Brown

Nellie Brown

Bright Hour Ranch

\#1 Elevation Tank

De Soto Correctiona1 Institute

ROMP \#15

ROMP \#15

Myakka Processors Inc.

American Agronomics

Tropical River Groves J-I

Tropical River Groves

American Agronomics

Tropical River Groves J-2

Tropical River Groves

Tropical River Groves

Tropical River Groves J-8

D- 29

Tropical River Groves

M. Hollingsworth

Phillips Petroleum

Tropical River Groves

Tropical River Groves

Tropical River Groves

American Agronomics

Tropical River Groves

Tropical River Groves

American Agronomics

Tropical River Groves

American Agronomics

Tropical River Groves
De Soto

$12-84$

De Soto

De Soto

De Soto

De Soto

De Soto

De Soto

De Soto

De Soto

De Soto

De Soto

De Soto

De Soto

De Soto

De Soto

De Soto

De Soto

De Soto

De Soto

De Soto

De Soto

De Soto

De Soto

De Soto

De Soto

De Soto

De Soto

De Soto

De Soto

De Soto

De Soto

De Soto

De Soto

De Soto

De Soto

De Soto

De Soto

De Soto

De Soto

De Soto
$8-70$

4-71

4-71

$8-70$

$10-79$

$6-84$

$9-69$

$2-71$

9-62

4-70

9-62

$2-71$

10-64

11-71

5- 84

$6-85$

10-69

4- 70

$12-68$

1-76

$1-71$

2- 69

$5-72$

11-71

$10-69$

$8-62$

$1-72$

4-71

1-75

$5-72$

9-71

9-71

10-70

9-69

9- 69

12-69

$1-71$

$11-70$

$7-70$ 
Type of $\log$ and depth logged, in feet below land-surface datum

\begin{tabular}{|c|c|c|c|c|c|c|}
\hline Electric & $\begin{array}{l}\text { Gamma- } \\
\text { ray }\end{array}$ & Caliper & $\begin{array}{c}\text { Fluid } \\
\text { conductivity }\end{array}$ & $\begin{array}{c}\text { Tempera- } \\
\text { ture }\end{array}$ & $\begin{array}{l}\text { Flow } \\
\text { meter }\end{array}$ & Other \\
\hline 832 & - & 830 & - & 832 & - & $\mathrm{n}$ \\
\hline 459 & 543 & 440 & - & - & - & - \\
\hline 340 & 428 & - - & - & - - & - & - - \\
\hline 240 & 320 & - & - & - & - & - \\
\hline 284 & -- & 284 & -- & -- & - & -- \\
\hline 502 & 940 & 642 & 542 & 882 & - & $\ldots$ \\
\hline 940 & 942 & - & 500 & 938 & - & $\mathrm{s}, \mathrm{n}$ \\
\hline 1,298 & 1,478 & 1,478 & - & -. & $\cdots$ & $\ldots$ \\
\hline 1,298 & 1,478 & -. & - - & - - & - - & - - \\
\hline 439 & 439 & -- & - & - & - & $\cdots$ \\
\hline 284 & 327 & - & - & - & - & -- \\
\hline 327 & 327 & $\ldots$ & $\ldots$ & - & - & $\cdots$ \\
\hline 230 & 310 & - & - & - - & - & - \\
\hline 387 & 387 & - - & - - & - - & - & - - \\
\hline 321 & -- & 348 & -- & - - & - & -- \\
\hline 575 & 580 & 575 & -- & - & - & - \\
\hline 1,372 & - & - & 1,372 & 1,372 & - - & -. \\
\hline 1,229 & - - & - & - & - & - & $\ldots$ \\
\hline 1,246 & 730 & - & - - & - - & - - & - \\
\hline 804 & 804 & 804 & 780 & - & $\ldots$ & $\ldots$ \\
\hline 328 & - & 328 & - & 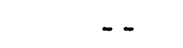 & - & -- \\
\hline 1,132 & - - & 1,337 & - - & - - & $\ldots$ & - \\
\hline 1,404 & 1,404 & - - & - - & - - & - & - \\
\hline 1,328 & 1,406 & 1,328 & - - & $\cdots$ & - - & - \\
\hline 632 & -- & 632 & $\cdots$ & -- & - & - \\
\hline 999 & 999 & $\cdots$ & $\cdots$ & $\cdots$ & - & - \\
\hline 316 & 316 & - & - & - & - - & - - \\
\hline 1,121 & 1,295 & 1,122 & - & 1,253 & - & $\mathrm{f}$ \\
\hline$\cdots$ & 489 & - & - & - - & - - & - - \\
\hline 1,486 & 320 & 1,500 & - & 1,500 & - & - \\
\hline 824 & 1,016 & -- & $\ldots$ & - & - & - \\
\hline 1,158 & 1,322 & 1,157 & - & - & - & - \\
\hline 957 & 1,113 & 1,054 & - & - & - & .. \\
\hline 1,146 & 1,322 & 1,146 & - & - - & - - & - \\
\hline 516 & -- & -- & - & - & -- & -- \\
\hline 516 & - & - & - - & $\ldots$ & $\ldots$ & $\ldots$ \\
\hline 246 & 266 & - & $\ldots$ & $\ldots$ & $\ldots$ & - \\
\hline 720 & - & 720 & - & - & - & - \\
\hline 1,144 & 1,806 & 1,144 & - & - & - & - \\
\hline 1,160 & 1,316 & 1,314 & - & - & - & - \\
\hline
\end{tabular}


271601081374601 271618081590901 271623081515901 271623081520101 271654081374601

271654081384602 271729081403003 271743081374602 271746081384601 271746081404301

271800081493001 271834081530401 271841081572101 271854082012001 272012081482301

272511081494101 271431081541401 272340081475401 272404081553401 272503081545601

272557081535201 272701081394901 272703081480801 272715081580001 272728081474701

272739081423501 272800081484301 272807081585901 272932081492001 273103081363701

273135081480101 273156081451401 273205081433001 273220081493201 273250081480801

273251081494601 273331081414601 273411082025101 273421081361401
American Agronomics

V. C. Hollingsworth

Camp Chanyatah

Camp Chanyatah

American Agronomics

Tropical River Groves

U.S. Geological Survey

American Agronomics

American Agronomics

S. Tomatoes Growers

ROMP 26

Bruning

D. E. Carlton

Walter Bethe 1

D. E. Marshall

$20-1017$

Joe Burtscher

B. H. Griffin

Robert Norris

Ervin Shapario

Hardee Groves Inc.

Willis Beatty

Albitton Farm

ROMP 31

ROMP 30 S. S. Slaughter

New wel1 - Repub1ic Groves

G. S. Slaughter

I.M.C.

John F. Martins

M. A. Smith

Wheeler Farms Inc.

C. E. Trimmer

Charles Adler

J. W. Cherry

City of Wauchula

Joe L. Davis

Sam Trogden

W. J. Durrance

M. A. Smith

\begin{tabular}{|c|c|}
\hline De Soto & $2-70$ \\
\hline De Soto & $9-62$ \\
\hline De Soto & $11-71$ \\
\hline De soto & $11-71$ \\
\hline De Soto & $5-73$ \\
\hline De Soto & $8-74$ \\
\hline De Soto & $4-75$ \\
\hline De Soto & $4-70$ \\
\hline De Soto & $12-69$ \\
\hline De Soto & $11-71$ \\
\hline De Soto & $8-82$ \\
\hline De Soto & $12-62$ \\
\hline De Soto & $3-72$ \\
\hline De Soto & $6-73$ \\
\hline De Soto & $7-62$ \\
\hline De Soto & $6-85$ \\
\hline De Soto & $9-62$ \\
\hline Hardee & $1-72$ \\
\hline Hardee & $3-72$ \\
\hline Hardee & $8-62$ \\
\hline Hardee & $8-62$ \\
\hline Hardee & $8-62$ \\
\hline Hardee & $9-62$ \\
\hline Hardee & $8-76$ \\
\hline Hardee & $2-81$ \\
\hline Hardee & $8-62$ \\
\hline Hardee & $1-72$ \\
\hline Hardee & $6-73$ \\
\hline Hardee & $1-72$ \\
\hline Hardee & $8-62$ \\
\hline Hardee & $8-72$ \\
\hline Hardee & $7-62$ \\
\hline Hardee & $8-62$ \\
\hline Hardee & $12-62$ \\
\hline Hardee & $8-63$ \\
\hline Hardee & $1-72$ \\
\hline Hardee & $11-74$ \\
\hline Hardee & $8-62$ \\
\hline $\mathrm{H}$ & $12-62$ \\
\hline
\end{tabular}


Type of $\log$ and depth logged, in feet below land-surface datum

\begin{tabular}{|c|c|c|c|c|c|c|}
\hline Electric & $\begin{array}{l}\text { Gamma- } \\
\text { ray }\end{array}$ & Caliper & $\begin{array}{c}\text { Fluid } \\
\text { conductivity }\end{array}$ & $\begin{array}{c}\text { Tempera- } \\
\text { ture }\end{array}$ & $\begin{array}{l}\text { Flow } \\
\text { meter }\end{array}$ & Other \\
\hline 716 & 916 & 916 & - - & $\ldots$ & $\ldots$ & - \\
\hline - - & 1,252 & - - & - - & - & - - & - - \\
\hline 164 & 194 & $\ldots$ & - - & - - & -- & - - \\
\hline 149 & 183 & - & - - & -- & - & -- \\
\hline 1,110 & 1,260 & 1,158 & -- & -- & $\cdots$ & -- \\
\hline 1,358 & 1,358 & 1,360 & -- & -- & -- & - - \\
\hline & 839 & 250 & -- & -- & - & -- \\
\hline 1,203 & 1,343 & 1,230 & - & $\cdots$ & $\cdots$ & - \\
\hline 1,032 & 1,248 & - - & - & $\cdots$ & $\cdots$ & -- \\
\hline 850 & 1,243 & 851 & -- & -- & $\cdots$ & - \\
\hline - - & 250 & 250 & 334 & 263 & $\ldots$ & - - \\
\hline 664 & 650 & - & - - & - & $\ldots$ & - - \\
\hline 810 & 956 & 809 & -- & -- & $\cdots$ & -- \\
\hline 1,289 & 1,433 & -- & -- & -- & - & $\cdots$ \\
\hline 478 & 478 & $\cdots$ & - & - & - & -- \\
\hline 1,062 & 1,062 & 1,062 & 1,062 & 1,062 & $\ldots$ & - \\
\hline 316 & - & -- & -- & - & $\cdots$ & -- \\
\hline 186 & 260 & 186 & $\cdots$ & - & $\cdots$ & - \\
\hline 961 & 1,067 & 960 & -- & -- & - & - \\
\hline 820 & 824 & -- & -- & -- & - & -- \\
\hline 1,080 & 1,080 & -- & -- & $\cdots$ & $\cdots$ & - \\
\hline 638 & 638 & - & -- & -- & $\cdots$ & $\cdots$ \\
\hline 1,134 & 1,132 & -- & $\cdots$ & -- & - & - \\
\hline 1,144 & 1,144 & 1,144 & 1,144 & 1,144 & - & -- \\
\hline 365 & 365 & 365 & -- & -- & $\cdots$ & -- \\
\hline 860 & 850 & - - & -- & - & $\cdots$ & -- \\
\hline 269 & 310 & 269 & $\cdots$ & -- & -- & -- \\
\hline 223 & 346 & - & $\cdots$ & -- & -- & -- \\
\hline 143 & 173 & 143 & $\cdots$ & $\cdots$ & $\cdots$ & -- \\
\hline 849 & 849 & -- & $\cdots$ & $\cdots$ & -- & -- \\
\hline-- & 246 & 199 & - & -- & - & - \\
\hline 267 & 267 & -- & -- & -- & $\cdots$ & -- \\
\hline 658 & 658 & -- & -- & -- & -- & - \\
\hline 546 & 540 & -- & $\cdots$ & $\cdots$ & - & -- \\
\hline 1,103 & 1,103 & -- & $\cdots$ & $-\cdot$ & -- & -- \\
\hline 288 & 346 & 288 & $\cdots$ & - & - & -- \\
\hline 1,194 & 1,193 & 1,194 & $\cdots$ & -- & $\cdots$ & -- \\
\hline 1,062 & 1,062 & -- & -- & - & $\cdots$ & - - \\
\hline 1,172 & -- & -- & - & -- & $\cdots$ & - - \\
\hline
\end{tabular}


273708081435401

271553081208401

271708081220001

273615081284901

270704082471201

274032082150001

274058082282801

274201082212501

274203082290901

274228082081801

274240082212703

274243082211503

274252082232401

274256082201601

274315082201701

274352082061001

274400082070801

274403082200901

274407082250501

274407082260901

274408082222301

274410082230701

274412082071401

274412082071402

274414082200901

274424082083501

274427082083703

274455082245501

274503082252001

274530082154401

274628082240301

274630082191301

274722082200701

274745082041001

274745082041301

274745082041601 274752082234001

274857082195301

274907082195301

274919082194701
S. J. Tilden

ROMP 28x

1013

ROMP 43xx

TR11 - 2

ROMP 123

23

Hi11sborough

45

G. Hood

ROMP 50

SWFWMD

Hillsborough County

Hillsborough County

Hillsborough County

Brewster \#7

Hi11sborough County

P. Pickman

W. H. Winis

Council Farms

Hillsborough

Brewster

Brewster

E11sberry

ROMP 48

ROMP 48

Replacement Council

Shakey

ROMP 49

E11sberry

First Offenders (State)

Fisher

I.M.C.

I.M.C.

I.M.C.

$11-10$

Hi11sborough County

Hillsborough County

Hillsborough County
Hardee

Highlands

Highlands

Highlands

Hillsborough

Hillsborough

Hillsborough

Hi1lsborough

Hillsborough

Hillsborough

Hi11sborough

Hillsborough

Hillsborough

Hillsborough

Hillsborough

Hi11sborough

Hillsborough

Hillsborough

Hillsborough

Hillsborough

Hi11sborough

Hillsborough

Hillsborough

Hillsborough

Hillsborough

Hillsborough

Hi1lsborough

Hillsborough

Hillsborough

Hil1sborough

Hillsborough

Hillsborough

Hi11sborough

Hi11sborough

Hillsborough

Hi11sborough

Hillsborough

Hillsborough

Hillsborough

Hillsborough
$1-72$

$10-82$

$11-83$

$1-82$

$3-79$

$2-77$

$6-76$

$6-75$

$6-76$

$3-74$

$5-82$

$12-76$

$3-76$

$11-74$

$11-74$

$3-76$

$8-75$

$3-76$

$7-76$

$7-76$

$7-76$

$6-76$

3-75

3-75

3-76

$2-76$

4-73

6-80

$6-76$

1- 77

$6-76$

$2-75$

4-76

$12-74$

$2-75$

$12-74$

4-85

3-69

2-69

2- 69 


\begin{tabular}{|c|c|c|c|c|c|c|}
\hline \multicolumn{7}{|c|}{$\begin{array}{c}\text { Type of log and depth logged, } \\
\text { in feet below land-surface datum }\end{array}$} \\
\hline Electric & $\begin{array}{l}\text { Gamma- } \\
\text { ray }\end{array}$ & Caliper & $\begin{array}{c}\text { Fluid } \\
\text { conductivity }\end{array}$ & $\begin{array}{c}\text { Tempera- } \\
\text { ture }\end{array}$ & $\begin{array}{l}\text { Flow } \\
\text { meter }\end{array}$ & Other \\
\hline 932 & 1,066 & 332 & - & - & - & - \\
\hline 1,388 & 1,387 & 1,388 & 1,388 & 1,388 & - - & - - \\
\hline 1,630 & 1,630 & 1,630 & 1,630 & 1,630 & -- & - \\
\hline 1,120 & 1,130 & 1,130 & 1,030 & 1,030 & - - & - - \\
\hline 587 & 587 & - - & 587 & 476 & -- & -- \\
\hline$\ldots$ & 598 & 598 & 598 & 598 & - & - \\
\hline - & 628 & 630 & - - & 610 & - - & - - \\
\hline 478 & 550 & 551 & $\ldots$ & - & - & - - \\
\hline - & 444 & 448 & 446 & -- & -- & -- \\
\hline 569 & 862 & 585 & 384 & -- & -- & -- \\
\hline 640 & 934 & 1,439 & 1,500 & 1,500 & - & - \\
\hline - - & -- & 930 & 1,465 & 880 & -- & - - \\
\hline 266 & 456 & $\cdots$ & - - & 488 & - - & -- \\
\hline 584 & 656 & 500 & - & - & -- & -- \\
\hline 356 & 591 & 364 & -- & -- & -- & -- \\
\hline- & 154 & 38 & - - & - & - - & - - \\
\hline$\ldots$ & - & 60 & -- & 40 & - - & $\mathrm{f}$ \\
\hline 260 & 476 & - & 225 & 400 & - & -- \\
\hline - - & - - & 458 & 460 & - - & - & -- \\
\hline- & -- & 154 & 140 & - & -- & - - \\
\hline - - & 828 & 828 & 814 & - & - & - \\
\hline-- & 844 & 845 & 832 & 849 & - & - \\
\hline 175 & 172 & - & - - & - & - - & - - \\
\hline 130 & - - & 144 & - - & - - & - - & - - \\
\hline-- & 758 & 673 & -- & -- & -- & -- \\
\hline 215 & 215 & 215 & - - & 215 & - - & - - \\
\hline 919 & 919 & 919 & 919 & 919 & - - & - - \\
\hline 306 & 306 & 302 & -- & -- & - & - - \\
\hline- & 533 & 530 & 533 & 516 & - - & - - \\
\hline 618 & 618 & 618 & 618 & 618 & -- & -- \\
\hline-- & 394 & 389 & 394 & 378 & -- & - - \\
\hline 380 & 487 & 355 & - - & - & - & - - \\
\hline - - & - - & 162 & -- & -- & - - & - - \\
\hline 190 & 289 & 220 & -- & - & -- & - \\
\hline 111 & 192 & 188 & -- & - & -- & -- \\
\hline 949 & 940 & 908 & - & - & - - & - - \\
\hline - & - - & 320 & - & - & - - & - \\
\hline 384 & 594 & - - & - & - & - & - \\
\hline 376 & 586 & - & 540 & - & -- & - \\
\hline 382 & 592 & - & 548 & - - & - - & - - \\
\hline
\end{tabular}


275001082153702

275045082223301

275055082095301

275152082035801

275200082085401

275215082201901 275322082285201 275337082171701 275337082181001 275425082222701

275429082094101 275505082175301 275508082164401 275551082062701 275657082251601

275711082032901 275711082032901 275731082123201

275736082162001 275747082183901

275833082165501 280154082205001 280331082203601 280354082381901 263818082020901

264302081445001 264323082153001 264435082153801 271611082050201 271743082103601

271832082064801 271852082104101 271852082104101 271940082080201 272034082120101

272034082145201 272047082114401 272102082100601 272242082235501 272332082305901
Connie Espy

Clava Tanner

Hills. County, Pinecrest School

Seaboard Airline Railroad

EMW - 4

U.S. Phosphoric

Florida Bureau of Geology

Bloomingdale

Country Side

SWFWMD TR-10-2

ROMP 61

Hillsborough County

Hillsborough County

K. W. Bakley

City of Tampa

City of Tampa

Lamb

Gables

Kingsway Downs

Hillsborough County

Hillsborough County

Anderson

ROMP 67-1

City of St. Petersburg

Pine Island

Ow1 Creek

Seaboard Airline Railroad

Boca Grand Mobile Hotel

J . J . Ranch

U.S. Geological Survey

ROMP 23-2

ROMP 23-1

Babcock \#1

Green

Russ and Pulnal

Foxworthy

01d We11 Myakka

Schroeder

Crescent Farms
Hillsborough

Hillsborough

Hillsborough

Hillsborough

Hillsborough

Hillsborough

Hillsborough

Hillsborough

Hillsborough

Hillsborough

Hillsborough

Hillsborough

Hillsborough

Hillsborough

Hillsborough

Hillsborough

Hillsborough

Hillsborough

Hillsborough

Hillsborough

Hillsborough

Hillsborough

Hillsborough

Hillsborough

Lee

Lee

Lee

Lee

Manatee

Manatee

Manatee

Manatee

Manatee

Manatee

Manatee

Manatee

Manatee

Manatee

Manatee

Manatee
$2-75$

$6-76$

3-69

11-81

$7-83$

$6-76$

2-72

4-76

4-77

5-78

$1-78$

$11-76$

$11-76$

$6-68$

6-66

5-71

3-76

3-76

4-77

7-76

$7-76$

$1-76$

3-79

$6-73$

10-71

4-69

$8-65$

5- 62

7-64

7-64

$7-65$

2- 79

3-79

$9-73$

$9-65$

4- 62

$12-63$

5- 62

4-78

$12-79$ 


\begin{tabular}{|c|c|c|c|c|c|c|}
\hline \multicolumn{7}{|c|}{$\begin{array}{l}\text { Type of log and depth logged, } \\
\text { in feet below land-surface datum }\end{array}$} \\
\hline Electric & $\begin{array}{l}\text { Gamma- } \\
\text { ray }\end{array}$ & Caliper & $\begin{array}{c}\text { Fluid } \\
\text { conductivity }\end{array}$ & $\begin{array}{c}\text { Tempera- } \\
\text { ture }\end{array}$ & $\begin{array}{l}\text { Flow } \\
\text { meter }\end{array}$ & Other \\
\hline 158 & 197 & 193 & 150 & - & $\ldots$ & - \\
\hline- & 164 & 164 & 163 & -- & -- & -- \\
\hline 181 & 280 & -- & $\cdots$ & -- & -- & $\cdots$ \\
\hline 169 & 206 & 202 & - & - & -- & -- \\
\hline 902 & 902 & 902 & 902 & 902 & -- & -- \\
\hline- & 648 & 648 & 649 & 611 & - & $\cdots$ \\
\hline 392 & 392 & 392 & - & -- & - & -- \\
\hline 256 & 370 & 272 & 352 & 346 & -- & -- \\
\hline - - & 197 & 206 & 176 & - & - - & - \\
\hline 459 & 465 & 465 & 459 & 459 & - & - \\
\hline 995 & 998 & 1,000 & -- & 995 & - & - \\
\hline- & 340 & 340 & 245 & -- & - & - \\
\hline- & 195 & 202 & - & - & -- & -- \\
\hline 672 & 730 & 674 & 672 & 672 & - & - \\
\hline - - & 692 & 650 & -- & -- & -- & -- \\
\hline 201 & 637 & 196 & - & - & - & - \\
\hline-- & 55 & 54 & -- & -- & -- & -- \\
\hline- & 73 & 52 & -- & - & - & - \\
\hline-- & 343 & 350 & 287 & 274 & - & - \\
\hline- & - & 263 & 225 & - & -- & -- \\
\hline- & - & - & 293 & $\ldots$ & $\ldots$ & $\ldots$ \\
\hline 48 & 48 & 48 & - & - & - & - \\
\hline 442 & 442 & - & 442 & 442 & - & - \\
\hline- & - - & - & 424 & - & -- & - \\
\hline 978 & -- & -- & 978 & - & -- & -- \\
\hline- & - & 458 & 458 & $\ldots$ & - & - \\
\hline 250 & 571 & 387 & -- & -- & -- & -- \\
\hline 197 & 197 & - & -- & - & -- & - \\
\hline 1,080 & 1,080 & -- & -- & -- & -- & -- \\
\hline 1,324 & 1,324 & -- & -- & -- & -- & -- \\
\hline 585 & 598 & 576 & -- & -- & -- & - \\
\hline 432 & 363 & 432 & 374 & 364 & -. & - \\
\hline 432 & -. & 432 & - & - & - & - \\
\hline 1,382 & 1,382 & 1,382 & - & - & - & - \\
\hline 909 & 909 & -- & -- & -- & -- & -- \\
\hline 962 & 962 & - & - & - & - & - \\
\hline 644 & 644 & -- & -- & -- & -- & -- \\
\hline 539 & 539 & -- & -- & -- & -- & -- \\
\hline-- & 1,092 & -- & -- & -- & -- & -- \\
\hline 614 & 628 & 612 & -- & -- & -- & -- \\
\hline
\end{tabular}


272337082305901

272356082181301

272404082161701

272417082350901

272438082325201

272447082302301 272505082331001

272505082331401

272510082345701

272513082333801

272523082033601

272523082033601

272533082292601

272540082405001

272545082410401

272546082405501

272557082302301

272558082360601

272610082353802

272647082183401

272700082315301

272708082343101

272730082083401

272731082054601

272735082083401

272750082415401 272758082415301 272810082283201

272825082380201

272829082220101

272838082142201

272838082142401

272854082373401

272902082364601

272918082370601

272924082405001

272925082405101

272925083362501

272926082370301

272931082331901
Crescent Farms

U.S. Geological Survey

City of Sarasota

Club Longboat

Midway Groves

Clyde Bradley

Manatee County

Manatee County

TR7 - 1

Whitfield Estates Water System

Horace Gough

Horace Gough

TR7 - 3

Peek \#3

Whitney Beach

Peek \#4

Manatee Fruit Company

E1 Conquistador Golf Course

Manatee Junior College

Hunsader Brothers

Reasoner Nursery

U.S. Geological Survey

Pass Grove

U.S. Geological Survey

Pine Trails Park

Azure Shores Well Association

21-1003

L. Turner

Manatee Schroeder

Kibler Ranch

Kibler Ranch

Freedom Village

West Coast Marketing Company

West Coast Marketing Company

$21-1002$

21-1001

Bradenton Country Club

West Coast Marketing Company

Tropicana
Manatee

Manatee

Manatee

Manatee

Manatee

Manatee

Manatee

Manatee

Manatee

Manatee

Manatee

Manatee

Manatee

Manatee

Manatee

Manatee

Manatee

Manatee

Manatee

Manatee

Manatee

Manatee

Manatee

Manatee

Manatee

Manatee

Manatee

Manatee

Manatee

Manatee

Manatee

Manatee

Manatee

Manatee

Manatee

Manatee

Manatee

Manatee

Manatee

Manatee
$12-79$

$5-65$

$11-78$

$11-72$

$11-65$

4-74

$10-71$

$11-71$

7-81

5-61

5- 65

$5-62$

6- 80

4-77

9-64

4-77

$1-73$

$10-72$

$5-73$

$10-78$

$10-72$

$6-76$

$11-65$

$12-62$

11- 65

$8-77$

$3-72$

2- 85

3- 68

4- 78

4- 78

4-78

5-84

11- 67

7-65

2- 85

2-85

10-64

4-76 


\begin{tabular}{|c|c|c|c|c|c|c|}
\hline \multicolumn{7}{|c|}{$\begin{array}{l}\text { Type of } \log \text { and depth logged, } \\
\text { in feet below land-surface datum }\end{array}$} \\
\hline Electric & $\begin{array}{c}\text { Gamma- } \\
\text { ray }\end{array}$ & Caliper & $\begin{array}{c}\text { Fluid } \\
\text { conductivity }\end{array}$ & $\begin{array}{c}\text { Tempera- } \\
\text { ture }\end{array}$ & $\begin{array}{l}\text { Flow } \\
\text { meter }\end{array}$ & Other \\
\hline 325 & 337 & 336 & - & $\cdots$ & $\cdots$ & $\cdots$ \\
\hline 448 & - & $\cdots$ & $\cdots$ & $\cdots$ & - & - \\
\hline - & 469 & $\cdots$ & $\cdots$ & $\cdots$ & $\cdots$ & $\cdots$ \\
\hline 433 & 433 & 433 & $\cdots$ & $\cdots$ & - & $\cdots$ \\
\hline 796 & 796 & 794 & $\cdots$ & $\cdots$ & -- & $\cdots$ \\
\hline 436 & 488 & 439 & $\ldots$ & $\cdots$ & - & - \\
\hline - - & 79 & 67 & $\cdots$ & - & - & - - \\
\hline 53 & 76 & 53 & - & $\cdots$ & $\cdots$ & - \\
\hline 630 & 630 & 629 & 630 & 630 & 560 & $\cdots$ \\
\hline 659 & $\cdots$ & - & - & - & $\cdots$ & -- \\
\hline 1,204 & 1,204 & 1,202 & 1,204 & $\cdots$ & $\cdots$ & $\cdots$ \\
\hline - - & 1,204 & 1,202 & - & $\cdots$ & - & $\cdots$ \\
\hline 620 & - & 630 & 632 & 620 & $\cdots$ & $s, n$ \\
\hline 411 & 411 & 411 & 411 & 411 & -- & -- \\
\hline 228 & $\cdots$ & $\cdots$ & $\cdots$ & $\cdots$ & $\cdots$ & $\cdots$ \\
\hline 409 & $\cdots$ & 410 & 410 & 410 & - & $\cdots$ \\
\hline 652 & 756 & 656 & $\cdots$ & $\cdots$ & $\cdots$ & $\cdots$ \\
\hline 350 & 395 & 308 & - & - & - & - - \\
\hline 12 & 22 & 12 & $\cdots$ & $\cdots$ & $\cdots$ & $\cdots$ \\
\hline 1,049 & 1,226 & 1,207 & - & -- & -- & $\cdots$ \\
\hline 475 & 500 & 473 & $\cdots$ & $\cdots$ & - & - - \\
\hline-- & 295 & 293 & $\cdots$ & $\cdots$ & - & $\cdots$ \\
\hline 548 & 548 & 548 & $\cdots$ & 548 & - & $\cdots$ \\
\hline 1,198 & 1,198 & - & $\cdots$ & - & -- & - \\
\hline 548 & $\cdots$ & 548 & $\cdots$ & -- & -- & -- \\
\hline-- & 381 & 381 & $\cdots$ & 381 & - & - \\
\hline 291 & 291 & 289 & $\cdots$ & $\cdots$ & - - & - \\
\hline-- & -- & 473 & $\cdots$ & 476 & - - & - - \\
\hline 586 & 586 & 586 & 586 & -- & -- & $f$ \\
\hline 1,002 & 1,088 & 982 & - & -- & - - & - - \\
\hline 941 & 1,115 & - - & $\cdots$ & - & - & - - \\
\hline 941 & 1,115 & 1,108 & - - & $\cdots$ & -- & - - \\
\hline - - & - & 643 & - & - & - & - - \\
\hline 564 & -- & $\cdots$ & - & - & -- & -- \\
\hline 525 & -- & $\cdots$ & -- & -- & -- & - \\
\hline - - & $\cdots$ & 200 & - & $\cdots$ & - - & - - \\
\hline - & $\cdots$ & 276 & -- & -- & -- & -- \\
\hline 672 & 672 & $\cdots$ & - & -- & - - & - - \\
\hline 657 & $-\cdot$ & -- & - & - & -- & -- \\
\hline 899 & 956 & 944 & 943 & $\cdots$ & -- & -- \\
\hline
\end{tabular}


We11 number

Local name

County

Date

272939082382101

272945082373701

272945082382101

272946082380401

272948082285301

272949082404001

272956082410201

273000082065101

273009082250601

273031082380701

273031082380701

273044082385401

273047082333301

273048082385201

273113082334601

273121082344401

273129082354401

273129082430201

273131082430301

273132082314901

273207082343701

273207082343701

273213082034001

273228082314301

273252082072401

273304082334701

273332082333201

273333082332901

273403082332201

273406082332801

273427082291001

273427082291001

273458082324601

273458082324701

273511082060401

273548082253301

273556082151201

273559082251901

273618082173601

273618082173601
Old Palma Sola Park

Consumer's Utilities Inc.

$\mathrm{J}$. L. Holding Company

Manatee Royal Palms Inc.

Perico Island

Manatee Fruit Company

Beker

C. L. Regan

Freedland

Freedland

21-480

Manatee Civic Center

Lynch Nursery

$21-450$

$21-563$

City of Palmetto

Key Royale Country Club \#2

Key Royale Country Club \#3

Manson Cemetary 21-445

Manatee Fruit Company

Manatee Fruit Company

Crescent D Ranch

Roach

Swift Chemical Company

State Road Department

Skyway Mobile Home Park

Skyway Mobile Home Park

Paisley and Stone

$21-458$

Lyndee Dairy

Lyndee Dairy

SWFWMD

TR8 - 1

Duette Ranch

$21-558$

Norda Ranch

Heller Corporation

Florida Power and Light

Florida Power and Light
Manatee

$5-73$

Manatee

$4-76$

$7-62$

4-76

Manatee

5-65

Manatee

4-75

Manatee

$3-71$

Manatee

9-76

$3-71$

Manatee

$10-63$

Manatee

$3-71$

Manatee

4-85

$6-83$

Manatee

$11-70$

Manatee

8-83

Manatee

2- 85

7-71

3-71

$3-71$

$8-83$

Manatee

4-79

4- 79

$12-62$

$7-83$

$2-75$

Manatee

10-63

$3-71$

$3-71$

$3-71$

Manatee

Manatee

$12-83$

Manatee

$5-77$

Manatee

5-72

2- 80

Manatee

$12-82$

Manatee

$3-72$

Manatee

$2-85$

Manatee

$6-76$

$6-76$

4-75

Manatee

4- 75 


\begin{tabular}{|c|c|c|c|c|c|c|}
\hline \multicolumn{7}{|c|}{$\begin{array}{l}\text { Type of } 1 \text { og and depth logged, } \\
\text { in feet below land-surface datum }\end{array}$} \\
\hline Electric & $\begin{array}{l}\text { Gamma- } \\
\text { ray }\end{array}$ & Caliper & $\begin{array}{c}\text { Fluid } \\
\text { conductivity }\end{array}$ & $\begin{array}{c}\text { Tempera- } \\
\text { ture }\end{array}$ & $\begin{array}{l}\text { F1ow } \\
\text { meter }\end{array}$ & Other \\
\hline 275 & 530 & -. & - & - & -. & -. \\
\hline 507 & - & 524 & $\cdots$ & - & $\cdots$ & - \\
\hline 325 & 325 & - & - & -. & -. & $\cdots$ \\
\hline 256 & 250 & 250 & - & - & - & - \\
\hline 452 & - & $\cdots$ & -- & -- & $\cdots$ & $\cdots$ \\
\hline 598 & 596 & 490 & 595 & - & - & - \\
\hline 615 & 615 & $\cdots$ & 615 & $\cdots$ & $\cdots$ & $\mathrm{f}$ \\
\hline - & 1,244 & 1,244 & $\cdots$ & - & $\cdots$ & - \\
\hline 653 & 653 & - & - & 653 & -- & $f$ \\
\hline 559 & 559 & $\cdots$ & -- & $\cdots$ & -- & - \\
\hline 559 & 631 & - & 631 & $\cdots$ & $\cdots$ & $\mathrm{f}$ \\
\hline$\cdots$ & $\cdots$ & 171 & $\cdots$ & 171 & - & - \\
\hline 281 & 281 & 281 & - & 281 & $\cdots$ & $\cdots$ \\
\hline 460 & 648 & - & - & -. & - & - \\
\hline- & - & 487 & - & 487 & - & $-\cdot$ \\
\hline - & -. & 267 & $\ldots$ & 267 & - & - \\
\hline 356 & 551 & 350 & $\cdots$ & $\cdots$ & - & $\cdots$ \\
\hline 452 & - & 452 & 452 & 452 & $\cdots$ & $\mathrm{f}$ \\
\hline 402 & 402 & 402 & 402 & 402 & - & $f$ \\
\hline$\cdots$ & -- & 548 & - & 548 & -. & - \\
\hline 603 & 609 & 609 & - & $\cdots$ & -. & -. \\
\hline 603 & - & 609 & - & - & - & -. \\
\hline 591 & 560 & - & - & - & - & - - \\
\hline 566 & 566 & 424 & 566 & $\cdots$ & - & - \\
\hline 845 & 1,207 & 884 & - & - & $\cdots$ & - \\
\hline 522 & - & $\ldots$ & $\ldots$ & - & -. & -- \\
\hline 226 & 226 & $\cdots$ & -- & 226 & $\cdots$ & $f$ \\
\hline 403 & 403 & 403 & - & $\cdots$ & - & $\mathrm{f}$ \\
\hline 566 & 566 & 566 & - & $\cdots$ & - & - \\
\hline$\cdots$ & $\cdots$ & 401 & $\cdots$ & 401 & $\cdots$ & $\cdots$ \\
\hline- & - & 437 & - & - & $\cdots$ & - \\
\hline - & $\cdots$ & 437 & $\cdots$ & $\cdots$ & - & - \\
\hline 372 & 541 & 488 & 388 & 388 & - & -. \\
\hline 785 & 785 & 785 & 785 & 785 & - & -. \\
\hline 862 & 981 & 862 & $\cdots$ & - & $\cdots$ & $\cdots$ \\
\hline - & - & 380 & -. & 380 & -. & - \\
\hline 295 & - & - & $\cdots$ & - & -. & $\ldots$ \\
\hline 811 & 780 & - & $\cdots$ & -. & -. & - \\
\hline 947 & 1,040 & 947 & $\cdots$ & $\cdots$ & $\cdots$ & - \\
\hline 947 & 1,040 & 947 & $\cdots$ & $\cdots$ & $\cdots$ & -- \\
\hline
\end{tabular}


273633082174901 273718082315401 273718082315501 273724082305602 273724082314103

273728082313201 273728082320101 273732082312801 273736082315503 273738082312603

273743082322301 273745082321301

273745082322201

273747082315201 273749082314003

273753082324101 273756082330201

273757082325701

273759082251901

273811082250401

273815082074201 273817082194002 270750082465401 274745082443205 274748082443905

274751082444105 274751082444406 274753082444307 274753082444706 274754082444105

274754082444505 274922082443101 275047082401601 275430082431401 275458082464001

275459082481202 275500082444702 275501082463102 275625082474801 275704082475501
Florida Power and Light Willis Farm

E.B.A.S.C.O. Borden Chemical Borden Chemical

Borden Chemical Borden Chemical Borden Chemical Borden Chemical Borden Chemical

Borden Chemical Borden Chemical Borden Chemical Borden Chemical Borden Chemical

Manatee Port Authority \#4 Manatee Port Authority Manatee Port Authority Heller Corporation Isadora Hecht

Weinstock

Florida Power and Light TRI5-1A

U.S. Geological Survey

U.S. Geological Survey

U.S. Geological Survey U.S. Geological Survey U.S. Geological Survey U.S. Geological Survey U.S. Geological Survey

U.S. Geological Survey Pinellas County

City of St. Petersburg TR13-2x

TR13-1x

U.S. Geological Survey

U.S. Geological Survey

U.S. Geological survey

City of Clearwater Well \#35

City of Clearwater Well \#24
Manatee

Manatee

Manatee

Manatee

Manatee

Manatee

Manatee

Manatee

Manatee

Manatee

Manatee

Manatee

Manatee

Manatee

Manatee

Manatee

Manatee

Manatee

Manatee

Manatee

Manatee

Manatee

Pinellas

Pinellas

Pinellas

Pinellas

Pinellas

Pinellas

Pinellas

Pinellas

Pinellas

Pinellas

Pinellas

Pinellas

Pinellas

Pinellas

Pinellas

Pinellas

Pinellas

Pinellas
9-76

$7-71$

$8-71$

$6-80$

$11-79$

$3-66$

$3-66$

5-66

$10-79$

$11-79$

$7-80$

4- 80

4- 80

$11-79$

$10-79$

$1-83$

$1-83$

$1-83$

$6-75$

4-76

$5-77$

$1-73$

$1-73$

$1-73$

$1-73$

$1-73$

$1-73$

$1-73$

$1-73$

$2-73$

$1-72$

$11-84$

$6-85$

2- 69

2-69

2-69

$6-67$

10- 66 


\begin{tabular}{|c|c|c|c|c|c|c|}
\hline \multicolumn{7}{|c|}{$\begin{array}{l}\text { Type of log and depth logged, } \\
\text { in feet below land-surface datum }\end{array}$} \\
\hline Electric & $\begin{array}{l}\text { Gamma- } \\
\text { ray }\end{array}$ & Caliper & $\begin{array}{c}\text { Fluid } \\
\text { conductivity }\end{array}$ & $\begin{array}{c}\text { Tempera- } \\
\text { ture }\end{array}$ & $\begin{array}{l}\text { Flow } \\
\text { meter }\end{array}$ & Other \\
\hline$\ldots$ & - - & 59 & $\ldots$ & - - & - - & - - \\
\hline 539 & 578 & - & -- & - - & - - & - \\
\hline 840 & 935 & 838 & - & - - & -- & - \\
\hline 46 & 130 & 74 & 525 & 92 & - & - \\
\hline 37 & 147 & 59 & 123 & 132 & -- & -- \\
\hline 262 & - & -- & 262 & - & - & $\ldots$ \\
\hline - - & - & - - & 470 & 470 & - & - \\
\hline 780 & - & - - & 780 & 780 & - - & - \\
\hline 36 & 148 & 49 & 131 & 142 & - & - \\
\hline 112 & 149 & 46 & 113 & 112 & -- & -- \\
\hline 542 & 556 & 555 & 499 & 499 & - - & - - \\
\hline 185 & 219 & 202 & - & - & - & - - \\
\hline 49 & - - & 21 & - & - & - & - - \\
\hline 101 & 247 & 190 & 208 & 228 & - & - \\
\hline 136 & 154 & 50 & - & - & - & -- \\
\hline 490 & 586 & 588 & - & 550 & - & - \\
\hline 335 & -- & 238 & - & -- & -- & - \\
\hline 449 & 449 & 450 & - - & 430 & - - & - - \\
\hline 816 & 780 & -- & - - & - - & - - & -- \\
\hline 720 & 856 & 760 & 805 & - & - & - \\
\hline 835 & 830 & 830 & - - & - & - & $\ldots$ \\
\hline 878 & 878 & 884 & - & - & -- & - - \\
\hline 134 & 134 & 134 & 134 & 134 & - - & - \\
\hline - - & 17 & $\ldots$ & -. & - . & - - & $\ldots$ \\
\hline-- & 17 & -- & - - & - & - & - \\
\hline- & 22 & - & - & - & - & -. \\
\hline - - & 47 & - - & $\ldots$ & - - & - - & - \\
\hline - & 46 & - - & - - & - - & - - & - \\
\hline - & 45 & - - & - - & - - & - - & - - \\
\hline- & 16 & - - & - & - & - & - - \\
\hline - - & 17 & - - & - - & - & - - & $\ldots$ \\
\hline 434 & 434 & - & 430 & 345 & - - & - - \\
\hline 130 & 188 & 130 & - - & - & - - & - \\
\hline - - & - - & 552 & - - & 552 & - - & - - \\
\hline 531 & 531 & 531 & 531 & -- & - & - \\
\hline - & 78 & - & - - & - & - & - - \\
\hline - - & 71 & - - & $\ldots$ & - - & - - & - \\
\hline - - & 66 & - - & - - & - - & - - & - - \\
\hline - - & 290 & - - & 246 & - - & - - & - - \\
\hline 172 & 229 & 192 & - - & - - & - & - - \\
\hline
\end{tabular}


We11 number

Local name

County

Date

275711082442801 275713082474001 275713082474101 275753082433701 275753082435301

275756082442801 275807082454802 275807082474502 275808082464802 275810082422501

275814082453101 275816082452301 275842082430301 275843082474201 275849082454601

275914082434102 275914082472002 275922082452002 275925082421002 275928082420701

275933082462302 275942082451601 280015082471201 280059082464902 280107082444902

280107082460402 280108082433802 280108082433901 280118082434501 280118082434501

280121082453901 280122082471101 280123082423401 280124082454601 280126082452301

280126082453301 280132082452801 280137082420301 280137082421401 280137082423401
City of Clearwater Well \#44 City of Clearwater Well \#21 City of Clearwater U.S. Geological Survey Holiday Inn

City of Clearwater We11 \#43 U.S. Geological Survey U.S. Geological Survey U.S. Geological Survey Biggins

City of Clearwater We11 \#32 \#50

City of Clearwater

City of Clearwater Pinellas 246

City of Clearwater We11 \#34

U.S. Geological Survey

U.S. Geologica1 Survey U.S. Geological Survey U.S. Geological Survey Town of Safety Harbor

U.S. Geological Survey E-11

City of Dunedin

U.S. Geological Survey U.S. Geological Survey

U.S. Geological Survey U.S. Geological Survey Florida Forest Service ROMP TR14-3

TR14-3

City of Dunedin \#14

H. P. Hood and Sons

U.S. Geological Survey City of Dunedin

City of Dunedin

City of Dunedin

TR14-2

U.S. Geological Survey

U.S. Geological Survey

U.S. Geological Survey
Pinellas

Pinellas

Pinellas

Pinellas

Pinellas

Pinellas

Pinellas

Pinellas

Pinellas

Pinellas

Pinellas

Pinellas

Pinellas

Pinellas

Pinellas

Pinellas

Pinellas

Pinellas

Pinellas

Pinellas

Pinellas

Pinellas

Pinellas

Pinellas

Pinellas

Pinellas

Pinellas

Pinellas

Pinellas

Pinellas

Pinellas

Pinellas

Pinellas

Pinellas

Pinellas

Pinellas

Pinellas

Pinellas

Pinellas

Pinellas
$10-66$

$10-66$

$5-67$

$2-67$

6-67

6-67

$2-69$

$1-69$

1-69

$7-67$

6-67

10-84

$5-72$

$10-66$

10-66

1- 69

1- 69

$1-69$

1-69

6-67

1- 69

10-84

7-67

$1-69$

1-69

$1-69$

1-69

6-67

12-84

$5-85$

$2-70$

7-67

$11-71$

$2-70$

$2-70$

$2-70$

10-84

$11-71$

11-71

11-71 


\begin{tabular}{|c|c|c|c|c|c|c|}
\hline \multicolumn{7}{|c|}{$\begin{array}{l}\text { Type of } \log \text { and depth logged, } \\
\text { in feet below land-surface datum }\end{array}$} \\
\hline Electric & $\begin{array}{c}\text { Gamma- } \\
\text { ray }\end{array}$ & Caliper & $\begin{array}{c}\text { Fluid } \\
\text { conductivity }\end{array}$ & $\begin{array}{c}\text { Tempera- } \\
\text { ture }\end{array}$ & $\begin{array}{l}\text { Flow } \\
\text { meter }\end{array}$ & Other \\
\hline $\begin{array}{l}184 \\
208 \\
281 \\
461 \\
119\end{array}$ & $\begin{array}{r}-- \\
275 \\
281 \\
544 \\
276\end{array}$ & $\begin{array}{r}184 \\
\ldots \\
281 \\
451 \\
-.\end{array}$ & $\begin{array}{r}220 \\
236 \\
-- \\
479 \\
232\end{array}$ & $\begin{array}{l}- \\
- \\
- \\
- \\
--\end{array}$ & $\begin{array}{l}- \\
\ldots \\
- \\
- \\
-\end{array}$ & $\begin{array}{l}-- \\
- \\
- \\
- \\
--\end{array}$ \\
\hline $\begin{array}{r}224 \\
\ldots \\
\cdots \\
- \\
115\end{array}$ & $\begin{array}{r}281 \\
92 \\
37 \\
41 \\
194\end{array}$ & $\begin{array}{r}288 \\
\ldots \\
\ldots \\
- \\
170\end{array}$ & $\begin{array}{c}260 \\
-- \\
-- \\
- \\
-\end{array}$ & $\begin{array}{l}- \\
- \\
- \\
-- \\
--\end{array}$ & $\begin{array}{l}- \\
\ldots \\
- \\
- \\
-\end{array}$ & $\begin{array}{l}- \\
- \\
- \\
- \\
-\end{array}$ \\
\hline $\begin{array}{r}213 \\
465 \\
338 \\
228 \\
--\end{array}$ & $\begin{array}{r}275 \\
-- \\
376 \\
203 \\
-.\end{array}$ & $\begin{array}{r}-- \\
465 \\
337 \\
-- \\
282\end{array}$ & $\begin{array}{r}217 \\
-- \\
338 \\
179 \\
227\end{array}$ & $\begin{array}{l}- \\
- \\
- \\
- \\
-\end{array}$ & $\begin{array}{l}- \\
- \\
- \\
- \\
-\end{array}$ & $\begin{array}{l}- \\
-- \\
-- \\
--\end{array}$ \\
\hline $\begin{array}{r}-- \\
-- \\
- \\
-- \\
180\end{array}$ & $\begin{array}{r}48 \\
30 \\
64 \\
69 \\
280\end{array}$ & $\begin{array}{l}- \\
-- \\
-- \\
-- \\
--\end{array}$ & $\begin{array}{c}\ldots \\
\ldots \\
- \\
\ldots \\
246\end{array}$ & $\begin{array}{l}- \\
- \\
- \\
- \\
-\end{array}$ & $\begin{array}{l}\ldots \\
\ldots \\
\ldots \\
\ldots \\
-\end{array}$ & $\begin{array}{l}- \\
- \\
-- \\
- \\
-\end{array}$ \\
\hline $\begin{array}{r}580 \\
90 \\
-- \\
--\end{array}$ & $\begin{array}{r}38 \\
580 \\
148 \\
70 \\
58\end{array}$ & $\begin{array}{l}- \\
- \\
90 \\
-- \\
--\end{array}$ & $\begin{array}{r}\ldots \\
\ldots \\
131 \\
\ldots \\
\ldots\end{array}$ & $\begin{array}{l}- \\
- \\
- \\
- \\
-\end{array}$ & $\begin{array}{l}- \\
- \\
- \\
- \\
-\end{array}$ & $\begin{array}{l}\ldots \\
- \\
- \\
\ldots \\
-\end{array}$ \\
\hline $\begin{array}{r}\cdots \\
\cdots \\
300 \\
325\end{array}$ & $\begin{array}{r}31 \\
80 \\
104 \\
303 \\
324\end{array}$ & $\begin{array}{c}-- \\
-- \\
-- \\
-- \\
325\end{array}$ & $\begin{array}{c}\ldots \\
\cdots \\
17 \\
-- \\
328\end{array}$ & $\begin{array}{c}\ldots \\
\ldots \\
\ldots \\
- \\
328\end{array}$ & $\begin{array}{l}- \\
- \\
-- \\
-- \\
--\end{array}$ & $\begin{array}{l}- \\
- \\
- \\
- \\
-\end{array}$ \\
\hline $\begin{array}{r}194 \\
200 \\
- \\
130 \\
104\end{array}$ & $\begin{array}{r}258 \\
256 \\
64 \\
190 \\
168\end{array}$ & $\begin{array}{r}190 \\
200 \\
-- \\
126 \\
104\end{array}$ & $\begin{array}{r}185 \\
\cdots \\
\cdots \\
- \\
116\end{array}$ & $\begin{array}{l}\ldots \\
- \\
- \\
- \\
-\end{array}$ & $\begin{array}{l}\ldots \\
\cdots \\
- \\
- \\
-\end{array}$ & $\begin{array}{l}- \\
- \\
- \\
- \\
-\end{array}$ \\
\hline $\begin{array}{l}152 \\
461\end{array}$ & $\begin{array}{l}220 \\
461\end{array}$ & $\begin{array}{l}152 \\
461\end{array}$ & $\begin{array}{l}170 \\
461\end{array}$ & $\overline{--}$ & $\begin{array}{l}-- \\
--\end{array}$ & $\begin{array}{ll}-- \\
-\end{array}$ \\
\hline $\begin{array}{l}- \\
-\end{array}$ & $\begin{array}{l}59 \\
50\end{array}$ & $\begin{array}{l}- \\
\cdots\end{array}$ & - & $\begin{array}{l}-- \\
--\end{array}$ & $\begin{array}{l}-- \\
-\end{array}$ & $\begin{array}{l}-- \\
-\end{array}$ \\
\hline - & 61 & $\ldots$ & - - & - & -- & -- \\
\hline
\end{tabular}


280143082424801

280152082463301

280202082423401

280228082465001

280251082453002

280254082441602

280254082441604

280254082463602

280320082455201

280345082422102

270518081593801

273559082251901

274518082011301

274547081420501

274547081470901

274547081470901

274759081590601

274805081595401

274805081595402

274807081595301

274807081595302

274807081595303

274810081592801

274814081594701

274814081594702

274819081592401

274819081594301

274819081594302

274820081594201

274820081594202

274821081590301

274821081591501

274821081594101

274823081590201

274826081593301

274826081593302

274827081592201

274827081593101

274827081593201

274827081593202
U.S. Geological Survey

City of Dunedin

U.S. Geological Survey

Oak Ridge Golf Course

U.S. Geological Survey

U.S. Geological Survey

U.S. Geological Survey

U.S. Geological Survey

Douglas Realty

U.S. Geological Survey

13-9

Heller Corporation

American Cyanamid Company

ROMP Well Site 45

ROMP 45-2

ROMP We11 Site 45

I.M.C.

U.S. Geological Survey

U.S. Geological Survey

U.S. Geological Survey

U.S. Geological Survey

U.S. Geological Survey

I.M.C.

U.S. Geological Survey

U.S. Geological Survey

I.M.C.

U.S. Geological Survey

U.S. Geological Survey

U.S. Geological Survey

U.S. Geological Survey

I.M.C.

I.M.C.

I.M.C.

I.M.C.

U.S. Geological Survey

U.S. Geological Survey

I.M.C.

I.M.C.

U.S. Geological Survey

U.S. Geological Survey
Pinellas

$11-71$

Pinellas

Pinellas

Pinellas

Pinellas

Pinellas

Pinellas

Pinellas

Pinellas

Pinellas

Polk

Polk

Polk

Polk

Polk

Polk

Polk

Polk

Polk

Polk

Polk

Polk

Polk

Polk

Polk

Polk

Polk

Polk

Polk

Polk

Polk

Polk

Polk

Polk

Polk

Polk

Polk

Polk

Polk

Polk
$7-67$

$11-71$

$8-77$

1-69

10-68

$1-69$

$1-69$

$7-67$

$1-69$

4-85

$6-75$

$8-70$

$1-78$

$2-78$

$5-75$

4-74

$8-73$

$8-73$

$8-73$

$8-73$

$8-73$

4-74

$8-73$

$8-73$

4-74

$8-73$

$8-73$

$8-73$

$8-73$

$6-75$

4-74

4-74

$6-74$

$8-73$

$8-73$

$8-73$

$6-74$

$8-73$

8-73 


\begin{tabular}{|c|c|c|c|c|c|c|}
\hline & & $\begin{array}{l}\text { Type of } \\
\text { in feet b }\end{array}$ & $\begin{array}{l}\text { og and depth } 1 \\
\text { ow land-surfac }\end{array}$ & $\begin{array}{l}\text { ged, } \\
\text { datum }\end{array}$ & & \\
\hline Electric & $\begin{array}{l}\text { Gamma- } \\
\text { ray }\end{array}$ & Caliper & $\begin{array}{c}\text { Fluid } \\
\text { conductivity }\end{array}$ & $\begin{array}{c}\text { Tempera- } \\
\text { ture }\end{array}$ & $\begin{array}{l}\text { Flow } \\
\text { meter }\end{array}$ & Other \\
\hline- & 56 & - & - & - & - & - \\
\hline- & 228 & 182 & - & -- & -- & -- \\
\hline- & 44 & - - & - & -- & -- & -- \\
\hline 168 & -- & -- & -- & -- & -- & -- \\
\hline-- & 27 & -- & -- & -- & -- & -- \\
\hline 329 & 386 & 350 & 330 & - & -- & - \\
\hline -. & 43 & $\ldots$ & $\ldots$ & - - & - - & - - \\
\hline-- & 18 & - & - & -- & - & - \\
\hline 110 & 190 & - & 155 & - & - & - \\
\hline$\cdots$ & 27 & -- & $\cdots$ & -- & -- & -- \\
\hline 709 & 709 & 709 & 709 & 709 & - & - \\
\hline 811 & 780 & - & - - & - - & -- & -- \\
\hline 1,242 & - - & 1,144 & 1,495 & 1,495 & -- & -- \\
\hline 319 & 320 & 320 & -- & 320 & -- & -- \\
\hline 680 & 753 & 680 & -- & 649 & -- & -- \\
\hline 182 & 182 & 182 & - & 182 & -- & - \\
\hline 295 & -- & $\ldots$ & - & 274 & -- & - \\
\hline- & 27 & - & -- & - - & - - & - \\
\hline - - & 22 & $\cdots$ & - & - & - - & -- \\
\hline-- & 36 & $\cdots$ & -- & -- & -- & -- \\
\hline - - & 22 & - & - & - & -- & -- \\
\hline- & 10 & - & - & -- & -- & -- \\
\hline 140 & - - & 174 & -- & -- & -- & $\mathrm{f}$ \\
\hline-- & 25 & -- & -- & -- & -- & -- \\
\hline-- & 16 & - & -- & -- & - & -- \\
\hline 127 & 185 & $\ldots$ & - & -- & - & $f$ \\
\hline - & 25 & $\ldots$ & - & - & $\cdots$ & -- \\
\hline$\cdots$ & 16 & - & - & - - & - - & - - \\
\hline$\ldots$ & 28 & $\ldots$ & - & - & - & - \\
\hline$\cdots$ & 25 & -- & -- & -- & -- & -- \\
\hline 176 & - & 176 & - & - & - & $\mathrm{f}$ \\
\hline 861 & - - & 168 & -- & - & - & $\mathrm{f}$ \\
\hline 81 & $\cdots$ & 114 & - - & - - & - & $f$ \\
\hline 184 & -- & 262 & -- & -- & -- & $f$ \\
\hline-- & 26 & -- & - - & - & -- & - - \\
\hline- & 16 & - & - & - & - & - \\
\hline 201 & 311 & 198 & -- & -- & - & -- \\
\hline 134 & -- & 152 & -- & - & -- & -- \\
\hline - - & 22 & - & -- & -- & -- & -- \\
\hline - - & 25 & - - & -- & -- & - - & - \\
\hline
\end{tabular}


274827081593203

274830081591501

274832081590401

274835081593601

274835081595501

274835081595502

274842082013801

274851082011201

274852082020801

274853082012601

274853082031801

274854082021201

274855082014501

274855082022501

274858082025501

274902082005701

274902082022101

274903082014201

274907082023201

274908082004201

274908082021101

274918082021401

274918082021401

274920082014501

274920082014502

274923082023601

274924082014101

274925081490201

274925081491301

274925082014501

274925082021401 274929081470301 274929081472701 274929081473901 274932081422601

275044081471002 275114081471002 275123081475102 275124081494201 275141081495201
U.S. Geological Survey

I.M.C.

I.M.C.

I.M.C.

U.S. Geological Survey

U.S. Geological Survey

I.M.C.

I.M.C.

I.M.C.

I.M.C.

I.M.C.

I.M.C.

I.M.C.

I.M.C.

I.M.C.

I.M.C.

I.M.C.

I.M.C.

I.M.C.

I.M.C.

I.M.C.

I.M.C.

I.M.C.

I.M.C.

I.M.C.

I.M.C.

I.M.C.

U.S. Geological Survey

U.S. Geological Survey

I.M.C.

Int. Min. Chem.

U.S. Geological Survey

U.S. Geological Survey

U.S. Geological Survey

I.M.C. Clear Springs Mine

I.M.C. Clear Springs Mine

I.M.C. Clear Springs Mine

I.M.C.

I.M.C.
Polk

Polk

Polk

Polk

Polk

Polk

Polk

Polk

Polk

Polk

Polk

Polk

Polk

Polk

Polk

Polk

Polk

Polk

Polk

Polk

Polk

Polk

Polk

Polk

Polk

Polk

Polk

Polk

Polk

Polk

Polk

Polk

Polk

Polk

Polk

Polk

Polk

Polk

Polk

Polk
$8-73$

$6-74$

$6-74$

$6-74$

8-73

$8-73$

$10-72$

$9-72$

$10-72$

$10-72$

$10-72$

$8-74$

2-74

$11-72$

$11-72$

9-72

$2-74$

10-72

$11-72$

10-72

9-72

$10-72$

$11-72$

9-72

$2-74$

11- 72

2- 74

8-73

$8-73$

9-72

$11-72$

$8-73$

$8-73$

8-73

3-76

$11-79$

12-79

11- 79

5- 74

5- 74 


\begin{tabular}{|c|c|c|c|c|c|c|}
\hline \multicolumn{7}{|c|}{$\begin{array}{l}\text { Type of } 1 \text { og and depth logged, } \\
\text { in feet below land-surface datum }\end{array}$} \\
\hline Electric & $\begin{array}{l}\text { Gamma- } \\
\text { ray }\end{array}$ & Caliper & $\begin{array}{c}\text { Fluid } \\
\text { conductivity }\end{array}$ & $\begin{array}{l}\text { Tempera- } \\
\text { ture }\end{array}$ & $\begin{array}{l}\text { Flow } \\
\text { meter }\end{array}$ & Other \\
\hline- & 16 & - & - & $\ldots$ & $\ldots$ & $\ldots$ \\
\hline 175 & 256 & 260 & - & $\cdots$ & $\ldots$ & $f$ \\
\hline 394 & - & 396 & - & $\ldots$ & $\ldots$ & $f$ \\
\hline 137 & - & 115 & - & - & $\ldots$ & $\mathrm{f}$ \\
\hline - & 27 & -- & - & - & - & - \\
\hline- & 15 & - & - & - & - & - \\
\hline 252 & -- & 250 & - - & - - & - - & $\mathrm{f}$ \\
\hline 207 & $\cdots$ & 205 & $\ldots$ & - & $\ldots$ & $\underline{I}$ \\
\hline 192 & - - & 190 & - - & - & - . & $f$ \\
\hline 184 & -- & 182 & - & - & - & $\mathrm{f}$ \\
\hline 200 & - & 197 & $\cdots$ & - & $\cdots$ & $\mathrm{f}$ \\
\hline 161 & -- & 177 & - & - - & $\ldots$ & $\mathrm{f}$ \\
\hline 186 & - - & 197 & - - & - - & $\ldots$ & $\mathrm{f}$ \\
\hline 124 & - & 122 & - & - & - & - \\
\hline 184 & -- & 182 & - & -- & - & $\mathrm{f}$ \\
\hline 208 & - & 205 & $\ldots$ & - & $\ldots$ & $\mathrm{f}$ \\
\hline 190 & - & 168 & $\cdots$ & - & $\ldots$ & $\mathrm{f}$ \\
\hline 211 & -- & 209 & $\cdots$ & - & $\ldots$ & $\mathrm{f}$ \\
\hline 199 & -- & 197 & - & - & $\ldots$ & $\mathrm{f}$ \\
\hline 248 & -- & 246 & -- & -- & -- & $\mathrm{f}$ \\
\hline 175 & - & 209 & -- & -- & $\ldots$ & $\ldots$ \\
\hline 221 & - - & 219 & $\cdots$ & - & - & $\mathrm{f}$ \\
\hline 221 & - - & 219 & - & - & - & - - \\
\hline 194 & - & 192 & - & - & -- & $\mathrm{f}$ \\
\hline 199 & - & 218 & $\cdots$ & - & - & $\mathrm{f}$ \\
\hline 326 & - & 314 & $\ldots$ & $\ldots$ & - & $\mathrm{f}$ \\
\hline 814 & - & 219 & $\ldots$ & - & - & $\mathrm{f}$ \\
\hline-- & 38 & -- & - & - & - - & $\cdots$ \\
\hline-- & 16 & -- & $\ldots$ & - & - & - \\
\hline 167 & - & 197 & -- & -- & - & $\mathrm{f}$ \\
\hline 475 & - & 453 & - & - & $\ldots$ & $\mathrm{f}$ \\
\hline - & 21 & -. & - & - & - - & - \\
\hline- & 56 & - & - & $\ldots$ & - - & - \\
\hline - & 36 & $\ldots$ & -. & $\ldots$ & - & - \\
\hline - - & - & 69 & -- & - & - & - \\
\hline 56 & 69 & 51 & 32 & 30 & - & - \\
\hline 35 & 69 & 41 & 39 & 51 & - & - \\
\hline- & 45 & 37 & - - & 37 & - - & - \\
\hline 187 & 222 & - & 140 & - & -. & $\ldots$ \\
\hline 47 & 91 & - & -. & $\ldots$ & - - & - - \\
\hline
\end{tabular}


275210081502501 275232081471302 275242081494401 275243081500601 275245081482801

275253081495201 275307081504001 275314081514201 275314081514201 275343081472303

275349081513801 275349081513801 275350081514201 275353081522401 275353081524501

275356081530401 275406081523703 275406081523703 275408081595701 275412081372101

275414081522603 275419081525803 275430082000401 275432081524303 275433081465501

275446081504003 275539081475601 280244081570801 280416081571901 280420081570701 280502081593701 280518081575801 280529081581102 280537081573802 280542081580302

280548081575701 280550081580401 280554081581001 280555081580303 280555081580306
I.M.C.

I.M.C. Clear Springs Mine

Farm Bureau

Chesterfield Smith

I.M.C.

Newe11

John Gibson

U.S. Geological Survey

ROMP 59

U.S. Geological Survey \& I.M.C.

Kuder Citrus Company

Kuder Citrus Company

Kuder Citrus Company

U.S.S. Agrichem

U.S.S. Agrichem

U.S.S. Agrichem

U.S. Steel

U.S.S. Agrichem

Kaiser Aluminum Company

ROMP 57

U.S. Steel

U.S. Steel

Kaiser Aluminum Company

U.S. Steel

Ed Thompson

U.S. Geological Survey

V. C. Corporation

City of Lakeland

City of Lakeland

City of Lakeland

$13-8$

City of Lakeland

Carpenter Home

Carpenter Home

Carpenter Home

Carpenter Home

Carpenter Home

Carpenter Home

Carpenter Home

Carpenter Home
Polk

$5-74$

Polk

Polk

Polk

Polk

Polk

Polk

Polk

Polk

Polk

Polk

Polk

Polk

Polk

Polk

Polk

Polk

Polk

Polk

Polk

Polk

Polk

Polk

Polk

Polk

Polk

Polk

Polk

Polk

Polk

Polk

Polk

Polk

Polk

Polk

Polk

Polk

Polk

Polk

Polk
$12-79$

$5-74$

$5-74$

5-74

$5-74$

5- 74

2-75

$1-77$

6- 80

10-69

10-69

$11-69$

$11-79$

6- 80

$11-79$

11- 79

$6-80$

4-76

$12-80$

$11-79$

$11-79$

$11-76$

$11-79$

3- 76

$6-80$

$2-71$

3- 68

3-69

2-69

4- 85

4- 68

$10-71$

$10-71$

$10-71$

$10-71$

$10-71$

$10-71$

$10-71$

10-71 


\begin{tabular}{|c|c|c|c|c|c|c|}
\hline \multicolumn{7}{|c|}{$\begin{array}{l}\text { Type of } 10 g \text { and depth logged, } \\
\text { in feet below land-surface datum }\end{array}$} \\
\hline Electric & $\begin{array}{l}\text { Gamma- } \\
\text { ray }\end{array}$ & Caliper & $\begin{array}{c}\text { Fluid } \\
\text { conductivity }\end{array}$ & $\begin{array}{l}\text { Tempera- } \\
\text { ture }\end{array}$ & $\begin{array}{l}\text { Flow } \\
\text { meter }\end{array}$ & Other \\
\hline 55 & 91 & 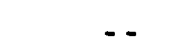 & - & $\ldots$ & - & $\cdots$ \\
\hline 37 & 166 & 53 & 26 & 40 & $\ldots$ & $\ldots$ \\
\hline 101 & 202 & $\ldots$ & $\ldots$ & 66 & $\ldots$ & $\ldots$ \\
\hline 67 & 119 & 83 & $\ldots$ & 60 & $\ldots$ & $\ldots$ \\
\hline 62 & 98 & - & - & $\cdots$ & -- & -- \\
\hline 117 & 117 & - & - - & 40 & $\ldots$ & $\ldots$ \\
\hline 67 & 119 & - & - - & 74 & - & $\cdots$ \\
\hline 1,223 & 1,412 & 1,234 & 389 & $\ldots$ & $\ldots$ & - \\
\hline 1,040 & - & 1,040 & 1,040 & - & - - & - - \\
\hline 73 & 90 & 30 & - & 40 & - & $\ldots$ \\
\hline 256 & - & 256 & 326 & 326 & - & $\ldots$ \\
\hline 256 & - & 256 & 326 & 326 & - & $\ldots$ \\
\hline 482 & 660 & 660 & 610 & 610 & $\ldots$ & - - \\
\hline 39 & 115 & 59 & 39 & 59 & $\ldots$ & $\ldots$ \\
\hline 535 & 677 & 672 & 585 & $\ldots$ & - & -- \\
\hline 74 & - & 72 & 37 & 59 & $\ldots$ & $\ldots$ \\
\hline 76 & $\cdots$ & 76 & - & 24 & - & -- \\
\hline 495 & 128 & 110 & 82 & $\ldots$ & - & $\ldots$ \\
\hline - - & 479 & 444 & - & 650 & $\ldots$ & $\mathrm{n}$ \\
\hline 620 & 634 & 620 & 620 & 634 & - & - \\
\hline 25 & 99 & 25 & 21 & 40 & - & - \\
\hline 43 & 112 & 56 & $\ldots$ & 56 & $\cdots$ & $\ldots$ \\
\hline- & 4,586 & 583 & $\ldots$ & 4,212 & $\ldots$ & $\mathrm{n}$ \\
\hline 32 & 96 & 42 & 22 & - & - & $\ldots$ \\
\hline 584 & 94 & 95 & - & - & 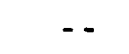 & $\cdots$ \\
\hline 51 & 78 & 52 & - - & 40 & $\ldots$ & $\ldots$ \\
\hline 584 & $\ldots$ & - & - & - & - & - \\
\hline 811 & 1,167 & 811 & 1,067 & - & - & $\ldots$ \\
\hline 451 & 636 & 636 & 550 & 550 & $\ldots$ & $\ldots$ \\
\hline 248 & 908 & 248 & 842 & 842 & $\ldots$ & $\ldots$ \\
\hline- & $\ldots$ & 440 & $\ldots$ & 440 & $\cdots$ & $\ldots$ \\
\hline 603 & -- & 603 & 739 & 739 & $\ldots$ & - - \\
\hline$\cdots$ & 19 & - & - & $\ldots$ & $\ldots$ & $\ldots$ \\
\hline-- & 17 & $\cdots$ & - & $\cdots$ & $\ldots$ & $\ldots$ \\
\hline- & 18 & $\cdots$ & - & - & $\ldots$ & $\ldots$ \\
\hline- & 22 & $\ldots$ & - & $\ldots$ & $\ldots$ & $\ldots$ \\
\hline$\ldots$ & 72 & - & $\ldots$ & $\ldots$ & $\ldots$ & - \\
\hline - & 37 & $\ldots$ & - - & - & - & - - \\
\hline$\ldots$ & 32 & - - & - - & $\ldots$ & - & - - \\
\hline- & 22 & - & - & - & - & $\ldots$ \\
\hline
\end{tabular}


Well number

Local name

County

Date

280559081580201 280559081582301 280604081575601 280723081485001 265527082213702

265531082194801 265627082205401 265645082195701 265653082190301 265702082201101

265710082205101 265712082205701 265714082195001 265731082201101 265757082202801

265801082205601 265808082201301 265808082202501 265809082194001 265810082195501

265816082193501 265819082195601 265820082192701 265823082194201 265826082194801

265826082201301 265828082192701 265828082195301 265833082200201 265834082200801

265834082202501 265927082112701 265928082205201 265937082241101 265944082175401

270015082240201 270018082201301 270018082210901 270019082213701 270021082221301
Carpenter Home

Carpenter Home

Carpenter Home

U.S. Geological Survey

Englewood Beach

SWFWMD TR3 - 3

Englewood Water District

Aldersgate Development

Englewood

Aldersgate Development

Englewood

Englewood

City of Englewood

Englewood Water District

Englewood Water District

George Plumberg

City of Englewood

City of Englewood

City of Englewood

City of Englewood

City of Englewood

City of Englewood

City of Englewood

City of Englewood

City of Englewood

City of Englewood

City of Englewood

City of Englewood

City of Englewood

City of Englewood

City of Englewood

Englewood Water District

21-468

Manasota Key

U.S. Geological Survey

01d Orange Grove near Englewood

Englewood Water District

Englewood Water District

Englewood Water District

Englewood
Polk

$10-71$

Polk

$10-71$

$10-71$

$10-74$

Polk

$8-72$

Sarasota

2-86

Sarasota

4-85

$7-72$

2-76

7-72

Sarasota

4-76

6-74

5-71

$6-78$

$6-74$

5-78

Sarasota

$5-71$

5-71

$5-71$

5-71

Sarasota

Sarasota

$5-71$

Sarasota

$5-71$

$5-71$

5-71

$5-71$

Sarasota

Sarasota

$\begin{array}{ll}\text { Sarasota } & 5-71 \\ \text { Sarasota } & 5-71\end{array}$

Sarasota $\quad 5-71$

Sarasota 5-71

Sarasota $\quad 5-71$

Sarasota $\quad 5-71$

Sarasota $\quad 6-74$

Sarasota 3-84

Sarasota $\quad 6-67$

Sarasota 5-66

Sarasota $\quad 8-84$

Sarasota 7-76

Sarasota $\quad 6-74$

Sarasota $\quad 6-74$

Sarasota $\quad 6-74$ 


\begin{tabular}{|c|c|c|c|c|c|c|}
\hline \multicolumn{7}{|c|}{$\begin{array}{l}\text { Type of log and depth logged, } \\
\text { in feet below land-surface datum }\end{array}$} \\
\hline Electric & $\begin{array}{l}\text { Gamma- } \\
\text { ray }\end{array}$ & Caliper & $\begin{array}{c}\text { Fluid } \\
\text { conductivity }\end{array}$ & $\begin{array}{c}\text { Tempera- } \\
\text { ture }\end{array}$ & $\begin{array}{l}\text { Flow } \\
\text { meter }\end{array}$ & Other \\
\hline$\cdots$ & 25 & - & - & - & -- & - \\
\hline - - & 18 & - & - & $\cdots$ & -- & -- \\
\hline-- & 10 & - & -- & -- & -- & -- \\
\hline 163 & - & - & -- & -- & -- & -- \\
\hline 312 & 312 & 312 & -- & -- & -- & -- \\
\hline$\cdots$ & 1,062 & - & - & -- & - & - \\
\hline 372 & 372 & 370 & - & - & - & -- \\
\hline - & 141 & - & - & - & - - & - \\
\hline 162 & 316 & 309 & - - & - - & - & - - \\
\hline 20 & 91 & 17 & - & -- & - & -- \\
\hline 256 & 293 & - & - & - & - & - \\
\hline 77 & 101 & 64 & - & - - & - & -- \\
\hline- & 42 & -- & -- & - - & - & - \\
\hline 104 & 148 & 114 & 131 & 138 & -- & -- \\
\hline 54 & 84 & -- & -- & -- & -- & -- \\
\hline- & 74 & - & - & -- & -- & - - \\
\hline- & 53 & - & -- & - & - - & - \\
\hline - & 44 & - & - & - - & - - & - - \\
\hline - - & 58 & - & - & - - & - - & - \\
\hline-- & 50 & -- & - & -- & -- & -- \\
\hline- & 43 & - & -- & - & - & -- \\
\hline- & 47 & -- & -- & -- & -- & - - \\
\hline-- & 47 & -- & - & -- & -- & -- \\
\hline-- & 44 & -- & - & -- & -- & -- \\
\hline-- & 43 & -- & -- & - - & - - & - - \\
\hline-- & 84 & - & - & -- & - & - \\
\hline - & 41 & - & $\cdots$ & $\cdots$ & -- & -- \\
\hline$\cdots$ & 45 & - & -- & - & - & -- \\
\hline- & 47 & - & - & - & - - & - - \\
\hline- & 43 & - & -- & -- & -- & -- \\
\hline- & 41 & - & - & -- & -- & -- \\
\hline 62 & 104 & 70 & - & -- & - - & - - \\
\hline-- & -- & 109 & - & 109 & - - & - - \\
\hline 260 & 260 & -- & -- & -- & -- & -- \\
\hline 77 & 105 & -- & -- & -- & -- & -- \\
\hline 234 & 286 & 266 & 250 & 285 & - & -- \\
\hline 79 & 112 & 96 & -- & -- & -- & -- \\
\hline 45 & 71 & 56 & - & - - & -- & - - \\
\hline 69 & 86 & 66 & $\cdots$ & -- & -- & -- \\
\hline 54 & 76 & 58 & - & -- & - - & $\cdots$ \\
\hline
\end{tabular}


270032082205801 270036082213401 270036082214101 270041082230401 270051082243201

270052082242601 270057082210501 270101082231201 270102082231901 270112082201201

270112082213301 270113082223301 270137082235301 270140082223601 270144082223301

270153082212601 270153082212601 270156082234401 270159082033101 270203082210101

270203082213701 270207082122301 270207082212301 270207082212401 270209082243201

270219082185801 270220082082101 270221082082001 270223082185701 270223082185801

270226082254301 270254082240101 270257082223201 270319082160601 270320082225001

270330082222901 270332082143801 270333082214301 270335082094801 270343082141901
Venetia Inc.

Englewood

Pete McE1murray

Dolphin Bath and Racquet Club

Mr. Turner

Jacob France

Venetia Inc.

Lester Fleming

Boldt

Englewood Water District

Englewood Water District

Englewood Water District

U.S. Geological Survey

Venetia Inc.

Venetia Inc.

Jack Berry

21-467

Englewood Disposal

General Development Corporation

Venetia Inc.

Venetia Inc.

General Development Corporation 21-461

$21-462$

Trautman

Manatee Junior College

General Development Corporation

General Development Corporation

Manatee Junior College

Manatee Junior College

City of Venice

Sarasota County

Venice Gardens Utilities

Diege1 Jackman

Venice East

Venice East

Jockey Club Entrance

Green Tree \#1

General Development Corporation

Jockey Recreation Club
Sarasota

4-81

Sarasota

$2-76$

Sarasota

$2-76$

Sarasota

$6-78$

Sarasota

$12-71$

Sarasota

$10-72$

Sarasota

Sarasota

Sarasota

Sarasota

Sarasota

Sarasota

Sarasota

Sarasota

Sarasota

Sarasota

Sarasota

Sarasota

Sarasota

Sarasota

Sarasota

Sarasota

Sarasota

Sarasota

Sarasota

Sarasota

Sarasota

Sarasota

Sarasota

Sarasota

Sarasota

Sarasota

Sarasota

Sarasota

Sarasota

Sarasota

Sarasota

Sarasota

Sarasota

Sarasota
4-81

$6-72$

$1-72$

7-76

$8-79$

$8-79$

$3-66$

$6-72$

6-72

$2-84$

$3-84$

$12-71$

$11-65$

5-72

5-72

$11-65$

2-84

$2-84$

4- 78

3- 84

$3-60$

$12-68$

3-84

3- 84

$11-73$

11- 65

$6-79$

$10-78$

$5-77$

$10-70$

$10-78$

$8-72$

$3-60$

$10-78$ 


\begin{tabular}{|c|c|c|c|c|c|c|}
\hline \multicolumn{7}{|c|}{$\begin{array}{l}\text { Type of log and depth logged, } \\
\text { in feet below land-surface datum }\end{array}$} \\
\hline Electric & $\begin{array}{l}\text { Gamma- } \\
\text { ray }\end{array}$ & Caliper & $\begin{array}{c}\text { Fluid } \\
\text { conductivity }\end{array}$ & $\begin{array}{c}\text { Tempera- } \\
\text { ture }\end{array}$ & $\begin{array}{l}\text { Flow } \\
\text { meter }\end{array}$ & Other \\
\hline 253 & 251 & 249 & 194 & $\ldots$ & - & - \\
\hline 48 & 62 & 63 & - & $\ldots$ & - & $\ldots$ \\
\hline 54 & 49 & 48 & - - & $\ldots$ & $\ldots$ & $\ldots$ \\
\hline 77 & 121 & 120 & - & $\ldots$ & $\ldots$ & $\ldots$ \\
\hline 127 & 174 & 124 & - & $\cdots$ & - & - \\
\hline 504 & 694 & 502 & $\ldots$ & $\ldots$ & $\ldots$ & $\ldots$ \\
\hline 190 & 183 & 186 & 165 & 180 & - . & - \\
\hline 24 & 67 & 22 & - - & - - & - & - \\
\hline 688 & 726 & 687 & $\ldots$ & $\ldots$ & - & $\ldots$ \\
\hline 58 & 115 & 58 & - & $\ldots$ & $\ldots$ & - \\
\hline$\ldots$ & 60 & 44 & $\ldots$ & $\ldots$ & $\ldots$ & $\ldots$ \\
\hline 121 & 146 & 99 & $\ldots$ & $\ldots$ & - & $\ldots$ \\
\hline 297 & 297 & - & 297 & $\ldots$ & $\ldots$ & - \\
\hline 263 & 463 & 261 & $\therefore$ & - & - & $\ldots$ \\
\hline 253 & - & 251 & - & - & - & $\cdots$ \\
\hline 213 & 251 & 251 & 251 & 606 & $\ldots$ & - \\
\hline 610 & 610 & 610 & 610 & 610 & - & - \\
\hline 627 & 627 & - & $\cdots$ & - & - & - \\
\hline 428 & - - & 360 & - & - & - & - - \\
\hline 103 & 309 & 102 & $\cdots$ & 311 & $\cdots$ & - \\
\hline 403 & 606 & 401 & - & $\ldots$ & $\ldots$ & $\ldots$ \\
\hline 74 & - & $\cdots$ & - & $\cdots$ & - & - \\
\hline$\ldots$ & $\ldots$ & 313 & 313 & 313 & $\ldots$ & - \\
\hline 600 & - & 600 & 600 & 600 & 600 & - \\
\hline- & 48 & - & - & - & $\cdots$ & -- \\
\hline 186 & 272 & 272 & 176 & 272 & -. & -. \\
\hline 628 & -- & $\cdots$ & $\cdots$ & - & - & $\cdots$ \\
\hline$\ldots$ & $\ldots$ & 628 & 628 & $\ldots$ & $\ldots$ & $\mathrm{f}$ \\
\hline 138 & 156 & 148 & 138 & 156 & $\ldots$ & $\ldots$ \\
\hline 119 & 207 & 193 & 124 & 114 & - & - \\
\hline 88 & $\ldots$ & 88 & 78 & $\ldots$ & - & - \\
\hline 142 & 142 & 142 & - & - & - & - \\
\hline 192 & 193 & 156 & - & $\cdots$ & - & $\cdots$ \\
\hline 65 & 79 & 78 & - & $\cdots$ & - & - \\
\hline- & 224 & 224 & - & 224 & - & $\cdots$ \\
\hline 726 & 726 & 726 & $\ldots$ & - & - & - \\
\hline 105 & 105 & 105 & - & -. & -. & $\ldots$ \\
\hline - . & 300 & 300 & - - & - & - & - \\
\hline 418 & -. & -. & - & $\ldots$ & - - & - \\
\hline 80 & 102 & 99 & 96 & - & - & - \\
\hline
\end{tabular}




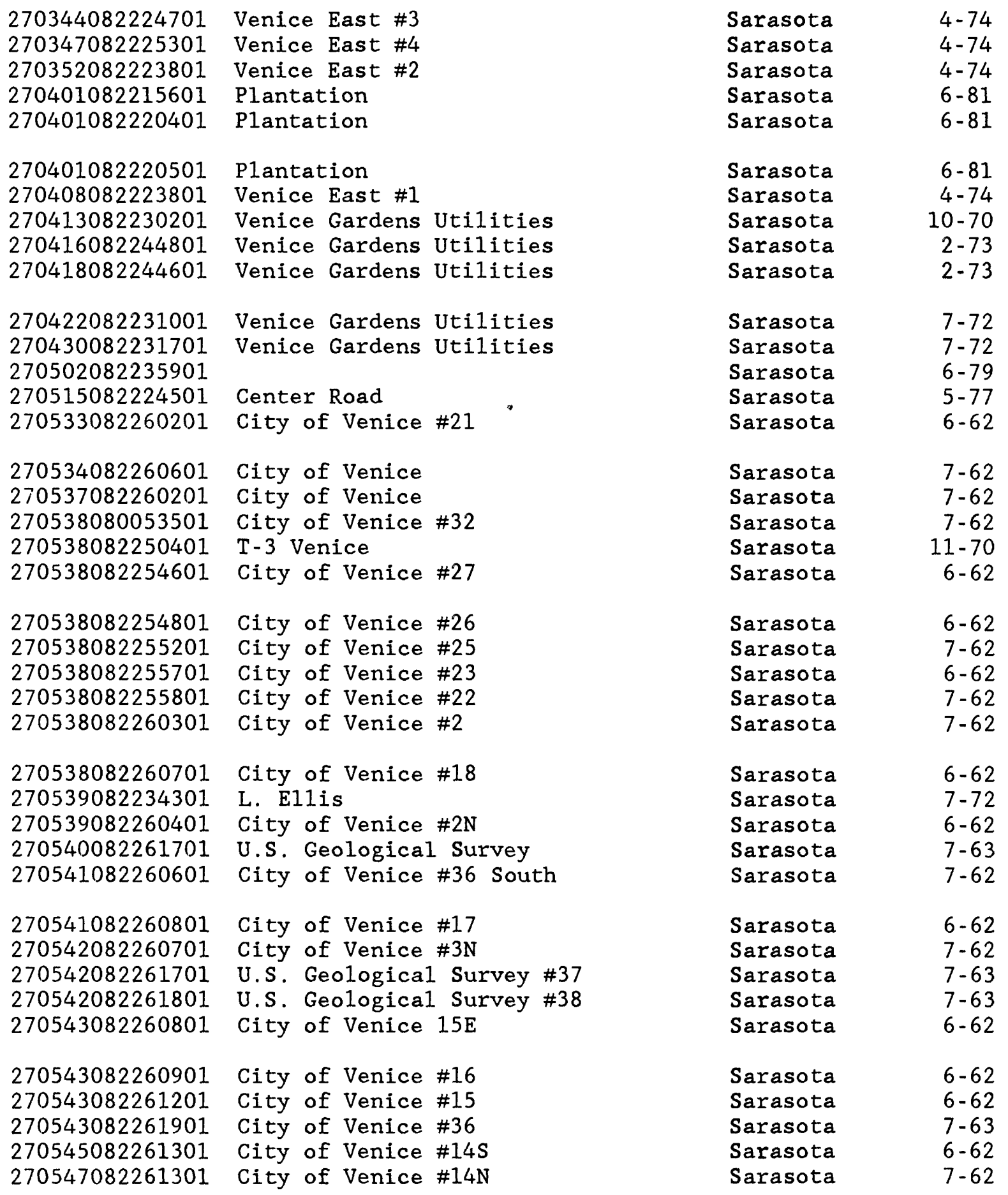




\begin{tabular}{|c|c|c|c|c|c|c|}
\hline \multicolumn{7}{|c|}{$\begin{array}{l}\text { Type of log and depth logged, } \\
\text { in feet below land-surface datum }\end{array}$} \\
\hline Electric & $\begin{array}{l}\text { Gamma- } \\
\text { ray }\end{array}$ & Caliper & $\begin{array}{c}\text { Fluid } \\
\text { conductivity }\end{array}$ & $\begin{array}{l}\text { Tempera- } \\
\text { ture }\end{array}$ & $\begin{array}{l}\text { Flow } \\
\text { meter }\end{array}$ & Other \\
\hline 724 & 724 & 722 & -- & - & - & -- \\
\hline 327 & 341 & 325 & - & $\cdots$ & $\cdots$ & -- \\
\hline 37 & -- & -- & - & - & - & -- \\
\hline 231 & 256 & 254 & 219 & - & - & $\mathrm{f}$ \\
\hline 215 & 250 & 242 & 215 & -- & -- & -- \\
\hline 168 & 171 & 156 & 136 & $\ldots$ & - & -- \\
\hline 217 & 214 & 214 & - & - & - & - \\
\hline 433 & 433 & - & - & - & - & - \\
\hline 85 & 141 & 82 & - - & - & - - & - - \\
\hline 73 & - & 71 & - & - & - & - \\
\hline 59 & 120 & 57 & - & - & - & $\ldots$ \\
\hline 52 & - - & 51 & -- & -- & -- & -- \\
\hline-- & 695 & $\cdots$ & $\cdots$ & -- & -- & -- \\
\hline-- & 218 & 220 & - & - & - & - \\
\hline 144 & 144 & -- & -- & -- & -- & - \\
\hline 66 & -- & - & - & - & - & - \\
\hline 92 & 92 & - & - - & - & - - & - - \\
\hline 59 & 60 & - & - & - - & - & - \\
\hline 136 & 136 & 136 & - & -. & - & - \\
\hline 118 & 118 & - & - & - & - & - \\
\hline 118 & 118 & - & - & - & -- & - \\
\hline 140 & 140 & -- & -- & -- & -- & -- \\
\hline 120 & 120 & -- & -- & -- & -- & -- \\
\hline 125 & 120 & -- & - & - & - & - \\
\hline 67 & -- & -- & -- & - & -- & -- \\
\hline 140 & 140 & - & - & - & - & - \\
\hline 34 & 93 & 32 & - & - - & - & -. \\
\hline 100 & 100 & - & - & - & - & - \\
\hline 22 & - - & - & - & - & - - & - \\
\hline 47 & -- & -- & -- & - & -- & -- \\
\hline 114 & 114 & $\cdots$ & $\cdots$ & - & - & - \\
\hline 109 & -- & - & -- & - & - & -- \\
\hline 43 & -- & - & -- & - & $\cdots$ & -- \\
\hline 163 & 163 & - & -- & -- & - & - \\
\hline 105 & 105 & -- & -- & - & -- & -- \\
\hline 111 & 111 & -- & - & - & - & - \\
\hline 98 & 98 & -- & -- & -- & -- & -- \\
\hline 68 & -- & -- & -- & -- & -- & $\cdots$ \\
\hline 124 & 124 & -- & -- & -- & - & - \\
\hline 109 & -- & - & -- & - & - - & - \\
\hline
\end{tabular}


270549082261501 270550082261601 270551082260801 270551082261601 270551082261801

270551082262201 270552082260901 270552082261701 270553082250301 270553082260801

270553082261101 270553082261201 270553082261701 270553082261801 270554082261201

270554082261801 270556082240301 270556082261207 270556082262401 270557082234601

270557082240601 270557082241001 270557082241401 270557082241701 270557082241801

270557082242201 270557082242301 270557082242301 270557082242801 270557082243301

270557082243701 270557082244201 270557082244601 270557082244601 270557082245001

270557082245401 270557082245801 270557082251201 270557082253801 270558082235301
City of Venice \#13S

City of Venice \#13N

City of Venice \#4N

City of Venice \#12S

City of Venice \#10

City of Venice \#9N

City of Venice \#5S

City of Venice \#12S

City of Venice \#38

City of Venice \#5

City of Venice \#5N

City of Venice \#6

City of Venice \#12N

City of Venice \#115

City of Venice \#75

City of Venice \#11N

Carl F. Kunze, Jr.

City of Venice \#7N

City of Venice

Jerome Elles

City of Venice \#6

City of Venice \#9

City of Venice \#8

City of Venice

City of Venice \#7

U.S. Geological Survey \#4

City of Venice \#5

City of Venice \#5S

City of Venice \#15

City of Venice \#14

City of Venice \#13

City of Venice \#16

City of Venice \#4

Venice Ranch

City of Venice \#12

City of Venice \#11

City of Venice \#10

City of Venice \#37

City of Venice \#1

Car1 F. Kunze \#58
Sarasota

$7-62$

Sarasota

Sarasota

Sarasota

Sarasota

Sarasota

Sarasota

Sarasota

Sarasota

Sarasota

Sarasota

Sarasota

Sarasota

Sarasota

Sarasota

Sarasota

Sarasota

Sarasota

Sarasota

Sarasota

Sarasota

Sarasota

Sarasota

Sarasota

Sarasota

Sarasota

Sarasota

Sarasota

Sarasota

Sarasota

Sarasota

Sarasota

Sarasota

Sarasota

Sarasota

Sarasota

Sarasota

Sarasota

Sarasota

Sarasota
$7-63$

$7-62$

$7-62$

6-62

7-62

$7-62$

$7-62$

$12-63$

$6-62$

$7-62$

$6-62$

$7-62$

6-62

7-62

7-62

$5-72$

7-62

1-74

$9-67$

7-71

7-71

7-71

7-71

7-71

$11-70$

$5-71$

5-71

7-71

7-71

$10-71$

$8-71$

$5-71$

11-84

7-81

7-71

7-71

$12-63$

5-71

5-72 


\begin{tabular}{|c|c|c|c|c|c|c|}
\hline \multicolumn{7}{|c|}{$\begin{array}{l}\text { Type of } 10 \mathrm{~g} \text { and depth logged, } \\
\text { in feet below land-surface datum }\end{array}$} \\
\hline Electric & $\begin{array}{l}\text { Gamma- } \\
\text { ray }\end{array}$ & Caliper & $\begin{array}{c}\text { Fluid } \\
\text { conductivity }\end{array}$ & $\begin{array}{l}\text { Tempera- } \\
\text { ture }\end{array}$ & $\begin{array}{l}\text { Flow } \\
\text { meter }\end{array}$ & Other \\
\hline 33 & - - & - & - & - & - & - \\
\hline 108 & - & - - & - & - - & - - & - - \\
\hline 110 & - - & - - & - - & - - & - - & - - \\
\hline 57 & - - & - - & - - & - - & -- & - - \\
\hline 113 & 113 & - & - & - & -- & -- \\
\hline 105 & - - & -- & -- & -- & - & -- \\
\hline 35 & -- & - - & - & - - & - - & - - \\
\hline 57 & - - & - - & - - & - - & - - & - - \\
\hline 99 & 99 & - - & - - & - - & - - & - - \\
\hline 114 & 114 & - & - & - & - & - \\
\hline 59 & -- & - & - & - & - & - \\
\hline 112 & 112 & - & - & - & -- & -- \\
\hline 108 & -- & - - & - & $\ldots$ & - & - \\
\hline 134 & 134 & -- & -- & - & -- & - \\
\hline 105 & -- & -- & -- & - - & -- & -- \\
\hline 104 & - & -- & - & -- & - & -- \\
\hline 317 & 347 & 347 & - - & - - & - - & - - \\
\hline 108 & - - & - - & - - & - - & - - & - - \\
\hline 66 & 264 & 84 & - & - & - & - \\
\hline 390 & 390 & 390 & - & - & - & - \\
\hline - - & 104 & 24 & - - & - - & - - & - - \\
\hline - - & 104 & 33 & - - & - - & - - & - - \\
\hline 85 & 143 & 85 & - - & - & - - & - - \\
\hline 58 & 125 & 54 & - - & - - & -- & - \\
\hline 58 & 125 & 54 & - & - & - & - \\
\hline 129 & 129 & 129 & - & - & - - & - \\
\hline - - & 140 & 87 & - - & - - & - - & - - \\
\hline-- & 140 & 87 & - - & - - & - - & - - \\
\hline 78 & 141 & 77 & - & - - & - - & - - \\
\hline 74 & 140 & 76 & -- & -- & - - & -- \\
\hline 140 & 140 & 61 & -- & - & - & - \\
\hline 68 & 140 & 67 & - & -- & -- & -- \\
\hline 49 & 120 & 50 & - & - & - & - \\
\hline - - & -- & 396 & -- & 396 & -- & -- \\
\hline 67 & 143 & 67 & -- & -- & - - & -- \\
\hline 105 & 183 & 106 & - & - & - - & - \\
\hline 98 & 142 & 116 & -- & - & -- & -- \\
\hline 129 & 129 & - - & - & - & - & - \\
\hline 84 & 132 & 133 & - & - & - & - \\
\hline 322 & 397 & 317 & -- & - & - & -- \\
\hline
\end{tabular}


We11 number

Loca1 name

County

Date

270558082251801

City of Venice \#36

Sarasota

$12-63$

270558082252301

City of Venice \#35

Sarasota

$12-63$

270558082253201

City of Venice \#34

270558082253701

City of Venice \#33

Sarasota

$12-63$

270558082261901

City of Venice \#9N

Sarasota

$7-62$

Sarasota

$7-62$

270600082222001 Moore Well

Sarasota

$6-77$

Cross-U-Trails

Sarasota

$6-77$

Cleaver's We11

270600082232001

270602082260301

W.C.I.N.D.

270602082260501

Blackburn Quarters

Sarasota

$6-77$

Sarasota

$7-65$

Sarasota

$6-72$

270602082261501

270603082250301

270603082261701

Artesian Well

City of Venice

Sarasota

$6-62$

Artesian Well

270607082225001

Elephant Barn We11

Sarasota

$12-63$

Sarasota

$6-62$

270607082262801

City of Venice

$12-63$

Sarasota

$1-74$

270608082240201

270608082245801

270609082254501

270610082225601

$\# 40$

$\# 42$

270611082260101

Ridgewood Mobile Home Park

Constantine

City of Venice

Sarasota

$\begin{array}{ll}\text { Sarasota } & 12-63 \\ \text { Sarasota } & 12-63\end{array}$

Sarasota

$9-68$

Sarasota

$6-79$

Sarasota

2-83

270613082240201

270613082245001

City of Venice \#41

City of Venice \#52

270613082252301

270618082244701

270620082214701

U.S. Geological Survey $\mathrm{T} / \mathrm{W} \# 2$

Capri Isles

Venice

Sarasota

$12-63$

Sarasota

$2-69$

Sarasota

$11-70$

Sarasota

$7-71$

Sarasota

$7-78$

270622082254101

270622082254101

270630082231801

270630082233701

270640082235601

Bay Indies Park

Sarasota

$11-72$

Bay Indies Park

George Woods

George Woods

Tennis Club

270640082240201

270641082245501

270642082253801

270650082260101

270654082222001

George Woods

U.S. Geological Survey $\mathrm{T} / \mathrm{W} \# 1$

Bay Indies P-2

Sarasota

$11-72$

Sarasota

$10-63$

Sarasota

$10-63$

Sarasota

$6-79$

Venice By-Way Well

Pond Well near Everglade Estate

270657082270401

J. Biller

270659082233901

Fox Lee Farms

270705082204001

$21-463$

270705082222201

High Point Road We11

Sarasota

$10-63$

Sarasota

$10-70$

Sarasota

$9-74$

Sarasota

$10-63$

Sarasota

$8-84$

Sarasota

$7-77$

Sarasota

$8-84$

Sarasota

$2-84$

Sarasota

$8-80$

Sarasota

7-63 


\begin{tabular}{|c|c|c|c|c|c|c|}
\hline \multicolumn{7}{|c|}{$\begin{array}{l}\text { Type of log and depth logged, } \\
\text { in feet below land-surface datum }\end{array}$} \\
\hline Electric & $\begin{array}{l}\text { Gamma- } \\
\text { ray }\end{array}$ & Caliper & $\begin{array}{c}\text { Fluid } \\
\text { conductivity }\end{array}$ & $\begin{array}{c}\text { Tempera- } \\
\text { ture }\end{array}$ & $\begin{array}{l}\text { Flow } \\
\text { meter }\end{array}$ & Other \\
\hline 50 & 50 & 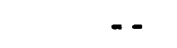 & - & - & $\cdots$ & - \\
\hline 128 & 128 & - & - & - & -- & -- \\
\hline 99 & 99 & - & - & $\cdots$ & - & -- \\
\hline 131 & 131 & - & - & - & -- & - \\
\hline 105 & - & - & - & - & - & -- \\
\hline- & 377 & 378 & - & 378 & $\cdots$ & - \\
\hline- & 421 & 421 & $\cdots$ & 422 & - & - \\
\hline$\cdots$ & 261 & 262 & - & 262 & - & -- \\
\hline 453 & 125 & - - & -- & - - & - & - \\
\hline 414 & 410 & - & -- & -- & -- & -- \\
\hline 124 & 124 & $\ldots$ & - & $\ldots$ & - & $\ldots$ \\
\hline 115 & 115 & - - & - & - & - & -- \\
\hline 304 & 300 & 382 & -. & $\ldots$ & - & -- \\
\hline 429 & 429 & - & -- & - & -- & - \\
\hline 266 & 264 & 264 & -- & - & - & -- \\
\hline 128 & 128 & - & - & - & -. & -- \\
\hline 130 & 130 & - & - & - - & -- & - \\
\hline 380 & 380 & - & 380 & - - & - & $\mathrm{f}$ \\
\hline 384 & 385 & 369 & 379 & 379 & -- & -- \\
\hline 328 & 336 & 338 & - - & -. & - & -- \\
\hline 130 & 130 & - & $\ldots$ & - & - & -- \\
\hline 127 & 127 & 127 & 127 & 127 & - & $f$ \\
\hline 110 & 110 & 110 & - & - & -. & - \\
\hline- & 256 & -. & - & - & - & -- \\
\hline 342 & 352 & 352 & 357 & - & - & $\cdots$ \\
\hline 49 & 241 & 47 & - & - - & - & $\ldots$ \\
\hline 49 & 241 & 47 & - & - & - - & -- \\
\hline 281 & 281 & - & - & - - & - - & - \\
\hline 307 & 307 & -- & - - & - - & - - & -- \\
\hline-- & $\cdots$ & 382 & - & -- & - - & -- \\
\hline 401 & 401 & - - & - - & - - & - - & - - \\
\hline 204 & 204 & - & - - & - - & - & - \\
\hline 670 & 670 & - - & - - & - & - & - \\
\hline 381 & 381 & - & - - & - & - & -. \\
\hline 424 & 460 & 454 & 445 & 456 & - & -- \\
\hline 442 & 442 & - & - & 443 & -. & - \\
\hline - - & 186 & 186 & 178 & 188 & -- & -- \\
\hline 472 & - - & 472 & 472 & 472 & -- & - - \\
\hline 303 & 356 & 356 & 319 & 356 & - & $\cdots$ \\
\hline 245 & 245 & - - & - - & - - & - - & -- \\
\hline
\end{tabular}


270718082155201 270731082271401 270731082341401 270732082271201 270757082270101

270808082270801 270815082221201 270815082235001 270822082231101 270839082274201

270839082274301 270840082225101 270846082274301 270904082281701 270919082234201

270931082255901 270932082283501 270946082282301 270952082095901 270959082203001

270959082203001 271002082283301 271005082195001 271007082283901 271021082151601

271021082151601 271037082075401 271052082175601 271108082100301 271117082074001

271118082082401 271118082285301 271122082074601 271127082094401 271130082064901

271135082280101 271137082074802 271137082074802 271137082074802 271138082074801
U.S. Geological Survey

Sarasota

Sarasota

Sarasota

Sarasota

Sarasota

Sarasota

Sarasota

Henry Ranch

Stephen T. Deans

Virginia Burket (Henry Ranch)

Spanish Lake

Spanish Lake

Henry Ranch

Spanish Lake

Renata Barbarigo

TR5 - 2

Ewing Ranch Well

Sorrento Shores

Sorrento Shores

Mabry Carlton

MacArthur Tract

ROMP 19

Sorrento Shores

MacArthur Tract

State of Florida

MacArthur Tract

ROMP 19x

Mabry Carlton

MacArthur Tract

Mabry Carlton

Mabry Carlton

Mabry Carlton

U.S. Geological Survey

Mabry Carlton

Mabry Carlton

Mabry Carlton

Rib Walker

SWFWMD

ROMP 18-1

SWFWMD ROMP 18-2

Mabry Carlton
Sarasota

Sarasota

Sarasota

Sarasota

Sarasota

Sarasota

Sarasota

Sarasota

Sarasota

Sarasota

Sarasota

Sarasota

Sarasota

Sarasota

Sarasota

Sarasota

Sarasota

Sarasota

Sarasota

Sarasota

Sarasota

Sarasota

Sarasota

Sarasota

Sarasota

Sarasota

Sarasota

Sarasota

Sarasota

Sarasota

Sarasota

Sarasota
Sarasota
5- 66

7-63

$7-63$

7-63

4-78

3- 82

4-81

4-81

4-81

4-74

4- 74

4-81

4- 74

4-78

$6-84$

8- 84

$11-85$

$12-71$

$2-81$

$10-80$

10-80

$12-71$

7-80

$7-79$

6- 80

$8-80$

2-81

$6-85$

2-81

$2-81$

2-81

1-66

5-79

5-66

10-78

$6-65$

10-80

$7-79$

12-80

5-79 
Type of $\log$ and depth logged, in feet below land-surface datum

\begin{tabular}{|c|c|c|c|c|c|c|}
\hline Electric & $\begin{array}{l}\text { Gamma- } \\
\text { ray }\end{array}$ & Caliper & $\begin{array}{c}\text { Fluid } \\
\text { conductivity }\end{array}$ & $\begin{array}{c}\text { Tempera- } \\
\text { ture }\end{array}$ & $\begin{array}{l}\text { Flow } \\
\text { meter }\end{array}$ & Other \\
\hline 87 & 342 & 84 & - - & - - & - - & - \\
\hline 480 & 480 & - - & - - & - - & - & $\ldots$ \\
\hline 480 & 480 & - & - - & - & - & - \\
\hline 238 & 238 & -- & -- & - & - & - \\
\hline 53 & 73 & 78 & 86 & - & -- & -- \\
\hline 629 & 649 & 282 & 553 & - & -- & - \\
\hline 166 & 166 & 168 & - & - - & - - & - \\
\hline 353 & 357 & 357 & 343 & $\cdots$ & - & - \\
\hline 282 & 282 & 281 & 266 & - & - & - \\
\hline 168 & -- & -- & -- & -- & -- & -- \\
\hline 88 & 90 & 50 & - & $\ldots$ & -. & - \\
\hline 58 & 72 & 74 & - & -. & -. & - \\
\hline 209 & 222 & 221 & - & -. & - & - \\
\hline 126 & 117 & 95 & -- & -- & -- & -- \\
\hline-- & - & - & -- & -- & -- & -- \\
\hline 231 & 252 & 249 & 226 & 252 & - & - \\
\hline 659 & 665 & 632 & 599 & - & - - & - \\
\hline 65 & 235 & 65 & - - & - & - & - \\
\hline 225 & 227 & 276 & 262 & - & - & - \\
\hline 356 & 418 & 391 & 342 & 362 & -- & $\mathrm{f}$ \\
\hline 356 & - & - & - & - & -- & $\mathrm{f}$ \\
\hline 79 & 333 & 79 & -. & - & - & - - \\
\hline 83 & - & 78 & - & - & - & - \\
\hline 337 & - & 155 & - & -. & - & - \\
\hline 348 & 415 & 69 & 359 & 359 & - & $\mathrm{f}$ \\
\hline 389 & - & - & - & - & $\ldots$ & $\mathrm{f}$ \\
\hline 1,288 & 1,354 & 1,356 & 1,298 & 1,298 & -- & -- \\
\hline 360 & 397 & 400 & 256 & - & - & - - \\
\hline 422 & 445 & 446 & 418 & - - & -- & -- \\
\hline 543 & 569 & 569 & 532 & - & -- & -- \\
\hline 286 & 296 & 297 & -- & -- & -- & -- \\
\hline 151 & - - & - - & -- & - & - - & - - \\
\hline 230 & 285 & 255 & 267 & - & - - & -- \\
\hline 422 & 422 & 422 & 422 & - & - - & - - \\
\hline 400 & 447 & 460 & 400 & 400 & -- & - \\
\hline 720 & - & - & - & - & $\ldots$ & - - \\
\hline - - & - & - & 420 & - & - & - \\
\hline 940 & 940 & 910 & 910 & 910 & -- & - \\
\hline - & 820 & - & 420 & - & - & -- \\
\hline 21.3 & 246 & 221 & 228 & -- & -- & -- \\
\hline
\end{tabular}


271207082075201 271208082284901 271211082102601 271212082290801 271218082081801

271222082042301 271222082295201 271225082295301 271226082105301 271226082294601

271227082084801 271227082103001 271328082210701 271329082205601 271348082221801

271351082301701 271353082295701 271416082284301 271420082225701 271428082305301

271456082230901 271514082302401 271520082320001 271524082272801 271524082321201

271525082272801 271527082301701 271544082290801 271547082290301 271550082320501

271601082325901 271601082330201 271603082323101 271608082280201 271609082252401

271609082324501 271610082323301 271613082300201 271614082304201 271614082304301
Mabry Carlton

Palmer Corporation

Mabry Carlton

Palmer Corporation

Mabry Carlton

Cecil Daughtrey

Sarasota Historical Society

Oaks Property

Mabry Carlton

Oaks Property

Mabry Carlton

Mabry Carlton

Buck Hawkins

State of Florida

Buck Hawkins

Eide

Will Banks

Palmer Corporation

Buck Hawkins

Lowell Selders

U.S. Geological Survey

Gulf Gate Golf Course

Siesta Key

Sunrise Golf Course

Ray Littre11

Sunrise Utilities

Gulf Gate Corporation

Palmer Corporation

Palmer Corporation

Guest-Meadowood Street

TR6 - 1

TR6 - 1

Gulf and Bay Club, Siesta Key

U.S. Geological Survey

Jim Mosbey

Royal Palms Harbor

Boatyard

Earl Beach

John Thode
Sarasota

$2-81$

Sarasota

Sarasota

Sarasota

Sarasota

Sarasota

Sarasota

Sarasota

Sarasota

Sarasota

Sarasota

Sarasota

Sarasota

Sarasota

Sarasota

Sarasota

Sarasota

Sarasota

Sarasota

Sarasota

Sarasota

Sarasota

Sarasota

Sarasota

Sarasota

Sarasota

Sarasota

Sarasota

Sarasota

Sarasota

Sarasota

Sarasota

Sarasota

Sarasota

Sarasota

Sarasota

Sarasota

Sarasota

Sarasota

Sarasota
$2-88$

2- 81

$2-82$

$3-81$

$5-72$

2-82

$2-82$

$2-81$

$2-82$

$3-81$

2- -81

$5-66$

$7-73$

5-66

1- 82

$11-73$

4-74

5-66

4-78

$2-66$

4-65

$5-77$

3-84

$7-63$

5- 83

$5-65$

4-74

4- 74

$12-78$

$10-78$

$12-78$

$7-63$

8- 66

$10-78$

$6-74$

4- 62

7-64

$12-63$

8- 84 


\begin{tabular}{|c|c|c|c|c|c|c|}
\hline \multicolumn{7}{|c|}{$\begin{array}{l}\text { Type of log and depth logged, } \\
\text { in feet below land-surface datum }\end{array}$} \\
\hline Electric & $\begin{array}{l}\text { Gamma - } \\
\text { ray }\end{array}$ & Caliper & $\begin{array}{c}\text { Fluid } \\
\text { conductivity }\end{array}$ & $\begin{array}{c}\text { Tempera- } \\
\text { ture }\end{array}$ & $\begin{array}{l}\text { Flow } \\
\text { meter }\end{array}$ & Other \\
\hline 256 & 283 & 283 & 266 & - & -. & -. \\
\hline 239 & 241 & 240 & -. & -. & - & -. \\
\hline 760 & 652 & 644 & 620 & -. & -. & -. \\
\hline 430 & 492 & 491 & - & - & .. & -. \\
\hline 242 & 369 & 252 & 252 & - & - & $\cdots$ \\
\hline 1,319 & - & - & - & $\ldots$ & - & - \\
\hline 224 & 213 & 213 & - & - & - & - \\
\hline 73 & - & - & - & - & - - & - \\
\hline 510 & 569 & 565 & 512 & - & - & $\cdots$ \\
\hline 614 & 615 & 614 & 598 & $\cdots$ & $\cdots$ & -. \\
\hline 340 & 364 & 365 & 328 & $\cdots$ & - & $\cdots$ \\
\hline 814 & 866 & 867 & 810 & -. & -. & - \\
\hline 69 & 105 & -. & - & -. & -. & - \\
\hline 576 & 600 & -. & -. & $\ldots$ & - & - \\
\hline 134 & 182 & - & - & $\cdots$ & - & $\cdots$ \\
\hline 139 & - & 152 & - & - & - & - \\
\hline 357 & 267 & 367 & - & - & - & - \\
\hline 110 & 127 & $\cdots$ & $\cdots$ & $\cdots$ & - & - \\
\hline 880 & 880 & -. & -. & -. & - & - - \\
\hline 44 & 72 & 64 & 67 & $\cdots$ & $\cdots$ & $\cdots$ \\
\hline 47 & - & -. & - & - & -. & - \\
\hline 644 & - & -. & - & - & -. & - \\
\hline - & 391 & 391 & - & 391 & -. & - \\
\hline 333 & 451 & 372 & 413 & 447 & -- & - \\
\hline 418 & 418 & - & - & - & - & $\cdots$ \\
\hline 301 & 306 & 306 & - & - & - & - \\
\hline 499 & -. & -. & - & -. & -. & -. \\
\hline 303 & - & - & - & - & -. & -. \\
\hline 358 & 418 & 318 & - & -. & -. & -. \\
\hline 61 & 97 & - & $\cdots$ & - & $\cdots$ & - \\
\hline 561 & 561 & 542 & - & -. & -. & -. \\
\hline -. & 307 & $\ldots$ & -. & -. & -. & -. \\
\hline 262 & 262 & $\cdots$ & $\cdots$ & $\cdots$ & $\cdots$ & $\cdots$ \\
\hline 44 & 98 & 38 & - & $\ldots$ & -. & -. \\
\hline 111 & 145 & 138 & 128 & $\cdots$ & - & $\cdots$ \\
\hline 278 & 335 & 278 & 316 & -. & -. & - \\
\hline 515 & 515 & - & $\cdots$ & $\cdots$ & -- & - - \\
\hline 601 & 601 & - & - & $\cdots$ & - & $\cdots$ \\
\hline 705 & 705 & - & $\cdots$ & - & $\cdots$ & $\cdots$ \\
\hline - & - & 684 & - & $\cdots$ & - - & -- \\
\hline
\end{tabular}


271619082334101

271620082233001

271620082334901

271623082314201

271623082335601

271624082314801

271624082333801

271625082325501

271633082330401

271636082330201

271642082292901

271642082330601

271644082330001

271649082270701

271649082271601

271649082271602

271654082331101

271659082313001

271709082295401

271714082321901

271728082274201

271737082314601

271743082281901

271744082290301

271747082320401

271749082285901

271751082305401

271753082272301

271757082241301

271803082163701

271803082284101

271806082313801

271808082341401

271809082341501

271816082159901

271824082283601

271830082294801

271837082281401

271845082304301

271846082250901
Travel By the Sea

Florida Cities Utilities

B. P. George

Bill Chapman

Terrence Towers

Novak Realty Company

Archibald Water System

Siesta Key School

S.K.U.A.

S.U.K.A.

Arapaho

Siesta Isles Water System

Hidden Harbor Association

Albritton Groups, Inc.

Albritton Groups, Inc.

Albritton Groups, Inc.

Sarasota County

Phillip Anderson

21-1004

Dunhill Property

Chill Plaza

Ivey Taylor

Strathmore Villa

Thompson-Hinson

Southeast P1aza

Thompson-Lisbon

Dunnhil1 Property

U.S. Geological Survey

O. F. Smith Ranch

Busti Drive

Sarasota Board of Education

Key Towers

Ledo Towers

Flying S Ranch

Guest-Avert Avenue

Phillips Petroleum

Egological Utilities

Morrison

Sarasota Golf Club (private)
Sarasota

$12-74$

Sarasota

$1-68$

Sarasota

$10-68$

Sarasota

$8-63$

Sarasota

3-71

Sarasota

$8-63$

Sarasota

$7-63$

Sarasota

Sarasota

$10-64$

$7-80$

Sarasota

$7-80$

Sarasota

$12-74$

Sarasota

$12-63$

Sarasota

$8-72$

Sarasota

$11-81$

Sarasota

$11-81$

Sarasota

1-82

Sarasota

Sarasota

Sarasota

$5-71$

5-66

7-63

Sarasota

3-85

Sarasota

$11-72$

Sarasota

$12-85$

Sarasota

Sarasota

$5-71$

Sarasota

$11-78$

Sarasota

$5-65$

Sarasota

Sarasota

Sarasota

Sarasota

11-78

$11-72$

7-66

4-65

Sarasota

7-78

Sarasota

Sarasota

Sarasota

Sarasota

$12-63$

$5-72$

1-68

5-62

Sarasota

7-78

Sarasota

7-63

Sarasota

9-72

Sarasota

$10-83$

Sarasota

7-78 


\begin{tabular}{|c|c|c|c|c|c|c|}
\hline \multicolumn{7}{|c|}{$\begin{array}{l}\text { Type of } \log \text { and depth logged, } \\
\text { in feet below land-surface datum }\end{array}$} \\
\hline Electric & $\begin{array}{l}\text { Gamma- } \\
\text { ray }\end{array}$ & Caliper & $\begin{array}{c}\text { Fluid } \\
\text { conductivity }\end{array}$ & $\begin{array}{c}\text { Tempera- } \\
\text { ture }\end{array}$ & $\begin{array}{l}\text { Flow } \\
\text { meter }\end{array}$ & Other \\
\hline 306 & 306 & 306 & - & - & - & - \\
\hline 380 & 380 & 380 & - & $\ldots$ & - & - \\
\hline 194 & - - & - - & -- & - - & - - & - - \\
\hline 314 & 314 & - & - & - & - - & - \\
\hline 1,338 & 1,338 & -- & 1,338 & -- & - - & -- \\
\hline 230 & 230 & - & - & -- & - & - \\
\hline 151 & 151 & - & -- & - - & - - & - - \\
\hline 292 & 292 & - & - & - & - & - \\
\hline 244 & 466 & 449 & - & $\ldots$ & - & -- \\
\hline 473 & 475 & 478 & - & - & - & -- \\
\hline 563 & 563 & 563 & - & -- & - & - \\
\hline 233 & 233 & -. & - & -. & -. & -. \\
\hline 238 & 317 & 236 & - & - & - & - \\
\hline 232 & 270 & 266 & - & -- & - - & - \\
\hline 670 & 698 & 698 & -- & -- & - & - \\
\hline 521 & 795 & 561 & 529 & - & - & - - \\
\hline 165 & 406 & 162 & - - & - - & - - & - - \\
\hline 336 & 736 & - - & - - & - - & - - & - - \\
\hline 484 & 432 & - & - & - & - & - \\
\hline 598 & 598 & 598 & 598 & 598 & - & - \\
\hline 45 & 145 & 41 & - & - & - & $\ldots$ \\
\hline 109 & - & 159 & - & - & - . & - \\
\hline 646 & -- & 646 & 646 & - & $\ldots$ & - \\
\hline 336 & - & - & - & - & - - & - \\
\hline 122 & 155 & 117 & 135 & - & - & $\cdots$ \\
\hline 368 & - & - & $\ldots$ & $\ldots$ & $\ldots$ & - \\
\hline 52 & 52 & 48 & - - & - - & - - & - - \\
\hline 30 & 101 & 26 & - & - - & - - & - - \\
\hline- & - & -- & - & - & - & - \\
\hline 819 & - - & - - & -- & - & - & - \\
\hline- & 120 & 100 & - - & 76 & $\ldots$ & - \\
\hline 276 & 276 & -. & - & .. & - & -. \\
\hline 241 & 727 & 241 & - - & - & - & - \\
\hline 460 & 460 & 460 & 460 & - & -. & $f$ \\
\hline 490 & 490 & - - & - - & - - & - - & - \\
\hline 71 & 114 & 78 & -- & -. & -. & - \\
\hline 642 & 642 & - & - - & - & - - & - \\
\hline 332 & 615 & 330 & - & - & - - & -- \\
\hline 598 & 598 & 596 & 560 & - & - - & - \\
\hline 122 & 159 & 116 & 154 & - & -. & - \\
\hline
\end{tabular}


271856082295401 271857082285301 271859082164301 271907082315101 271910082343701

271917082304801 271922082241801 271922082340701 271931082233801 271932082313101

271937082321801 271937082322601 271938082305501 271942082315701 271943082315401

271958082175801 271959082270901 272002082342701 272006082322301 272009082302501

272009082324801 272010082352201 272015082285401 272018082374801 272019082322601

272019082354301 272020082194801 272021082353601 272023082354801 272030082260301

272030082260801 272031082292901 272032082250301 272040082325501 272040082325801

272045082325201 272047082273701 272047082291501 272048082295801 272049082325001
Forest Lake Golf Course

Early

Live Oak Ranch

Sarasota Hospital

City of Sarasota

J. A. Hooper

George Turner Ranch

Plymouth Harbour

Emerald Sod

Sarasota Junior High School

Orange Avenue

Selby

Meta Physical Church

Florasota

City of Sarasota

Lauck

E.M.R. Electronics

City of St. Petersburg

01d Campbe11 Plymouth

Sarasota County Fairgrounds

City of Sarasota

Longboat Key

Sicka

J. A. Cook

E11ie Book Store

Arvida Corporation

City of Sarasota

Longboat Utilities

Longboat Key Golf Course

Sun $\mathrm{N}^{\prime}$ Fun

Sun $N^{\prime}$ Fun

Irrigation

Cowart Ranch

City of Sarasota

City of Sarasota

City of Sarasota

Guest-Rellum Lane

City of Sarasota

U.S. Geological Survey

City of Sarasota
Sarasota

Sarasota

Sarasota

Sarasota

Sarasota

Sarasota

Sarasota

Sarasota

Sarasota

Sarasota

Sarasota

Sarasota

Sarasota

Sarasota

Sarasota

Sarasota

Sarasota

Sarasota

Sarasota

Sarasota

Sarasota

Sarasota

Sarasota

Sarasota

Sarasota

Sarasota

Sarasota

Sarasota

Sarasota

Sarasota

Sarasota

Sarasota

Sarasota

Sarasota

Sarasota

Sarasota

Sarasota

Sarasota

Sarasota

Sarasota
$12-63$

$1-83$

$3-65$

10-68

$12-79$

$3-62$

$1-72$

3-66

$3-62$

6- 68

$5-77$

$8-74$

$6-65$

5-82

5-66

3-65

7-78

3-83

7-81

$12-70$

7-80

5-69

$6-78$

4-62

3-78

8- 85

$12-78$

10-85

$1-72$

10-85

$10-85$

$5-62$

$3-72$

$3-80$

3- 80

7-81

$7-78$

4-81

8-66

$12-80$ 


\begin{tabular}{|c|c|c|c|c|c|c|}
\hline \multicolumn{7}{|c|}{$\begin{array}{l}\text { Type of } 10 g \text { and depth logged, } \\
\text { in feet below land-surface datum }\end{array}$} \\
\hline Electric & $\begin{array}{l}\text { Gamma- } \\
\text { ray }\end{array}$ & Caliper & $\begin{array}{c}\text { Fluid } \\
\text { conductivity }\end{array}$ & $\begin{array}{c}\text { Tempera- } \\
\text { ture }\end{array}$ & $\begin{array}{l}\text { Flow } \\
\text { meter }\end{array}$ & Other \\
\hline 583 & 583 & $\ldots$ & $\ldots$ & $\because$ & $\cdots$ & - \\
\hline-- & - & 250 & $\ldots$ & - & - & - \\
\hline 402 & 400 & - - & $\ldots$ & $\ldots$ & - - & - \\
\hline 489 & 593 & 489 & -- & $\ldots$ & - & - \\
\hline 397 & 400 & 364 & -- & - & -- & - \\
\hline 622 & 622 & $\ldots$ & - & - & - & - \\
\hline 383 & 687 & 383 & - & - - & - & - \\
\hline 132 & 354 & -. & - & $\ldots$ & - & - \\
\hline 691 & 691 & - & - & - & $\ldots$ & - \\
\hline 180 & 214 & 188 & - & - & - & - \\
\hline- & 571 & 571 & 572 & $\ldots$ & $\ldots$ & $\ldots$ \\
\hline 430 & 430 & $\ldots$ & - - & - - & - & - \\
\hline 501 & - - & 501 & 501 & - & - & - \\
\hline 625 & - - & - & - - & -- & $\cdots$ & - - \\
\hline 200 & 216 & $\cdots$ & - & - & $\cdots$ & - \\
\hline 421 & 421 & - & - & - & $\ldots$ & $\ldots$ \\
\hline 168 & 240 & 230 & - & - & $\ldots$ & - \\
\hline 300 & 303 & 302 & 277 & - - & $\ldots$ & - \\
\hline 620 & 620 & 620 & - & - & - & - - \\
\hline 500 & 537 & 500 & -- & -- & $\cdots$ & -- \\
\hline 353 & 610 & 410 & 332 & 392 & 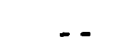 & - \\
\hline 499 & 499 & 499 & 499 & 499 & - & $\mathrm{f}$ \\
\hline 59 & 84 & 67 & 89 & -- & - & - \\
\hline 364 & 364 & -- & -- & -- & - & -- \\
\hline 321 & -- & 321 & -- & - & -- & -- \\
\hline 390 & 542 & 540 & 526 & 536 & $\cdots$ & - \\
\hline 358 & 489 & - & - & - & - & - \\
\hline 466 & 460 & $\ldots$ & - & - & $\ldots$ & $\ldots$ \\
\hline 242 & 542 & 242 & - & - & - . & - - \\
\hline 444 & -- & 444 & -- & -- & -- & -- \\
\hline 522 & 635 & 634 & 555 & 624 & $\ldots$ & $\ldots$ \\
\hline 622 & 622 & $\ldots$ & - & - & - & $\ldots$ \\
\hline 571 & 1,033 & 569 & - - & - & - & - \\
\hline 527 & - & 527 & 490 & - & $\ldots$ & -- \\
\hline 513 & 401 & 524 & -- & -- & - & - \\
\hline 334 & 350 & 347 & - & - & - & - \\
\hline 80 & 147 & 74 & 130 & - & - & - \\
\hline 584 & 608 & 608 & 578 & 592 & - & - \\
\hline - - & 36 & - & - & - & - & - \\
\hline 137 & - & 215 & -- & -- & - & -- \\
\hline
\end{tabular}


272050082325701 272051082275401 272052082325001 272054082293601 272058082143701

272059082290301 272059082325301 272102082324001 272104082321801 272104082326001

272105082363301 272108082320801 272113082330201 272119082330701 272120082322701

272120082322703 272121082363601 272122082330801 272122082330801 272123082330901

272124082292601 272126082275201 272127082323801 272128082200301 272128082301501

272129082330201 272133082324701 272142082371701 272142082371801 272151082151801

272151082310701 272153082373001 272156082372401 272158082370601 272158082372801

272202082282401 272203082165401 272203082322101 272210082200401 272213082154901
City of Sarasota

Cedar Hollow Subdivision

City of Sarasota

Paver Construction Company

City of Sarasota

City of St. Petersburg

Boys Bluff

Guthery We11

City of Sarasota

21-2

$21-5$

City of St. Petersburg

City of Sarasota

Webber

City of Sarasota

City of Sarasota Longboat Key Club City of Sarasota City of Sarasota

F. Richards

Kensington Park

Meadow's

City of Sarasota

Kaimee Ranch

\#12B

City of Sarasota

City of Sarasota

Far Horizons

Far Horizons

Verna Well Field

City of Sarasota

Longboat Key

Arvida \#3

Arvida \#2

Longboat Key

Andrews

Don D. Ranch

Wende11 Kent Company

Myakka Ranch

City of Sarasota

\begin{tabular}{|c|c|}
\hline Sarasota & $12-80$ \\
\hline Sarasota & $4-85$ \\
\hline Sarasota & $12-80$ \\
\hline Sarasota & $7-63$ \\
\hline Sarasota & $11-78$ \\
\hline Sarasota & $3-62$ \\
\hline Sarasota & $3-71$ \\
\hline Sarasota & $1-79$ \\
\hline Sarasota & $4-79$ \\
\hline Sarasota & $10-83$ \\
\hline Sarasota & $11-84$ \\
\hline Sarasota & $3-62$ \\
\hline Sarasota & $6-78$ \\
\hline Sarasota & $7-82$ \\
\hline Sarasota & $6-78$ \\
\hline Sarasota & $5-80$ \\
\hline Sarasota & $1-82$ \\
\hline Sarasota & $5-80$ \\
\hline Sarasota & $6-80$ \\
\hline Sarasota & $7-82$ \\
\hline Sarasota & $8-62$ \\
\hline Sarasota & \\
\hline Sarasota & $6-78$ \\
\hline Sarasota & $5-63$ \\
\hline Sarasota & $8-62$ \\
\hline Sarasota & $6-78$ \\
\hline Sarasota & $6-78$ \\
\hline Sarasota & $10-66$ \\
\hline Sarasota & $10-66$ \\
\hline Sarasota & $12-76$ \\
\hline Sarasota & $6-80$ \\
\hline Sarasota & $10-67$ \\
\hline Sarasota & $9-77$ \\
\hline Sarasota & $9-77$ \\
\hline Sarasota & $10-67$ \\
\hline Sarasota & $11-78$ \\
\hline Sarasota & $11-72$ \\
\hline Sarasota & $1-72$ \\
\hline Sarasota & $11-72$ \\
\hline Sarasota & $6-72$ \\
\hline
\end{tabular}


Type of $\log$ and depth logged, in feet below land-surface datum

\begin{tabular}{|c|c|c|c|c|c|c|}
\hline Electric & $\begin{array}{c}\text { Gamma- } \\
\text { ray }\end{array}$ & Caliper & $\begin{array}{c}\text { Fluid } \\
\text { conductivity }\end{array}$ & $\begin{array}{c}\text { Tempera- } \\
\text { ture }\end{array}$ & $\begin{array}{l}\text { Flow } \\
\text { meter }\end{array}$ & Other \\
\hline 54 & - & 96 & - & -- & - & - - \\
\hline 500 & 500 & 500 & - & - & - & $\ldots$ \\
\hline 64 & 120 & 116 & 82 & - &.- & - \\
\hline 707 & 707 & .. & $\ldots$ & - - & $\ldots$ & $\ldots$ \\
\hline 400 & 516 & - & -- & $\cdots$ & - & - \\
\hline 698 & 698 & - & $\ldots$ & $\ldots$ & -- & -- \\
\hline 447 & 447 & - & 447 & 447 & - & $\ldots$ \\
\hline 617 & 632 & 616 & 616 & 614 & - & -- \\
\hline 520 & 528 & 530 & -. & $\ldots$ & - & -- \\
\hline 430 & 430 & 430 & 430 & 430 & - & - \\
\hline 521 & $\ldots$ & 521 & 521 & 521 & - & - \\
\hline 268 & 268 & - & - & - & - - & - - \\
\hline 530 & 525 & 534 & 431 & - - & $\ldots$ & - \\
\hline 393 & - & 483 & - - & - & - & - \\
\hline 477 & 553 & 480 & 550 & $\ldots$ & $\ldots$ & -- \\
\hline 303 & 552 & 394 & 314 & $\ldots$ & $\ldots$ & - \\
\hline 136 & $\ldots$ & 136 & 156 & - - & $\ldots$ & - \\
\hline 490 & 704 & 794 & - & - - & - - & $\ldots$ \\
\hline 436 & 539 & 540 & 518 & - & - - & $\mathrm{f}$ \\
\hline 450 & - - & 462 & -. & - & - & -- \\
\hline 162 & 162 & - & - - & - & - & - \\
\hline 321 & - & 312 & 321 & - & $\ldots$ & - \\
\hline 642 & 639 & 444 & 642 & $\ldots$ & -. & $\ldots$ \\
\hline 1,494 & -. & - & - & $\ldots$ & $\ldots$ & $\ldots$ \\
\hline 106 & 106 & - & - & - & $\ldots$ & - \\
\hline 578 & 577 & 572 & $\ldots$ & - & $\ldots$ & $\ldots$ \\
\hline 335 & 337 & 333 & 339 & $\ldots$ & - - & - - \\
\hline 295 & 525 & - - & - & - - & - - & - - \\
\hline - & 162 & $\ldots$ & - & - - & - & - - \\
\hline 639 & 635 & 632 & 553 & 520 & -- & - \\
\hline 638 & 670 & 650 & $\ldots$ & $\ldots$ & - & $\ldots$ \\
\hline 230 & - & -. & $\ldots$ & $\ldots$ & - . & $\ldots$ \\
\hline 330 & 331 & 335 & - & - & - & - \\
\hline 316 & 320 & -. & - & - & $\ldots$ & $\ldots$ \\
\hline 190 & 250 & 250 & 250 & - & - - & - \\
\hline 428 & 700 & 436 & -- & - & - & - \\
\hline 549 & 1,006 & 546 & $\ldots$ & $\ldots$ & - & $\ldots$ \\
\hline 148 & 196 & 197 & $\ldots$ & - & $\ldots$ & -. \\
\hline 763 & 888 & 750 & - & - - & - & - - \\
\hline 429 & 599 & 426 & - & -- & - & - \\
\hline
\end{tabular}


272219082151701 272221082300801 272221082320301 272222082283201 272228082333401

272233082151101 272237082331601 272242082235501 272248082162801 272248082170101

272248082170201 272248082171901 272248082173601 272248082175201 272248082175301

272248082182701 272248082184501 272248082184601 272248082190201 272249082182601

272249082373301 272254082234901 272254082332801 272255082172201 272255082180201

272256082175901 272256082321701 272257082162801 272257082165401 272257082171101

272257082172901 272257082174401 272257082181601 272257082181801 272257082183501

272257082183601 272257082185301 272257082185401 272257082333701 272301082191401
City of Sarasota

Lake Iola Grove

North Gate Industrial Park

Horace Sutcliffe

Sapphire Heights

City of Sarasota

Days Inn Motel, North Trail

Manatee Schroeder

City of Sarasota

City of Sarasota

City of Sarasota

City of Sarasota

City of Sarasota

City of Sarasota

City of Sarasota

City of Sarasota

City of Sarasota

City of Sarasota

City of Sarasota

City of Sarasota

Arvida \#1

Manatee Schroeder

Ringling Museum

City of Sarasota

City of Sarasota

City of Sarasota

Mobile Life Corporation

City of Sarasota

City of Sarasota

City of Sarasota

City of Sarasota

City of Sarasota

City of Sarasota

City of Sarasota

City of Sarasota

City of Sarasota

City of Sarasota

City of Sarasota

City of Sarasota

City of Sarasota

$\begin{array}{lr}\text { Sarasota } & 4-79 \\ \text { Sarasota } & 5-65 \\ \text { Sarasota } & 6-80 \\ \text { Sarasota } & 11-78 \\ \text { Sarasota } & 3-62 \\ & \\ \text { Sarasota } & 10-83 \\ \text { Sarasota } & 11-78 \\ \text { Sarasota } & 7-76 \\ \text { Sarasota } & 4-79 \\ \text { Sarasota } & 12-71 \\ & \\ \text { Sarasota } & 4-80 \\ \text { Sarasota } & 1-66 \\ \text { Sarasota } & 4-80 \\ \text { Sarasota } & 7-71 \\ \text { Sarasota } & 11-65 \\ & \\ \text { Sarasota } & 5-86 \\ \text { Sarasota } & 1-72 \\ \text { Sarasota } & 2-66 \\ \text { Sarasota } & 12-71 \\ \text { Sarasota } & 12-71 \\ \text { Sarasota } & 9-77 \\ \text { Sarasota } & 7-76 \\ \text { Sarasota } & 10-64 \\ \text { Sarasota } & 2-65 \\ \text { Sarasota } & 12-71 \\ \text { Sarasota } & 11-78 \\ \text { Sarasota } & 10-64 \\ \text { Sarasota } & 4-79 \\ \text { Sarasota } & 4-81 \\ \text { Sarasota } & 3-81 \\ \text { Sarasota } & 1-72 \\ \text { Sarasota } & 1-66 \\ \text { Sarasota } & 1-72 \\ \text { Sarasota } & 1-66 \\ \text { Sarasota } & 12-71 \\ \text { Sarasota } & 8-84 \\ \text { Sarasota } & 1-72 \\ \text { Sarasota } & 5-80 \\ \text { Sarasota } & 11-83 \\ \text { Sarasota } & 4-81 \\ \text { Sarota } & \end{array}$




\begin{tabular}{|c|c|c|c|c|c|c|}
\hline \multicolumn{7}{|c|}{$\begin{array}{l}\text { Type of log and depth logged, } \\
\text { in feet below land-surface datum }\end{array}$} \\
\hline Electric & $\begin{array}{l}\text { Gamma- } \\
\text { ray }\end{array}$ & Caliper & $\begin{array}{c}\text { Fluid } \\
\text { conductivity }\end{array}$ & $\begin{array}{l}\text { Tempera- } \\
\text { ture }\end{array}$ & $\begin{array}{l}\text { Flow } \\
\text { meter }\end{array}$ & Other \\
\hline 591 & 712 & 610 & 584 & -- & - - & - - \\
\hline 350 & - - & -- & -- & - - & -- & -- \\
\hline 556 & 554 & 554 & - - & -- & -- & -- \\
\hline 16 & 126 & 16 & -- & -- & -- & - - \\
\hline 488 & 488 & - - & - - & -- & - - & - - \\
\hline 470 & 596 & 450 & 480 & - & -- & - \\
\hline 342 & 375 & 356 & 358 & - - & - - & - - \\
\hline 967 & 1,368 & 1,358 & -- & -- & -- & -- \\
\hline 369 & 476 & 370 & - & -- & -- & -- \\
\hline 69 & 121 & 68 & -- & -- & -- & -- \\
\hline 369 & 502 & 448 & 383 & -- & -- & -- \\
\hline 494 & 493 & -- & -- & -- & -- & -- \\
\hline 355 & 473 & 456 & 356 & - - & -- & - - \\
\hline 34 & - - & - - & - - & -- & - - & -- \\
\hline-- & 484 & 479 & 484 & -- & -- & -- \\
\hline 474 & 603 & 476 & 478 & 530 & - - & - - \\
\hline- & 74 & -- & -- & - - & -- & -- \\
\hline 376 & - & -- & - & -- & - & - - \\
\hline 52 & 138 & 50 & -- & -- & -- & - - \\
\hline - - & 107 & - - & -- & -- & -- & -- \\
\hline 155 & 155 & 155 & -- & - - & -- & - - \\
\hline 880 & -- & -- & -- & -- & - - & -- \\
\hline 320 & 320 & -- & -- & - - & -- & - - \\
\hline 700 & - & -- & 700 & -- & - - & -- \\
\hline 11 & 122 & 131 & -- & -- & -- & -- \\
\hline 357 & 496 & -- & -- & -- & - - & - - \\
\hline 536 & 536 & - - & - & -- & -- & -- \\
\hline 313 & 451 & 366 & 334 & 330 & - & - - \\
\hline 356 & 470 & 393 & 432 & -- & -- & - - \\
\hline 356 & 500 & 400 & 392 & -- & -- & -- \\
\hline 29 & 83 & 26 & -- & -- & - & -- \\
\hline 468 & 468 & 464 & 470 & -- & -- & -- \\
\hline 20 & 102 & 20 & -- & - - & - - & - - \\
\hline 478 & -- & -- & 478 & - - & - - & -- \\
\hline 10 & 93 & 10 & -- & -- & -- & -- \\
\hline 482 & 609 & 512 & - - & 560 & -- & -- \\
\hline-- & 103 & -- & - - & -- & -- & - - \\
\hline 476 & 606 & 478 & 490 & - - & -- & -- \\
\hline 550 & 543 & 548 & -- & -- & -- & - - \\
\hline 526 & 734 & 734 & 550 & 854 & -- & - - \\
\hline
\end{tabular}


272305082190201

272305082190301

272306082182601

272306082182701

272306082184501

272306082184601

272307082164501

272307082170201

272307082171701

272307082171801

272307082173701

272307082173801

272307082180801

272307082180901

272307082182701

272308082175301

272310082200401

272313082320801

272317082285901

272317082291901

272317082294401

272317082295201

272317082295801

272317082295802

272317082300901

272317082302401

272317082331501

272318082302301

272344082314201

272357082181301

272403082312101

272703082165401

275652082185801

275927082193201
City of Sarasota

City of Sarasota

City of Sarasota

City of Sarasota

City of Sarasota

City of Sarasota

City of Sarasota

City of Sarasota

City of Sarasota

City of Sarasota

City of Sarasota

City of Sarasota

City of Sarasota

City of Sarasota

City of Sarasota

City of Sarasota

Myakka Ranch

Montgomery Ward

Sarasota County

Sarasota County

Sarasota County

Sarasota County Utilities

Sarasota County

Sarasota County

Sarasota County

Sarasota County

Sarasota Manatee Airport

Sarasota County

Midway Groves

U.S. Geological Survey

Blaser's \#2

Don N. Ranch

Englewood

Englewood Water District
Sarasota

$7-71$

Sarasota

$1-66$

Sarasota

Sarasota

Sarasota

Sarasota

Sarasota

Sarasota

Sarasota

Sarasota

Sarasota

Sarasota

Sarasota

Sarasota

Sarasota

Sarasota

Sarasota

Sarasota

Sarasota

Sarasota

Sarasota

Sarasota

Sarasota

Sarasota

Sarasota

Sarasota

Sarasota

Sarasota

Sarasota

Sarasota

Sarasota

Sarasota

Sarasota

Sarasota
$12-71$

5- 80

1-72

4- 79

$11-65$

$1-66$

1-72

5-80

2- 81

$2-72$

$1-72$

1-66

1- 66

1-66

$11-72$

10-64

7-85

$11-85$

3- 86

$5-86$

$7-85$

$7-85$

1-86

10-82

$10-64$

3-83

$2-77$

$10-66$

10-73

$11-72$

$2-76$

7-76 


\begin{tabular}{|c|c|c|c|c|c|c|}
\hline \multicolumn{7}{|c|}{$\begin{array}{l}\text { Type of } \log \text { and depth logged, } \\
\text { in feet below land-surface datum }\end{array}$} \\
\hline Electric & $\begin{array}{l}\text { Gamma- } \\
\text { ray }\end{array}$ & Caliper & $\begin{array}{c}\text { Fluid } \\
\text { conductivity }\end{array}$ & $\begin{array}{c}\text { Tempera- } \\
\text { ture }\end{array}$ & $\begin{array}{l}\text { Flow } \\
\text { meter }\end{array}$ & Other \\
\hline- & 71 & - & - & - & $\ldots$ & - \\
\hline 498 & 498 & - & - & $\ldots$ & $\ldots$ & $\ldots$ \\
\hline - - & 88 & - & - & - & $\cdots$ & $\cdots$ \\
\hline 364 & 498 & 385 & 380 & - & $\ldots$ & $\ldots$ \\
\hline- & 88 & - & $\ldots$ & -. & - & -. \\
\hline 418 & 537 & 421 & 414 & - & - & $-\cdots$ \\
\hline 404 & 404 & 392 & - & $\ldots$ & $\ldots$ & $\ldots$ \\
\hline 400 & 400 & 394 & $\ldots$ & $\ldots$ & $\ldots$ & $\ldots$ \\
\hline 85 & 124 & - & $\ldots$ & $\ldots$ & $\ldots$ & $\ldots$ \\
\hline 356 & 486 & 362 & - - & $\ldots$ & $\ldots$ & - \\
\hline 364 & - & 476 & 397 & $\ldots$ & $\ldots$ & $\ldots$ \\
\hline 41 & 124 & 39 & $\ldots$ & - & - & - \\
\hline 54 & 126 & 39 & - & $\cdots$ & - & - \\
\hline 470 & 470 & - & - - & - & - & - - \\
\hline 476 & 476 & -- & -- & - & - & - \\
\hline 517 & 517 & 457 & 517 & $\ldots$ & $\ldots$ & $\ldots$ \\
\hline 763 & 888 & 750 & - & - - & - & - \\
\hline 382 & 382 & - - & - & - & - & - \\
\hline - - & 525 & 522 & 511 & 526 & $\ldots$ & - \\
\hline 263 & 637 & 275 & 259 & 629 & - & -- \\
\hline 358 & 600 & 570 & - - & - & -. & - \\
\hline 182 & 578 & 190 & 182 & 576 & - & - \\
\hline 347 & 381 & 381 & - & - & $\cdots$ & $\ldots$ \\
\hline - & 525 & 522 & 511 & 526 & - & . \\
\hline 264 & 574 & 210 & -- & 570 & - & - \\
\hline 341 & 341 & - - & 567 & 560 & $\ldots$ & - \\
\hline 99 & - - & - & - & - - & - & - \\
\hline 286 & 602 & 603 & 385 & 508 & - & - \\
\hline 186 & 218 & 204 & 217 & - - & - & - \\
\hline 450 & 435 & -- & -- & $\cdots$ & - & - \\
\hline 638 & 630 & 630 & - & -- & $\ldots$ & $\cdots$ \\
\hline 543 & 1,006 & 546 & - & - & $\ldots$ & . \\
\hline - & - & 92 & - & $\cdots$ & $\ldots$ & - \\
\hline 68 & 106 & 69 & - & - & - & - \\
\hline
\end{tabular}

